\title{
Constitutional Theory in a Nutshell
}

Thomas E. Baker

Florida International University College of Law

Follow this and additional works at: https://ecollections.law.fiu.edu/faculty_publications

Part of the Constitutional Law Commons

\section{Recommended Citation}

Thomas E. Baker, Constitutional Theory in a Nutshell , 13 Wm. \& Mary Bill Rts. J. 57 (2004).

Available at: https://ecollections.law.fiu.edu/faculty_publications/128 


\section{William \& Mary Bill of Rights Journal}

Volume 13 | Issue 1

Article 3

\section{Constitutional Theory in a Nutshell}

Thomas E. Baker

\section{Repository Citation}

Thomas E. Baker, Constitutional Theory in a Nutshell, 13 Wm. \& Mary Bill Rts. J. 57 (2004), http://scholarship.law.wm.edu/wmborj/vol13/iss1/3

Copyright c 2004 by the authors. This article is brought to you by the William \& Mary Law School Scholarship Repository. 


\title{
CONSTITUTIONAL THEORY IN A NUTSHELL
}

\author{
Thomas E. Baker*
}

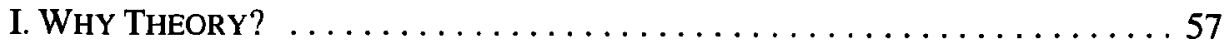

II. WHO INTERPRETS THE CONSTITUTION? . . . . . . . . . . . . . 60

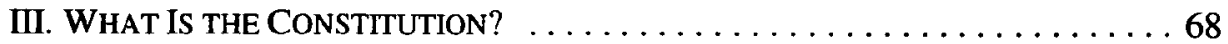

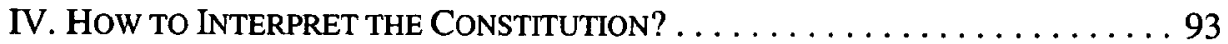

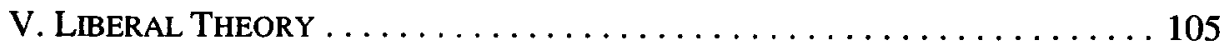

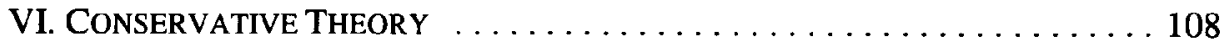

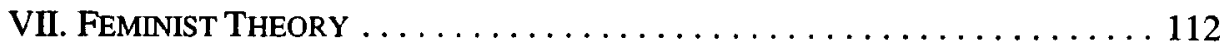

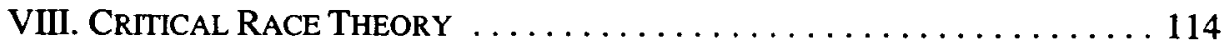

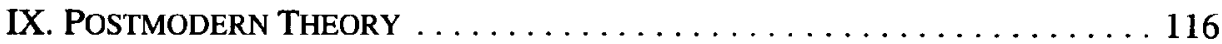

X. DOES THEORY MATTER? . . . . . . . . . . . . . . . . . . . . . . 118

The ubiquitous and popular West Nutshell Series promises to deliver in each and every volume "a succinct exposition of the law to which a student or lawyer can turn for reliable guidance" published in "a compact format for convenient reference." That is the purpose and function of this article: to provide the intelligent novice a beginner's guide to the considerable body of scholarly writings about the theory of American constitutional law.

\section{WHY THEORY?}

Why not? Sorry, it is a professor's habit to answer a question with a question. But then again, this article is all about trying to make some sense of a peculiar dialect of legalese that might be called "con law prof talk," which you will encounter in class discussions or out-of-class readings in treatises and law reviews.

* Member of the Founding Faculty, Florida International University College of Law, Miami, Florida; thomas.baker@fiu.edu. This article is adapted with permission from Thomas E. BaKer \& Jerre S. Williams, Constitutional ANALYSIS IN A NuTSHell (2d ed. 2003) [hereinafter BAKER \& WILLIAMS]. I have made an effort to preserve the style and voice of a useful student aide, however, as opposed to the typical law review article particularly the typical law review article about legal theory. I want to thank three colleagues - three leading constitutionalists - for reviewing and commenting on the earlier manuscript: Erwin Chemerinsky, Alston \& Bird Professor, Duke University Law School; Michael J. Gerhardt, Arthur B. Hanson Professor of Constitutional Law, MarshallWythe School of Law, College of William \& Mary; and Thomas D. Rowe, Jr., Elvin R. Latty Professor, Duke University School of Law.

I BAKER \& WiLliams, supra note *, at back cover. There are 123 separate titles in the series covering the entire law school curriculum. See http://lawschool.westlaw.com/studyaids/nutshell.asp?lhot=y\&mainpage $=11 \&$ subpage $=3$. 
When your professor mentions or you read references to "neutral principles" or "originalism" or "constitutional moments" or "countermajoritarian difficulty" or "civic republicanism" or "hermeneutics" or "illegitimate hierarchies" or "social constructs" or "anti-essentialism" or "postmodern epistemology," do you have a clue? You definitely need to get one, if you go to a fancy law school or if your professor did - and that would include just about every law student in the United States. This article will help. ${ }^{2}$

Constitutional law is a challenging subject to master for several reasons. ${ }^{3}$ First, it is so important, and has been so instrumental in shaping our nation's history. Second, while it is an American invention, as a nation we have been reinventing constitutional law over the last two centuries. Third, the Supreme Court of the United States is an inscrutably fascinating institution made up of an odd cast of characters. Fourth, there is so much material when we contemplate over five hundred Talmudic volumes of United States Reports filled with majority, concurring, and dissenting opinions, which are augmented by an endless scholarly commentary. Fifth, each October Term there are new decisions that elaborate, revise, and sometimes overrule our past understandings. Sixth, constitutional law resembles a kind of civic religion that has transcendent and immanent qualities for our national political life. This is tough law, tough to teach, tough to learn, and tough to master. ${ }^{4}$

Constitutional theory helps us to overcome this difficulty and master our subject. It helps us to understand Supreme Court decisions and helps us to cope with the elaborate and often conflicting opinions of the Justices. It allows us to

${ }^{2}$ Without further or more particular attribution beyond this passim reference, I acknowledge the intellectual debt of borrowing heavily from three textbooks for the organization, the themes, and some of the content of this article: JOHN H. GARVEY ET AL., MODERn CONSTitutional Theory: A ReAder (5th ed. 2004); MiCHAEL J. GERHARDT ET

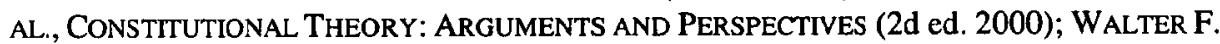
MURPHY ET AL., AMERICAN CONSTITUTIONAL INTERPRETATION (3d ed. 2003). Most of the articles referenced in this article are excerpted in the first two texts. These three texts are widely-used, and I have used them in my own teaching of the basic course and elective courses. If my reader wants to pursue the subject beyond this article, these three books will take you a long way toward understanding constitutional theory and philosophy, and they also contain extensive reading lists. See generally THOMAS E. BAKER, "THE MOST WONDERFUL WORK ...": OUR CONSTITUTION INTERPRETED (1996); ERWIN CHEMERINSKY, Constitutional Law: PRINCIPLES ANd Policies $\$ \S 1.4-5$ (2d ed. 2002); Ronald D. Rotunda \& John E. NOWAK, TREatise on Constitutional LaW: Substance \& Procedure $§ 23$ (3d ed. 1999); 1 LaURENCE H. Tribe, AMerican Constitutional Law \$§ 1-1 to 1-21 (3d ed. 2000).

3 See generally Thomas E. Baker, Mastering Constitutional Law, 21 SEATTLEU.L. ReV. 927, 927-28 (1998); Richard S. Kay, Constitutional Cultures: Constitutional Law, 57 U.CHI. L. REv. 311, 311-12 (1990) (book review).

4 "This prepares us for the remark that taught law is tough law." FREDERICK WILLAM MATtLAND, ENGLISH LAW AND THE RENAISSANCE 18 (1901). 
distinguish between a good argument and a bad argument. Constitutional theory helps us to understand where an argument is coming from and where it might take us. It helps us to see the big picture. We better understand how a doctrine came to be and how it might evolve. We see how different doctrines are related and how they fit into the overall organization of constitutional law. Constitutional theory allows us to talk about our subject with each other. It is the patois that constitutional law professors write and speak to other professors and to their students. Thus, if we manage to gain some perspective from the vantage of constitutional theory, we will better understand constitutional law. At least, that is what a con law prof would tell you while sober.

This article provides a nutshell description of the leading theories and identifies some of the leading theorists on the Constitution. The unit of currency here is the academic law review article, not the Supreme Court decision. ${ }^{5}$ The citations here provide illustrative examples of the vast body of literature. ${ }^{6}$ The discussion provides preliminary sketches of an intellectual landscape that is vast and often foreboding to the beginner. An introductory note of caution should be sounded: these theories are neither self-contained nor static. Rather, they overlap over time and they are evolving in different directions. They are plastic, and therefore highly contestable, and hotly-contested.

For example, Scott D. Gerber, at Ohio Northern, has demonstrated that each and every one of the extant methods of constitutional interpretation can be shown to recognize a right of privacy and, at the same time, all of them can be shown to deny it. He concludes that scholars and jurists too often prefer outcomes to theory. ${ }^{7}$ Indeed, one of the worst raps against theory qua theory is that interpreters really only make up their minds about a set of particular key issues that are important to them, such as abortion, affirmative action, and the death penalty, and only then pretend to be committed to some larger theory of the Constitution. This criticism

${ }^{s}$ For a convenient and thorough annual review of the Supreme Court's decisions, see generally the November issues of the Harvard Law Review, which provide case summaries and analysis plus detailed statistics for each preceding October Term. The Supreme Court's official homepage is at http://www.supremecourtus.gov/ but the two best Internet blogs on the Supreme Court are How Appealing at http://appellateblog.blogspot.com, and SCOTUSblog at http://www.goldsteinhowe.com/blog/. The best practice book on Supreme Court procedures is ROBERT L. STERN ET AL., SUPREME COURT PRACTICE (8th ed. 2002).

6 Susan low Bloch \& Thomas G. Krattenmaker, Supreme Court Poltitcs: The InSTTTUTION AND ITS PROCEDURES (1994); A CONSTITUTIONAL ANTHOLOGY (Michael J. Glennon et al. eds., 2d ed. 1997); PhILIP CoOper \& Howard BaLl, The United STATES SUPREME COURT: FROM THE INSIDE OUT (1996); GARVEY, supra note 2; GERHARDT, supra note 2; THE SUPREME COURT IN AMERICAN SOCIETY: EQUAL JUSTICE UNDER LAW (Kermit L. Hall ed., 2001); Thomas E. Baker, A Constitutional Bibliography, 5 WM. \& MARY BILL RTS. J. 277 (1996).

7 Scott D. Gerber, Privacy and Constitutional Theory, 17 Soc. PHIL. \& PoL'y 165 (2000). 
of theorizing goes for professors and Justices alike. "The single most important word in modern constitutional theory is "interpretation," "according to Paul Campos, at the University of Colorado, but " $[t]$ he single most confusing word in modern constitutional theory is "interpretation.",

This article is organized around three basic interpretative questions: ${ }^{9}$ Who has the authority to interpret the Constitution? What are the legitimate sources of meaning for interpreting the Constitution? How is the Constitution interpreted within different theoretical approaches? The discussion then briefly identifies some of the basic tenets of the prominent contemporary schools of legal philosophy about the Constitution: ${ }^{10}$ liberal theory; conservative theory; feminist theory; critical race theory; and postmodern theory. Finally, a somewhat self-consciously introspective conclusion will ask rhetorically: Does theory matter? (The answer is another fauxZen bit of con law prof talk: it depends.)

\section{WHO INTERPRETS THE CONSTITUTION?}

Of course, the traditional first year law school answer is the Supreme Court of the United States - that is what we make of Chief Justice Marshall's 1803 opinion in Marbury v. Madison, ${ }^{11}$ at least. ${ }^{12}$ But that is a rather incomplete answer, when

8 Paul Campos, Three Mistakes About Interpretation, 92 MiCH. L. REV. 388 (1993). See generally Philip Bobbitt, Constitutional Interpretation, in THE OXFORD COMPANION TO THE SuPREME COURT OF THE UNITED STATES 183 (Kermit L. Hall et al. eds., 1992) ("Constitutional Interpretation is both the process by which the American Constitution is construed and the study of that process."); Paul Brest, Constitutional Interpretation, in 2 ENCYCLOPEDIA OF THE AMERICAN CONSTITUTION (Leonard W. Levy \& Kenneth L. Karst eds., 2d ed. 2000) [hereinafter ENCYCLOPEDIA] ("'Constitutional interpretation' comprehends the methods or strategies available to people attempting to resolve disputes about the meaning or application of the Constitution.").

9 See generally MURPHY, supra note 2. One could imagine a fourth question of "When?" but it would depend more or less on the "Who?" and the "How?" questions. See Frederick Schauer, The Occasions of Constitutional Interpretation, 72 B.U. L. REV. 729 (1992). See also generally MURPHY ET AL., supra note 2, at 1583-92.

10 See generally GERHARDT, supra note 2.

115 U.S. (1 Cranch) 137 (1803).

12 "The study of constitutional law not only begins with [Marbury], it ends there as well. :.. [N] course in constitutional law ever gets beyond Marbury." PAUL W. KAHN, THE REIGN OF LAW: MARBURY V. MADISON AND THE CONSTRUCTION OF AMERICA 4 (1997). The best single treatment of Marbury v. Madison is William W. Van Alstyne, A Critical Guide to Marbury v. Madison, 1969 DUKE L.J. 1. See also Susan Low Bloch, The Marbury Mystery: Why Did William Marbury Sue in the Supreme Court?, 18 CONST. COMMENT. 607 (2001); Richard H. Fallon, Jr., Marbury and the Constitutional Mind: A Bicentennial Essay on the Wages of Doctrinal Tension, 91 CAL. L. REV. 1 (2003); David F. Forte, Marbury's Travail: Federalist Politics and William Marbury's Appointment as Justice of the Peace, 45 CATH. U.L. REV. 349 (1996); Michael J. Glennon, The Case that Made the Court, 27 
you think about it. The President takes an oath to "preserve, protect and defend the Constitution." 13 Members of Congress likewise must take an oath "to support this Constitution," as do members of all three branches of the state governments. ${ }^{14}$ Thus, federal and state officials are the first line of interpreters of the Constitution in the proper exercise of their governmental powers. ${ }^{15}$

Logically, the theory of judicial review does not necessarily require judicial supremacy. Within the national government of separated powers, there have been historical claims on constitutional supremacy made by all three branches. Chief Justice Marshall so feared the threat of judicial impeachments from the Jefferson Administration that he privately admitted that he would prefer a legislative power in Congress to set aside Supreme Court decisions. ${ }^{16}$ But that would have required a constitutional amendment. Although there are commentators from the left and the right who advocate that very idea today, ${ }^{17}$ the foundational principles of American constitutionalism simply would not allow Congress the last word on constitutional matters - doing so would undo the hierarchy of the written Constitution that renders the will of the people expressed in the organic document supreme over the will of the people's elected representatives expressed in legislation. ${ }^{18}$ This highlights the paradoxical, if not outright anti-democratic, nature of judicial review by which a simple majority ${ }^{19}$ of a committee of nine unelected lawyers with lifetime tenure exercises the power to invalidate what the people's duly-elected representatives in the national legislature have done following the formal procedures of majoritarian politics. Much of constitutional theorizing tries to overcome this "countermajoritarian difficulty" - as it is called in the constitutional jargon.

WILSON Q. 20 (2003); Donald F. Melhorn, Jr., A Moot Court Exercise: Debating Judicial Review Prior to Marbury v. Madison, 12 ConST. CoMMENT. 327 (1995); James M. O'Fallon, Marbury, 44 STAN. L. REv. 219 (1992); Judicial Review: Blessing or Curse? or Both? A Symposium in Commemoration of the Bicentennial of Marbury v. Madison, 38 WAKE FOREST L. REV. 313 (2003) [hereinafter Judicial Review]. See generally BAKER \& WLLIAMS, supra note *, at 53-91.

${ }^{13}$ U.S. ConST. art. II, \& 1, cl. 7.

${ }_{14}$ U.S. ConsT. art. VI, \& 1, cl. 3.

is See Louis Fisher \& Neal Devins, Political Dynamics of Constitutional Law (3d ed. 2001); Keith E. Whittington, Extrajudicial Constitutional Interpretation: Three Objections and Responses, 80 N.C. L. REV. 773 (2002).

${ }_{16}$ Michael J. Klarman, How Great Were the "Great" Marshall Court Decisions?, 87 VA.

L. REV. 1111, 1167-69 (2001).

17 See infra text accompanying notes 50-54.

18 See BAKER \& WILLIAMS, supra note $*$, at $1-52$.

19 For a tentative exploration of the idea to impose a supermajority voting requirement on the Justices themselves, see generally Evan H. Caminker, Thayerian Deference To Congress and Supreme Court Supermajority Rule: Lessons from the Past, 78 IND. L.J. 73 (2003). 
Congress is continually obliged to assess the constitutionality of its legislative actions. ${ }^{20}$ Implicit in every act of legislation is a congressional determination that the statute fits within one of its enumerated, delegated powers. Indeed, a perennial proposal that never ends up getting enacted would formally and explicitly impose this requirement on Congress, i.e., every federal statute would need to contain a concise and definite reference to the constitutional provision being relied on to enact the statute. ${ }^{21}$ Under the Necessary and Proper Clause in Article I, and for several other important clauses of the Constitution, however, the Supreme Court has adopted a decidedly deferential posture toward Congress's legislative policy judgments. This was the major premise of Chief Justice Marshall's landmark opinion for the Supreme Court in McCulloch v. Maryland. ${ }^{22}$ In this fashion, constitutional interpretation is a dynamic process resembling a conversation among the branches. ${ }^{23}$

${ }^{20}$ See generally Neal Kumar Katyal, Legislative Constitutional Interpretation, 50 DUKE L.J. 1335 (2001); Richard W. Murphy, Separation of Powers and the Horizontal Force of Precedent, 78 NOTRE DAME L. REV. 1075 (2003); Victoria Nourse, The Vertical Separation of Powers, 49 DUkE L.J. 749 (1999); V.F. Nourse, Toward a New Constitutional Anatomy, 56 STAN. L. REV. 835 (2004).

21 See, e.g., Enumerated Powers Act, H.R. 384, 108th Cong. (1st Sess. 2003). The requirement itself would be enacted under the clause authorizing each House to determine its own rules of procedure, U.S. ConST. art. I, $\S 5$, cl. 2, plus the Necessary and Proper Clause, id. § 8, cl. 18. See David P. Currie, The Smithsonian, 70 U. CHI. L. REV. 65 (2003).

${ }^{22} 17$ U.S. (4 Wheat.) 316 (1819). See BAKER \& WILLIAMS, supra note *, at 195-245. There are some interesting tensions between the vision of the Constitution revealed in Marbury v. Madison and McCulloch v. Maryland. Sylvia Snowiss, Text and Principle in John Marshall's Constitutional Law: the Cases of Marbury and McCulloch, 33 J. MARSHALL L. REV. 973 (2000). For an account of the story behind the case, see generally Bray Hammond, The Bank Cases, in QUARRELS THAT HAVESHAPED THE CONSTITUTION 37 (John A. Garraty ed., rev. ed. 1987). Chief Justice Marshall himself deemed the decision so important that he defended it by writing editorials, published under a pseudonym, explaining the decision and answering its critics. JOHN MARSHALL'S DEFENSE OF MCCULLOCH V. MARYLAND (Gerald Gunther ed., 1969).

23 By debating our deepest differences in the shared language of constitutional rights and responsibilities and in the terms of an enacted constitutional text, we encourage the possibility of persuasion and even moral education in our national life - looking not toward any one, permanent reconciliation of conflicting impulses but toward a judicially modulated struggle that changes shape but never ends.

Although the non-judicial branches, too, are sworn to uphold the Constitution, the independent judiciary has a unique capacity and commitment to engage in constitutional discourse - to explain and to justify its conclusions about governmental authority in a dialogue with those who read the same Constitution even if they reach a different view.

1 TRBE, supra note 2, $\S 1-9$, at 27. See generally Barry Friedman, Dialogue and Judicial Review, 91 MiCH. L. REV. 577 (1993); Robert C. Post, Fashioning the Legal Constitution: Culture, Courts, and Law, 117 HARV. L. REv. 4 (2003). 
It is up to the Supreme Court to have the final say, however, when Congress has exceeded its powers of constitutional interpretation. A few years ago, for example, when Congress passed a statute to get around a particular Supreme Court ruling by trying to provide greater legislative protection for religious liberty than the Justices had interpreted in the First Amendment, ${ }^{24}$ the Supreme Court, rather unceremoniously, struck down the federal statute. ${ }^{25}$ The Court held that Congress was not "enforcing" the Fourteenth Amendment; rather, the Court concluded that Congress was creating new rights or expanding existing rights in a way the Constitution would not allow - by invading the province of the judicial branch.

Numerous presidents have had occasion to assert coequal status with the other branches in their power to interpret the Constitution during showdowns between the Executive and Congress or the Supreme Court. ${ }^{26}$ Thomas Jefferson followed his own counsel on the constitutional issues in his position as chief prosecutor in the treason trial of Aaron Burr. ${ }^{27}$ Andrew Jackson deemed himself the tribune of the people and vetoed the bill to continue the Bank of the United States for the announced reason that it was unconstitutional, despite the fact that the Supreme Court had previously upheld its validity in the celebrated and previously-highlighted decision in McCulloch v. Maryland. ${ }^{28}$ Abraham Lincoln never accepted the infamous decision that placed the Supreme Court's constitutional imprimatur on slavery in Dred Scott $v$. Sanford, ${ }^{29}$ and he openly defied Chief Justice Taney's subsequent ruling that he lacked the power to suspend the writ of habeas corpus during the Civil War. ${ }^{30}$ Franklin D. Roosevelt challenged the Supreme Court by proposing to increase the number of Justices in his 1937 "Court-packing Plan," but Congress would not go along; tensions eased when the Justices seemed to lose some of their zeal for invalidating his programs around the same time, and eventually he would succeed in packing the Court the old-fashioned way - through retirements

24 Employment Division v. Smith, 494 U.S. 872 (1990).

25 City of Boerne v. Flores, 521 U.S. 507 (1997).

${ }^{26}$ See generally RoBert A. BURT, The CONSTITUTION IN CONFLICT (1992); Scott E. Gant, Judicial Supremacy and Nonjudicial Interpretation of the Constitution, 24 HASTINGS ConST.L.Q. 359 (1997); Michel Rosenfeld, Executive Autonomy, Judicial Authority and the Rule of Law: Reflections on Constitutional Interpretation and the Separation of Powers, 15 CARDOZO L. REV. 137 (1993).

${ }^{27}$ See United States v. Burr, 25 F. Cas. 2 (C.C.D. Va. 1807) (No. 14,692a). See generally DanielD. Blinka, "This GermofRottedness": FederalTrials in the NewRepublic, 1789-1807, 36 CREIGHTON L. REV. 135 (2003).

28 See generally Gerard N. Magliocca, Veto! The Jacksonian Revolution in Constitutional Law, 78 NEB. L. REV. 205 (1999).

2960 U.S. (19 How.) 393 (1865). See generally DON E. FEHRENBACHER, THE DRED SCOTT CASE: ITS SIGNIFICANCE IN AMERICAN LAW AND POLITICS (1978).

${ }^{30}$ Ex parte Merryman, 17 Fed. Cas. 144 (C.C.D. Md. 1861) (No. 9487). See generally Michael Stokes Paulsen, The Merryman Power and the Dilemma of Autonomous Executive Branch Interpretation, 15 CARDOZO L. REV. 81 (1993). 
and replacements. ${ }^{31}$ There have been equally historic occasions, however, when the President has acquiesced in judicial supremacy at the cost of a great loss of executive power, such as when President Truman gave back the steel mills he had nationalized during the Korean conflict, ${ }^{32}$ or when President Nixon obeyed the court order to turn over tape recordings of his Watergate conversations that promptly led him to be the first and only President in history to resign from office. ${ }^{33}$

Thus, a great deal of constitutional-law-in-action takes place between Congress and the executive branch. And those complex interactions sometimes end up before the Court for review. But it is worth noting that much of that activity is ultimately beyond the purview of the judiciary's responsibility to decide cases and controversies. ${ }^{34}$ The Supreme Court's fundamental understanding of its power of judicial review includes a recognition that there are some questions of constitutional law that are nonjusticiable political questions. ${ }^{35}$ In those areas of government decision making, such as most aspects of foreign policy, the coordinate elected branches presumably have the final word on how they should proceed — constitutionally speaking. Thus, all three branches have some legitimate claim on the authority to interpret the Constitution, although the Supreme Court insists on having the last word. ${ }^{36}$

31 See generally William E. Leuchtenburg, THE Supreme CoURT ReborN: The CONSTITUTIONAL REVOLUTION IN THE AGE OF RoOSEVELT (1995).

32 Youngstown Sheet \& Tube Co. v. Sawyer, 343 U.S. 579 (1952). See generally MAEVA Marcus, Truman and the SteEl Seizure Case: THE Limits of Presidential Power (rev. ed. 1994); Alan F. Westin, THE ANATOMy of A CONSTItUTIONAL CaSE (rev. ed. 1990).

33 Nixon v. United States, 418 U.S. 683 (1974). See BAKER \& WILLIAMS, supra note *, at $276-85$.

${ }^{34}$ See generally BAKER \& WILIIAMS, supra note *, at 62-73; THOMAS E. BAKER, Federal Court Practice and Procedure: A THIRd BranCh BIBl IOGRaPhy 39-51 (2001); ERWIN CHEMERINSKY, FEDERAL JURISDICTION 43-167 (4th ed. 2003); ChARLES ALAN WRIGHT \& MARY KAY KANE, LAW OF FEDERAL COURTS 27-101 (6th ed. 2002).

35 See, e.g., Goldwater v. Carter, 444 U.S. 996 (1979); Powell v. McCormack, 395 U.S. 486 (1969); Baker v. Carr, 369 U.S. 186 (1962). But see Bush v. Gore, 531 U.S. 98 (2000). See generally BAKER \& WILLIAMS, supra note *, at 88-90; Rachel E. Barkow, More Supreme Than Court?: The Fall of the Political Questions Doctrine and the Rise of Judicial Supremacy, 102 Colum. L. REV. 237 (2002); Mark Tushnet, Law and Prudence in the Law of Justiciability: The Transformation and Disappearance of the Political Question Doctrine, 80 N.C. L. REV. 1203 (2002).

36 The last-mentioned doctrine of nonjusticiability is an illustration of how the Court jealously guards the judicial prerogative:

There is, thus, a political question doctrine. It does not mark certain provisions of the Constitution as off-limits to judicial interpretation. But it does require federal courts to determine whether constitutional provisions which litigants would have judges enforce do in fact lend themselves to interpretation as guarantees of enforceable rights. To make such a determination, a court must first of all construe the relevant constitutional text, and seek to identify the purposes the particular provision serves within the constitutional scheme as a whole. At this 
The answer to the question "Who interprets the Constitution?" plays out in a considerably more straightforward manner along the axis of federalism. ${ }^{37}$ The dominance of the Supreme Court in matters of constitutional law was established early in the Republic. The Supreme Court of the United States saw to that. In a quick succession of textbook decisions for federal judicial supremacy over the states, acts of state legislatures were declared unconstitutional, ${ }^{38}$ state criminal proceedings were made subject to review, ${ }^{39}$ and final decisions of the highest courts of the states were deemed reviewable in the Supreme Court under the Constitution. ${ }^{40}$ The Civil War killed the political theory of John C. Calhoun that the states had the right to resist national supremacy. ${ }^{41}$ When modern "Confederates" tried to revive the idea of "states' rights" to keep from desegregating their public schools, the Supreme Court would hear none of it. A unanimous opinion, signed by all nine Justices, declared "the basic principle that the federal judiciary is supreme in the exposition of the law of the Constitution, and that principle has ever since been respected by this Court and the Country as a permanent and indispensable feature of our constitutional system."

Thus, the answer to the "Who" question is that all the governmental actors in the national and state governments are called upon routinely to interpret the Constitution

\begin{abstract}
stage of the analysis, the court would find particularly relevant the fact that the constitutional provision by its terms grants authority to another branch of government; if the provision recognizes such authority, the court will have to consider the possibility of conflicting conclusions, and the actual necessity for parallel judicial and political remedies. But ultimately, the political question inquiry turns as much on the court's conception of judicial competence as on the constitutional text. Thus the political question doctrine, like other justiciability doctrines, at bottom reflects the mix of constitutional interpretation and judicial discretion which is an inevitable by-product of the efforts of federal courts to define their own limitations.
\end{abstract}

1 TRIBE, supra note $2, \S 3-13$, at 385 (citations omitted).

${ }^{37}$ See generally BAKER \& WILLIAMS, supra note *, at 246-97; Lynn A. Baker \& Ernest A. Young, Federalism and the Double Standard of Judicial Review, 51 DUKEL.J. 75 (2001); Thomas E. Baker, A Catalogue of Judicial Federalism in the United States, 46 S.C. L. REV. 835 (1995); Edward L. Rubin \& Malcolm Feeley, Federalism: Some Notes on a National Neurosis, 41 UCLA L. REV. 903 (1994).

38 Fletcher v. Peck, 10 U.S. (6 Cranch) 87 (1810).

39 Cohens v. Virginia, 19 U.S. (6 Wheat.) 264 (1821).

40 Martin v. Hunter's Lessee, 14 U.S. (1 Wheat.) 303 (1816).

41 See generally JoHn Niven, JoHn C. CALHoun AND THE PRICE OF UNion: A BIOGRAPHY (1988); William Ty Mayton, "The Fate of Lesser Voices": Calhoun v. Wechsler on Federalism, 32 WAKE FOREST L. REV. 1083 (1997).

42 Cooper v. Aaron, 358 U.S. 1, 18 (1958). See generally BAKER \& WILLIAMS, supra note *, at 53-62; Larry D. Kramer, Foreword: We the Court, 115 HARV. L. REV. 4 (2001). 
in the performance of their governmental duties. ${ }^{43}$ But the Supreme Court usually has the last word, unless the Court itself concludes that the Constitution gives the last word to Congress or the President. The Court's papal-like authority was once aptly described by Justice Jackson: "We are not final because we are infallible, but we are infallible only because we are final."

It is the commonplace understanding, of course, that the Supreme Court has the ultimate responsibility for interpreting the Constitution. But it is not a digression to emphasize that the High Court's power is derived from the Constitution and its decisions must be reasoned interpretations. Alexander Hamilton explained in Federalist Paper No. 78 that the judiciary "has no influence over either the sword or the purse" and that the Supreme Court "may truly be said to have neither FORCE nor WILL but merely judgment." ${ }^{\text {"45 }}$ There is a certain family resemblance between what the Supreme Court of the United States does and what a state supreme court does. Both courts decidecases. Both courts provide reasoned opinions and justifications for theirdecisions.

But they are not the same kind of court. When a state supreme court decides a tort case to discard the rule of contributory negligence and adopt the rule of comparative negligence or decides a contract case by declaring that the parol evidence rule provides that a writing intended by the parties to be the final embodiment of their agreement may not be contradicted by other kinds of evidence, the state supreme court is doing something different. Besides deciding the case sub judice, the state judges are declaring the common law for the state. They are performing as policy-makers for the state. They are expected to reason towards what they themselves believe is the best public policy, the best rule of law, for the state. ${ }^{46}$

Strictly speaking, Justices on the Supreme Court of the United States do not have that kind of power or authority. They are interpreters of the Constitution. ${ }^{47}$ Their power of judicial review derives from the legitimacy and the supremacy of the Constitution and not from their personal and subjective policy preferences. They cannot strike down an otherwise valid statute merely because they do not personally approve of the public policy. They cannot impose a requirement on the legislative branch or the executive branch solely because they themselves think it is a really good idea. Otherwise, constitutional law would amount to the "rule of five" - at any given time whatever five Justices liked would be constitutional and whatever

${ }^{43}$ See U.S. ConST. art. VI, cls. $2 \& 3$.

${ }^{44}$ Brown v. Allen, 344 U.S. 443, 540 (1953) (Jackson, J., concurring).

${ }^{45}$ THE FEDERALIST No. 78, at 465 (Alexander Hamilton) (Clinton Rossiter ed., 1961).

${ }^{46}$ "State courts have available to them for decision a number of sources - state constitutions, statutes, and common law - which are not available to us." Cruzan v. Dir., Mo. Dep't of Health, 497 U.S. 261, 277 (1990).

${ }^{47}$ The authority of the Supreme Court to interpret the Constitution - which is the subject of this article - is something different and apart from the Court's authority to interpret federal statutes or to develop federal common law. See generally CHEMERINSKY, supra note 34 , at 353-89. 
five Justices did not like would be unconstitutional. That is not the theory or philosophy of American constitutionalism. ${ }^{48}$

What Karl Von Clausewitz is supposed to have said about war might be said about constitutional law: "it is a continuation of politics by other means." 49 Presidents nominate and the Senate confirms the members of the Supreme Court, but once on the Court, the Justices are not supposed to behave like the elected officials in the political branches behave. They are supposed to behave like judges. From the original decision establishing the major premise of judicial review, Marbury v. Madison, to the present day, the fundamental premise is that the law of the Constitution is something different from politics. It would be illegitimate for a Justice or a majority of the Justices to write an opinion that says, "The Constitution does not require or in any way justify our decision today in this case, but we think we have reached the right result and we are satisfied that this ruling is a good idea."

Anyone who can read can tell you what the Constitution says; but we need the Supreme Court to interpret what the Constitution ultimately means. To be sure, the answer is not always easy or obvious, even to the Justices themselves, as is demonstrated by the plethora of concurring and dissenting opinions in controversial cases as well as by the relative frequency of overrulings of prior precedents.

Like rock-and-roll, judicial review is here to stay, with all due respect to Justice Antonin Scalia, who declined to comment on Marbury v. Madison during his Senate confirmation hearing, because he said the issue might come before the Supreme Court. Really. ${ }^{50}$ However, a noteworthy development in the 1990s was the nuclear critique against the Supreme Court's power and performance. Robert H. Bork, the Reagan nominee who was not confirmed to the Supreme Court and one of the most conservative constitutionalists on the right, and Georgetown University's Mark Tushnet, one of the most liberal constitutionalists on the left, both published booklength manifestos against judicial review. Bork would allow the Supreme Court to continue to decide constitutional cases, but would amend the Constitution to authorize Congress to overrule an interpretation of the Constitution by a simple majority vote. ${ }^{51}$ Tushnet would go further to eliminate judicial review in the courts by a constitutional amendment, leaving the task of constitutional interpretation to

48 See generally BAKER \& WILLIAMS, supra note *, at 1-52.

49 The quotation is translated in a variety of forms. See Columbia WORLD OF QUOTATIONS no. 12605 (1996); Frank Michelman, Bringing the Law to Life: A Plea for Disenchantment, 74 CORNELL L. REV. 256 (1989).

so David Alistair Yalof, Pursum of Justices: Presidential Polttics and the SELECTION OF SUPREME COURT NOMINEES 154-55 (1999). See generally ANTONIN SCALIA, A MATTER OF INTERPRETATION: FEDERAL COURTS AND THE LAW (1997).

51 See ROBERT H. BORK, SLOUCHING TOWARDS GOMORRAH: MODERN LIBERALISM AND AMERICAN DECLINE 96-1 19 (1996); Thomas E. Baker, Bob Borks Amerika, 44 UCLA L. REV. 1185 (1997) (book review). 
Congress and populist politics. ${ }^{52}$ These two prominent heretics, and numerous other scholars and commentators who have joined in the intellectual fray, demonstrate how the dogma of judicial review still remains controversial. ${ }^{53}$

\section{WHAT IS THE CONSTITUTION?}

This is a serious question for constitutional theory: Just what is included in the Constitution for purposes of interpretation? What are the sources and references that properly can be brought to bear to resolve a question of constitutional law? The content of the canon for constitutional interpretation, i.e., what sources provide constitutional meaning, depends somewhat on the interpretative issue and varies somewhat from one interpreter to another. ${ }^{54}$ Several standard sources will be discussed here: text, original understanding, history and tradition, structure, precedent or doctrine, and philosophy or moral reasoning.

Do not lose sight of the background and context of constitutional argumentation in practice. Lawyers write briefs and make arguments to judges, who are lawyers too. Legal argumentation limits and constrains; legal conventions help define the way judges perform the task of judging. Judges are obliged to write reasoned opinions giving the justifications for their decisions, unlike members of Congress or the President. The opinions must be more than an expression of the Justices' personal predilections and policy-preferences. Decisions are expected to be sincere and consistent over time. Judicial candor is a prerequisite. The Supreme Court is a collegial court: only a majority can exercise the power of judicial review - it takes five votes. An individual Justice cannot do anything but fulminate without four more Justices in agreement. This is in the nature of the institution and inherent in its function. ${ }^{55}$

There has been a half-century long debate over how "principled" Supreme Court decision-making has been or can be. The debate has joined issue over whether there are "neutral principles" that distinguish law from politics, i.e., that a judge can and should look outside the judge's personal values for reasons for a decision that transcend the individual judge or the particular case. Judges should not be merely result-oriented to decide a case the way they want it to come out. This is the basis

52 Mark Tushnet, TAKIng THE CONSTitution AWAY From THE CourTs (1999). See Thomas E. Baker, Marbury v. Madison - Requiescat in Pace?, 83 JUdiCATURE 83 (1999) (book review).

${ }^{53}$ See, e.g., Jack Wade Nowlin, The Judicial Restraint Amendment: Populist Constitutional Reform in the Spirit of the Bill of Rights, 78 NOTRE DAME L. REV. 171 (2002); Judicial Review, supra note 12.

${ }^{54}$ See generally J.M. Balkin \& Sanford Levinson, The Canons of Constitutional Law, 111 HARV. L. REV. 963 (1998); Symposium, The Canon(s) of Constitutional Law, 17 ConsT. COMMENT. 187 (2000).

${ }^{55}$ See Frank H. Easterbrook, Ways of Criticizing the Court, 95 HARV. L. REV. 802 (1982). 
for evaluating the legitimacy of Supreme Court decisions - neutral principles derived from the Constitution. Critics doubt whether this is anything more than a judge confusing what seems sensible or natural to the individual judge with a mythical principle of natural law or whatever. They believe that all judging is result-oriented, and they think that is a good thing because it assures good results in individual cases and in the run of cases. They defy anyone to go down the table of contents in a constitutional law casebook and try to sort and separate "principled decisions" from "result-oriented decisions." Critics say every person who does this would come up with different lists and the lists would reveal more about the person than about the decisions. The debate over "neutral principles" has been raging ever since the 1950s when Herbert Wechsler ${ }^{56}$ of Columbia University published his hostile critique of the opinion in Brown v. Board of Education ${ }^{57}$ - a decision everyone today would agree that reached the "right result" - and the debate has been rejoined over numerous controversial decisions over the years - controversial and controverted decisions such as the abortion case, Roe $v$. Wade. ${ }^{58}$

More recently, the University of Chicago's Cass Sunstein sought to transform the case-by-case result-oriented approach from a vice into a preferred value in his writings about the Rehnquist Court, extolling what he called the model of "judicial minimalism." 59 The methodology of minimalism is to leave important questions unresolved, to go about deciding the particular case on the particular facts, to write opinions narrowly rather than broadly, and to write shallow opinions that are not so deep as to be over-theorized. According to this approach, an opinion is a good opinion if it is "sufficient unto the case." Under this view, it is a good thing for an opinion to be case-bound. ${ }^{61} \mathrm{~A}$ judicial opinion should not read like a law review

56 Herbert Wechsler, Toward Neutral Principles of Constitutional Law, 73 HARV. L. REV. 1 (1959).

57347 U.S. 483 (1954). See generally WHAT BROWN V. BOARD OF EDUCATION SHOULD HAVE SAID (Jack M. Balkin ed., 2001).

58410 U.S. 113 (1973). See generally LAURIE SHRAGE, ABORTION AND SocLaL RESPONSIBILITY: DEPOLARIZING THE DEBATE (2003); DAVID J. GARROW, LIBERTY AND SEXUALITY: The Right to PRIVACY AND the MAKING OF ROE V. WADE (1994); Michael Stokes Paulsen, The Worst Constitutional Decision of All Time, 78 NOTRE DAME L. REV. 995 (2003); Symposium on Twenty-Five Years of Roe v. Wade: The Legal Evolution of Reproductive Freedom and Prenatal Rights, 62 ALB. L. REV. 801 (1999).

59 Cass R. Sunstein, One Case at a Time: Judicial Minimalism on the Supreme COURT ix (1999).

60 Thomas E. Baker, Federal Reporter, Third Series: A Call for Opinions "Sufficient unto the Case," 5 SCRIBES J. LEGAL WRITING 142 (1994-95).

${ }^{61}$ But see Morrison v. Olson, 487 U.S. 654, 734 (1988) (Scalia, J., dissenting) ("The ad hoc approach to constitutional adjudication has real attraction, even apart from its worksaving potential. It is guaranteed to produce a result, in every case, that will make a majority of the Court happy with the law. The law is, by definition, precisely what the majority thinks, taking all things into account, it ought to be."). 
article. By this light, Chief Justice Warren's discursive opinion in Brown v. Board of Education was a good and true opinion: it declared de jure segregation in public school to be unconstitutional, announced the overruling of Plessy v. Ferguson, ${ }^{62}$ postponed the knotty issue of remedy for reargument, and left other kinds of public segregation for later decisions. ${ }^{63}$

\section{A. Text}

Nearly everyone believes that the text of the Constitution - the four corners of the document as amended ${ }^{64}$ - is the necessary beginning place of constitutional interpretation. ${ }^{65}$ An argument that the text need not be consulted or should be ignored ought to be looked upon with some suspicion. Different levels of commitment to the text trigger different names for these interpreters, which may carry subtly different connotations, including: "literalist," "textualist," "strict constructionist," "interpretivist," and "documentarian."

A clause-bound textualist focuses exclusively on a specific clause to interpret it on its own terms. The Court usually tries self-consciously to find the essential purpose behind the particular clause that is in play, like the Contract Clause, for example. ${ }^{67}$ Akhil Reed Amar, ${ }^{68}$ from Yale University, advocates the kind of "intratextualism" that Chief Justice Marshall used in his famous opinion in McCulloch $v$. Maryland, in which Marshall compared and contrasted similar language in different clauses to interpret the Necessary and Proper Clause within the structure of the Constitution. Using this technique, an interpreter pays close attention to syntax, organization, and significant similarities and important differences in the wording and phrasing of the Constitution.

Much of the text of the Constitution is government boilerplate, important boilerplate, but boilerplate nonetheless, and its obvious meaning is respected

62163 U.S. 537 (1896).

${ }^{63}$ See, e.g., Schiro v. Bynum, 375 U.S. 395 (1964) (per curiam); State Athletic Comm'n v. Dorsey, 359 U.S. 533 (1959) (per curiam); New Orleans City Park Improvement Ass'n v. Detiege, 358 U.S. 54 (1958) (per curiam); Holmes v. City of Atlanta, 350 U.S. 879 (1955) (per curiam); Mayor of Baltimore v. Dawson, 350 U.S. 877 (1955) (per curiam); Muir v. Louisville Park Theatrical Ass'n, 347 U.S. 971 (1954) (per curiam).

${ }^{64}$ See Thomas E. Baker, Towards A "More Perfect Union": Some Thoughts on Amending the Constitution, 10 WIDENER J. PUB. L. 1 (2000).

${ }_{65}$ See Steven G. Gey, A Constitutional Morphology: Text, Context, and Pretext in Constitutional Interpretation, 19 ARIz. ST. L.J. 587 (1987); Mark V. Tushnet, A Note on the Revival of Textualism in Constitutional Theory, 58 S. CAL. L. REv. 683 (1985).

${ }_{66}$ Not all scholars are enamored with the text of the Constitution. Indeed, sometimes they have contests to pick the stupidest clause. See, e.g., ConstITUTIONAL STUPIDITIES, Constitutional Tragedies (William N. Eskridge, Jr. \& Sanford Levinson eds., 1998).

${ }^{67}$ See, e.g., Home Bldg \& Loan Ass'n v. Blaisdell, 290 U.S. 398 (1934).

68 Akhil Reed Amar, Foreword: The Document and the Doctrine, 114 HARV. L. REV. 26 (2000); Akhil Reed Amar, Intratextualism, 112 HARV. L. REV. 747 (1999). 
without question. ${ }^{69}$ Representatives serve two-year terms $;{ }^{70}$ Senators serve six-year terms $;{ }^{71}$ we have regular congressional elections. Presidents do not try to run for a third four-year term, even if they wanted to run or even if enough of us wanted them to continue to serve. ${ }^{72}$ This settled experience leads to a common technique that tries to distinguish between specific-particularized clauses and general-broad clauses. The requirement that the President be thirty-five-years-old is specific. But a con law prof might try to obfuscate even such a seemingly specific clause. If the requirement was intended to assure "maturity and experience," then a person who is only thirty might qualify with the proper resume. ${ }^{73}$ If the requirement was intended back then to designate wise elders, then today a person should be about fifty according to adjustments in life span over the last two centuries. ${ }^{74}$ Does the requirement that the President be a "natural born citizen"75 exclude anyone delivered by a Caesarean section?" ${ }^{76}$ Does the use of the masculine pronoun "he" 77 in Article II mean that only males can serve as President? ${ }^{78}$ Does this kind of con law prof dialogue give you a Socratic headache? You can relax - unless one of them is your professor in the course - because none of them is ever going to get appointed to the Supreme Court in your lifetime. ${ }^{79}$

Then there are what Justice Jackson called the "majestic generalities" Constitution - generative clauses that invoke fundamental values like "Due Process" and "Equal Protection" and invite the interpreter to read into them content about

69 See Frederick Schauer, Easy Cases, 58 S. CAL. L. REv. 399 (1985); Robert A. Sedler, The Settled Nature of American Constitutional Law, 48 WAYNE L. REv. 173 (2002).

70 U.S. CONST. art. I, $\$ 2$.

${ }^{71}$ U.S. CONST. art. I, § 3, cl. 1.

72 U.S. CONST. amend. XXII.

73 See Richard A. Posner, Law and Literature: A Misunderstood Relation 219-20 (1988); Anthony D'Amato, Aspects of Deconstruction: The "Easy Case" of the Under-Aged President, 84 Nw. U. L. Rev. 250 (1990); Gary Peller, The Metaphysics of American Law, 73 CAL. L. REV. 1151, 1174 (1985); Tushnet, supra note 65, at 686-88.

${ }^{74}$ See Michael Stokes Paulsen, Is Bill Clinton Unconstitutional? The Case for President Strom Thurmond, 13 CoNST. COMMENT. 217 (1996). Senator Thurmond died since this article was written, however, and at least one interpretation of the Constitution would require that the President be a living person.

${ }^{75}$ U.S. CONST. art. II, \$ 1, cl. 4.

76 See Paul Brest, The Misconceived Quest for the Original Understanding, 60 B.U. L. REV. 204, 207 (1980).

77 U.S. ConST. art. II.

78 See Akhil Reed Amar, Our Forgotten Constitution: A Bicentennial Comment, 97 YALE L.J. 281, 292-93 (1987).

79 See Mark Tushnet, The Dilemmas of Liberal Constitutionalism, 42 OнІо ST. L.J. 411 (1981). There are some genuine issues of interpretation for the clause, however. See, e.g., James C. Ho, Unnatural Born Citizens and Acting Presidents, 17 CONST. COMMENT. 575 (2000); Christina S. Lohman, Presidential Eligibility: The Meaning of the Natural-Born Citizen Clause, 36 GONZ. L. REv. 349 (2000).

${ }^{80}$ W. Va. State Bd. of Educ. v. Barnette, 319 U.S. 624, 639 (1943). 
fairness and equality. ${ }^{81}$ How does a judge decide what is fair or equal? When does the interpreter give up on the text in the face of such implicit indeterminacy? What is the next move? The most fundamentalist textualists would opine that if the answer is not found in the text then the matter is left to the elected branches and ultimately to the people. This theory thus would significantly limit the role of courts and judges. ${ }^{82}$ Some noted constitutionalists insist that it is inevitable to read values into the Constitution, and when judges pretend they are not doing so, they are only fooling themselves, and worse, sometimes they do it without knowing they are doing it. ${ }^{83}$ But the choice to read the text narrowly, to exercise judicial self-restraint, is itself an interpretive choice that requires some justification. The Constitution does not say to the reader, "read me strictly" or "read me loosely," and presumably it would do similar harm to the text to read a narrow clause broadly as to read a broad clause narrowly. ${ }^{84}$ To interpret individual liberty too narrowly or too broadly would be as unfaithful to the text as to interpret government power too broadly or too narrowly. We should expect from our interpreters what Stanford University's Lawrence Lessig calls "fidelity" to the original document, which allows the interpreter to translate the text from its original 18th-century context into the context of today. ${ }^{85}$ The comparison to translating from one language to another is a helpful metaphor for the process of interpretation. The faithful translator tries to convey the full meaning of the document, what it says and what its author intended, seeking to avoid losing something in the translation.

\section{B. Originalism}

Most of the attention in constitutional theory has been focused on the arguments for and against the theory of originalism since the 1980s when Attorney General Edwin Meese called for a return to the jurisprudence of original intent and that became a standard for the Reagan Administration's Supreme Court appointments. ${ }^{86}$

${ }^{81}$ Sometimes you can just look up a word in a dictionary, if you know where to look. See Ellen P. Aprill, The Law of the Word: Dictionary Shopping in the Supreme Court, 30 ARIZ. ST. L.J. 275 (1998); Gary L. McDowell, The Politics of Meaning: Law Dictionaries and the Liberal Tradition of Interpretation, 44 AM. J. LEGAL HIST. 257 (2000); Caleb Nelson, Originalism and Interpretative Conventions, 70 U. CHI. L. REV. 519 (2003); Rickie Sonpal, Note, Old Dictionaries and New Textualists, 71 FoRDHAM L. REV. 2177 (2003); Samuel A. Thumma \& Jeffrey L. Kirchmeier, The Lexicon Has Become a Fortress: The United States Supreme Court's Use of Dictionaries, 47 BufF. L. Rev. 227 (1999).

82 SCALIA, supra note 50, at 37-47.

${ }^{83}$ See id. at 65-94 (discussing the views of Laurence H. Tribe),

${ }^{84}$ Richard A. Posner, What Am I? A Potted Plant?, New Repubuc, Sept. 28, 1987, at 24.

${ }^{85}$ Lawrence Lessig, Fidelity in Translation, 71 TEX. L. REv. 1165 (1993). Of course, the virtue of fidelity poses the further question "What is the Constitution?" James E. Fleming, Fidelity to Our Imperfect Constitution, 65 FoRDHAM L. REV. 1335, 1335 (1997).

${ }^{86}$ Edwin Meese III, The Supreme Court of the United States: Bulwark of a Limited Constitution, 27 S. TEX. L. REv. 455 (1986). 
There are several varieties of originalists. ${ }^{87}$ Some pore over historical materials to ascertain the "original intent," i.e., how the Framers themselves subjectively would have decided the very issue before the Court. Others take as their polestar a more objective "original understanding" of the Constitution, i.e., how the words of the Constitution would have been understood by a reasonable and informed interpreter at the time it was written. Originalism thus is an exercise in historiography. ${ }^{88} \mathrm{An}$ originalist looks backwards in time to recapture some purported meaning of the Constitution in the past. ${ }^{89}$

The allure of originalism is its appeal to the wisdom of the Framers, who have become something like political saints. ${ }^{90}$ Nonbelievers turn this around to reject the "dead hand of the past" - even worse, being ruled by dead white men - to delegitimize originalism as being profoundly antidemocratic. ${ }^{91}$ But the countermajoritarian difficulty has always been a shadow over judicial review whatever the interpretative methodology, and more importantly, if judicial review is justified by the will of the people expressed in the Constitution, then the judge must be dutybound to find and carry out that will. True believers insist that originalism is the one best method to keep judges from freelancing and imposing their own subjective policy preferences under the pretext of interpreting the Constitution. ${ }^{92}$

87 See generally EARL M. MALTZ, RETHINKING CONSTITUTIONAL LAW: ORIGINALISM, INTERVENTIONISM, AND THE POLITICS OF JUDICIAL REVIEW (1994); CHRISTOPHER WOLFE, HOW TO READ THE CONSTITUTION: ORIGINALISM, CONSTITUTIONAL INTERPRETATION, AND JUDICIAL POWER (1996); Randy E. Barnett, An Originalism for Nonoriginalists, 45 LOY. L. REV. 611 (1999); Aileen Kavanagh, Original Intention, Enacted Text, and Constitutional Interpretation, 47 AM. J. JURIS. 255 (2002); Richard S. Kay, "Originalist" Values and Constitutional Interpretation, 19 HARV. J.L. \& PUB. POL'Y 335 (1996); Vasan Kesavan \& Michael Stokes Paulsen, The Interpretative Force of the Constitution's Secret Drafting History, 91 GEO. L.J. 113 (2003); Jonathan R. Macey, Originalism as an "Ism," 19 HARv. J.L. \& PUB. POL'Y 301 (1996).

88 See David A.J. Richards, Interpretation and Historiography, 58 S. CAL. L. REV. 489 (1985). See generally ERNST BREISACH, HISTORIOGRAPHY: ANCIENT, MEDIEVAL, \& MODERN (2d ed. 1994); G. EDWARD WHITE, INTERVENTION AND DETACHMENT: ESSAYS IN LEGAL HISTORY AND JURISPRUDENCE (1994).

${ }^{89}$ Mark D. Greenberg \& Harry Litman, The Meaning of Original Meaning, 86 GEO. L.J. 569 (1998); Michael Sink, Comment, Restoring Our Ancient Constitutional Faith, 75 U. COLO. L. REV. 921 (2004).

90 See Bernard BAll yn, To Begin THE WORLD ANEW: THE GENIUS AND AMBIGUITIES OF THE AMERICAN FOUNDERS (2003); THE FOUNDERS' ALMANAC: A PRACTICAL GUIDE TO THE NOTABLE Events, GREATEST LEADERS, AND MOST ELOQUENT WORDS OF THE AMERICAN FOUNDING (Matthew Spaulding ed., 2002); THOMAS G. WEST, VINDICATING THE FoUNDERS: RACE, SEX, ClASS, AND JUSTICE IN THE ORIGINS OF AMERICA (1997).

91 "Tradition is the living faith of the dead, traditionalism is the dead faith of the living. And, I suppose I should add, it is traditionalism that gives tradition such a bad name." JaROSlaV PElikan, The Vindication of Tradition 65 (1984). See David A. Strauss, Common Law, Common Ground, and Jefferson's Principle, 112 YALE L.J. 1717 (2003).

92 See Jonathan G. O'Neill, Raoul Berger and the Restoration of Originalism, 96 Nw.U. 
Academic critics - and they include most but not all con law profs - look upon originalism as a form of the occult. Serious challenges to originalism question whether the historical materials and the techniques of history are adequate to the interpretative task: ${ }^{93}$ sometimes the Framers did not debate the issue; sometimes they could not agree; sometimes they seemed to try to slant the materials they left behind; sometimes the text itself seems to direct the interpreter to go beyond the document, for example, the Cruel and Unusual Punishment Clause in the Eighth Amendment or the Ninth Amendment reference to "other rights" not enumerated there. Then, just who qualifies as a Framer?" The delegates at the Constitutional Convention who drafted and proposed the document? The delegates at the state ratifying conventions who made it law? Federalist supporters and Antifederalist opponents? The first Congress? Early Supreme Courts? Finally, there is the intriguing question that has filled the pages of the law reviews: what was the original intent about original intent, i.e., how did the Framers expect courts to interpret the Constitution? ${ }^{95}$

A critical and problematic issue for originalism is to ascertain the proper level of abstraction or generalization. ${ }^{96}$ For example, the issue in Mclntyre v. Ohio Elections Commission ${ }^{97}$ was whether the First Amendment protected anonymous political leafleting. Two leading proponents of originalism on the Supreme Court, Justice Thomas and Justice Scalia - both purporting to practice originalism - each relying on the same historical record - came to opposite constitutional conclusions about the original understanding. One of the most difficult challenges for an originalist is to distinguish between continuities and disjunctions - between

L.REV.253(2001); AntoninScalia, Originalism:TheLesserEvil,57U.CIN.L.REV.849(1989).

${ }^{93}$ See JaCk N. Rakove, ORIginal Meanings: Politics and IdEas IN the Making of THE CONSTITUTION (1997); Paul Finkelman, The Constitution and the Intentions of the Framers: The Limits of Historical Analysis, 50 U. PITT. L. REV. 349 (1989); William G. Michael, When Originalism Fails, 25 WHITTER L. REV. 497 (2004); G. Edward White, The Arrival of History in Constitutional Scholarship, 88 VA. L. REV. 485 (2002).

94 See generally BERNARD BAILYN, THE IDEOLOGICAL ORIGINS OF THE AMERICAN REVOLUTION (1967); CAROL BERKIN, A BRILIANT SOLUTION: INVENTING THE AMERICAN CONSTITUTION (2002); FoRREST MCDONALD, Novus ORDo SECLORUM: THE INTELLECTUAL ORIGINS OF THE CONSTITUTION (1985); RATIFYING THE CONSTITUTION (Michael Allen Gillespie \& Michael Lienesch eds., 1989); GoRdon S. WOOD, THE CREATION OF THE AMERICAN REPUBLIC, 1776-1787 (1969).

95 See Robert N. Clinton, Original Understanding, Legal Realism, and the Interpretation of "This Constitution," 72 IowA L. REV. 1177 (1987); Charles A. Lofgren, The Original Understanding of Original Intent?, 5 CONST. COMMENT. 77 (1988); William J. Michael, The Original Understanding of Original Intent: A Textual Analysis, 26 OHIO N.U. L. REV. 201 (2000); H. Jefferson Powell, The Original Understanding of Original Intent, 98 HARV. L. REV. 885 (1985).

96 See generally RONALD DWORKIN, TAKING RIGHTS SERIOUSLY 134-36 (1977) (distinguishing between the Framers' general concepts that ought to be binding and the Framers' particular conceptions that ought not to be binding).

97514 U.S. 334 (1995). 
circumstances that are constant and circumstances that are variable - between the founding and the present time and then to factor them into the constitutional decision one way or the other, either to constitutionalize the issue of public policy or to leave it to the majoritarian legislative processes. ${ }^{98}$

One thing that sets an originalist's teeth on edge is the current debate among the Justices over whether comparative constitutional analysis is an appropriate and a legitimate aspect of American judicial review. ${ }^{99}$ In order to interpret the Constitution, even an originalist must find guidance in another time and place. The Framers were Enlightenment thinkers and neoclassicists; they thought of themselves as pragmatic statesmen who were practicing political science. ${ }^{100}$ They self-consciously and forthrightly borrowed ideas from the great political thinkers in history. They were conversant with Aristotle, Cicero, Montesquieu and Locke, to name a few examples from ancient and modern times and from Greece, Rome, France, and England. Yet Justice Scalia, one of the leading proponents of originalism on the High Court today, maintains the basic distinction between a drafter and an interpreter, between a writer and a reader of the text, to proclaim that "comparative analysis [is] inappropriate to the task of interpreting a constitution, though it was of course quite relevant to the task of writing one." ${ }^{101}$ Thus, the modern interpretative question is whether constitutional law is only an American export to other countries, or whether it should be imported into the United States as well. ${ }^{102}$ As American-

98 Professor Barnett has asked the question that is the contrapositive of the power of judicial review to invalidate an unconstitutional law: why should anyone obey a constitutionallyvalid law? Randy E. Barnett, Constitutional Legitimacy, 103 CoLUM. L. REV. 111 (2003).

99 See, e.g., Lawrence v. Texas, 539 U.S. 558 (2003) (Kennedy, J., for the Court and Scalia, J., dissenting); Grutter v. Bollinger, 539 U.S. 306 (2003) (Ginsburg and Breyer, J.J., concurring); Atkins v. Virginia, 536 U.S. 304, 321-28 (2002) (Rehnquist, C.J., dissenting); Knight v. Florida, 528 U.S. 990 \& 993 (1999) (Thomas, J., concurring and Breyer, J., dissenting); Printz v. United States, 521 U.S. 898, 921 n.11 (1997); Thompson v. Oklahoma, 487 U.S. 815, 830-32, 869 n.4 (1988) (Stevens, J., for the Court and Scalia, J., dissenting).

100 It has been frequently remarked that it seems to have been reserved to the people of this country, by their conduct and example, to decide the important question, whether societies of men are really capable of establishing good government from reflection and choice, or whether they are foreverdestined to depend for their political constitutionson accident and force.

ThE FEDERAlist No. 1, at 33 (Alexander Hamilton) (Clinton Rossiter ed., 1961).

101 Printz, 521 U.S. at 921 n.11.

102 See generally William J. Brennan, Jr., The Worldwide Influence of the United States Constitution as a Charter of Human Rights, 15 Nova L. REv. 1 (1991); Sujit Choudhry, Globalization in Search of Justification: Toward a Theory of Comparative Constitutional Interpretation, 74 IND. L.J. 819 (1999); Clair L'Heureux-Dubé, The Importance of Dialogue: Globalization and the International Impact of the Rehnquist Court, 34 TULSA L.J. 15 (1998); Heinz Klug, Model and Anti-Model: The United States Constitution and the "Rise of World Constitutionalism," 2000 WIS. L. REV. 597. See also Ran Hirschl, The Political Origins of the New Constitutionalism, 11 IND. J. GlobAL LEGAL STUD. 71 (2004). 
style judicial review is franchised all around the McWorld, and as other countries develop and elaborate their own constitutional jurisprudence, ${ }^{103}$ this question likely will present itself more and more frequently, and with greater and greater immediacy to our own Supreme Court. ${ }^{104}$

\section{History \& Tradition}

Related to the historical quest for the original understanding is the interpretive approach to rely on history and tradition to give meaning to the Constitution. This approach is developmental. For example, the Supreme Court has recognized that an issue of separation of powers between the President and Congress is informed by historical practices and past institutional behavior. Long-standing, systematic, and continuous practices by the executive branch, in which the Congress has knowingly acquiesced, demonstrate a constitutional interpretation by those coequal branches that the Supreme Court will accept as an interpretive gloss on the executive power vested in the President in Article II. ${ }^{105}$ The idea is that history matters in constitutional interpretation, not just the history of the founding of the United States, but rather the entire history of the Constitution. ${ }^{106}$

Broader societal traditions can shape the scope of individual rights, as well, although the difficulty is in ascertaining the appropriate level of generality. In Michael H. v. Gerald $D .{ }^{107}$ the issue was the constitutionality of a state law presumption of paternity in favor of a husband when a child is born while the husband and wife are married and living together. ${ }^{108}$ The true biological father of

103 See generally COURTS, LAW, AND POLITICS IN COMPARATIVE PERSPECTIVE (Herbert Jacob ed., 1996); EDWARD MCWHINNEY, SUPREME COURTS AND JUdICIAL LAW-MAKING: CONSTITUTIONAL TRIBUNALS AND CONSTITUTIONAL REVIEW (1985); WILliam E. Nelson, MARBURY V. MADISON: THE ORIGINS AND LEGACY OF JUdICIAL REVIEW 104-13 (2000); Garry Sturgess \& PhIIP Chubb, Judging the World: LaW and Politics in the WORLD's LEADING COURTS (1988).

104 See generally Mauro Cappelletti, The "Mighty Problem" of Judicial Review and the Contribution of Comparative Analysis, 53 S. CAL. L. REV. 409 (1980); David Fontana, Refined Comparativism in Constitutional Law, 49 UCLA L. REV. 539 (2001); Ran Hirschl, Looking Sideways, Looking Backwards, Looking Fonwards: Judicial Review vs. Democracy in Comparative Perspective, 34 U. RICH. L. REV. 415 (2000); Michel Rosenfeld, Constitutional.Migration and the Bounds of Comparative Analysis, 58 N.Y.U. ANN. SURV. AM. L. 67 (2001); Mark Tushnet, The Possibilities of Comparative Constitutional Law, 108 YALE L.J. 1225 (1999); Symposium, Constitutional Borrowing, 1 I-CON 177 (2003), at http://icon.oupjournals.org.

105 Dames \& Moore v. Regan, 453 U.S. 654 (1981).

106 Barry Friedman \& Scott B. Smith, The Sedimentary Constitution, 147 U. PA. L. REV. 1 (1998).

107491 U.S. 110 (1989).

108 See generally J. Richard Broughton, The Jurisprudence of Tradition and Justice 
the child was in court trying to establish his parental rights. For the majority, Justice Scalia argued that the specific history and tradition of how the law treated illegitimacy afforded the biological father no Due Process rights. ${ }^{109}$ In dissent, Justice Brennan argued that the general history and tradition of protecting the institution of the family, and society's evolving sense of family, pulled in the direction of recognizing a constitutional interest in the biological father. ${ }^{110}$ The two were interpreting the history and tradition of Due Process on different levels of generality and from different perspectives. They brokered the constitutional needs for stability and change in different ways. Justice Scalia's approach to finding rights in history and tradition deferred to the majoritarian status quo of settled values. Justice Brennan's approach was more aspirational and progressive. He was more willing to exercise the power of judicial review to "draw its meaning from the evolving standards of decency that mark the progress of a maturing society." $111 \mathrm{He}$ believed in a "living Constitution." 12 The same kind of debate over the interpretive meaning of history and tradition was the background for a recent landmark, overruling decision (and the overruled decision, for that matter) that declared it is unconstitutional for a state to make it a crime for two consenting adults of the same gender to engage in certain sexual intimacies in the privacy of their home. ${ }^{113}$ The selective use of tradition requires that the interpreter be self-conscious about how and why tradition is being used as a source of constitutional meaning. ${ }^{114}$

Scalia's Unwritten Constitution, 103 W.VA.L.REV.19(2000); AnneC.Dailey, Constitutional Privacy and the Just Family, 67 TUL. L. Rev. 955 (1993); Peggy Cooper Davis, Contested Images of Family Values: The Role of the State, 107 HARV. L. REV. 1348 (1994); Adam B. Wolf, Fundamentally Flawed: Tradition and Fundamental Rights, 57 U. MIAMI L. REV. 101 (2002).

${ }_{109} 491$ U.S. at $127-28$ n.6.

${ }^{110}$ Id. at 139-41 (Brennan, J., dissenting).

111 Trop v. Dulles, 356 U.S. 86, 101 (1958).

112 See generally Herman BELZ, A Living CONSTITUTION OR FUNDAMENTAL LAw? American Constitutionalism in Historical Perspective (1998); Michael Kammen, A MaChINE THAT WOULD Go OF ITSELF: THE AMERICAN CONSTITUTION IN AMERICAN CUlTuRE (1986); Hadley Arkes, On the Novelties of an Old Constitution: Settled Principles and Unsettling Surprises, 44 AM. J. JURIS. 15 (1999); Howard Gillman, Living Constitution, in 4 ENCYCLOPEDIA, supra note 8, at 1632; Michael W. McConnell, Tradition and Constitutionalism Before the Constitution, 1998 U. ILL.L.REV. 173; William H. Rehnquist, The Notion of a Living Constitution, 54 TEX. L. REv. 693 (1976); Laurence H. Tribe \& Michael C. Dorf, Levels of Generality in the Definition of Rights, 57 U. CHI. L. REV. 1057, 1101 (1990).

113 Lawrence v. Texas, 539 U.S. 558 (2003) (overruling Bowers v. Hardwick, 478 U.S. $186(1986))$.

114 Rebecca L. Brown, Tradition and Insight, 103 YaLE L.J. 177 (1993); A.C. Pritchard \& Todd J. Zywicki, Finding the Constitution: An Economic Analysis of Tradition's Role in Constitutional Interpretation, 77 N.C. L. REv. 409 (1999). 
What might be called the Yale school of constitutional history is presented in the writings of Bruce Ackerman ${ }^{115}$ and Akhil Reed Amar. ${ }^{116}$ Those two celebrated scholars have developed elaborate and sophisticated analyses theorizing that the people of the United States may act outside Article $V$ to effect enduring constitutional change. They believe that history trumps text. Ackerman distinguishes between "normal politics" and rare "constitutional moments'117 of higher politics when the government and the people are focused in a crisis over an important constitutional issue. He identifies the founding, Reconstruction, and the New Deal as three 'constitutional moments' in American history which signaled a revolutionary reform, a profound shift in constitutional understanding that was the equivalent of formal amendment. ${ }^{118}$ Amar maintains that the Framers empowered popular majorities to sit in judgment of government and, when necessary, to disassemble the Constitution and implement radical reforms of a fundamental nature without having to go through the super-majority procedures required to formally amend the Constitution. ${ }^{119}$ More traditional constitutionalists, such as Laurence Tribe, are taken aback by these theories. ${ }^{120}$ Popular sovereignty is formally provided and required in Article $\mathrm{V}$, and these extra-textual theories are lacking in the proper respect an interpreter owes the text. When the Framers set out the sole constitutional way to amend the Constitution, they were not required to explicitly negate all other political theories for accomplishing change. Thus, most constitutionalists, including me, believe that Article V means what it says. ${ }^{121}$

Finally, the practical reality is that judges and lawyers are trained in law, not history; they are trained to make legal arguments. Indeed, what passes for historical understanding in judicial opinions and briefs often is snickered at by real historians as "law office history" that is highly-selective and adversarial, more of a search for telling arguments than an academic exercise in understanding the past. Some historians would compare writing about the past to predicting the future, and they even insist that "postdicting" the past is more like writing a novel than nonhistorians can appreciate. But legal historian Neil Richards has made this telling

115 Bruce A. Ackerman, We the People: Foundations (1991).

116 AKHIL ReEd AMAR, THE BILL OF Rights: CreAtion AND ReCONSTRUCTION (1998).

117 ACKERMAN, supra note 115, at 230.

118 Id. at 40.

119 See AMAR, supra note 116, at 119-22.

${ }^{120}$ Laurence H. Tribe, Taking Text and Structure Seriously: Reflections on Free-Form Method in Constitutional Interpretation, 108 HARV. L. REv. 1221 (1995).

121 "These arguments, while sophisticated, are, in the end, unconvincing." 1 TRIBE, supra note 2, $§ 1-20$, at 106. "My own view of Article $V$ is that it means what it says, and it says all that it means." Thomas E. Baker, Exercising the Amendment Power to Disapprove of Supreme Court Decisions: A Proposal for a "Republican Veto," 22 HASTINGS ConST. L.Q. 325, 344 n.61 (1995). 
point: we should expect the Supreme Court to rely on history as it makes history, but we should not expect the Justices to make up history. ${ }^{122}$

\section{Structure}

The deep structure of the Constitution is vertically arrayed in federalism (the relation between the national government and the states) and horizontally arrayed in separation of powers (the elaborate system of checks and balances among the three branches of the national government). ${ }^{123}$

Charles Black, who taught at the law schools at Yale and Columbia, used structural reasoning about the Constitution based on federalism and national supremacy to defend the Warren Court from critics who attacked its decisions from a states' rights perspective. ${ }^{124}$ An early historic example was the federalism and Supremacy Clause reasoning Chief Justice Marshall used in McCulloch v. Maryland ${ }^{125}$ to forbid the state to tax the federally-chartered Bank of the United States out of business. One need not be a Federalist to understand that the structure of federalism could not allow it. More recently, in United States Term Limits, Inc. $v$. Thornton, ${ }^{126}$ there was quite a debate between Justice Stevens and Justice Thomas over the structure of federalism regarding the power of the state to impose term limits on its own members of Congress. For the majority, Justice Stevens said that the structure of the Constitution and the principles of democratic theory forbade an individual state from adding to the qualifications in the Constitution. ${ }^{127}$ In dissent, Justice Thomas interpreted the Tenth Amendment and the structure of federalism to permit it. ${ }^{128}$

122 Neil M. Richards, Clio and the Court: A Reassessment of the Supreme Court's Uses of History, 13 J.L. \& POL. 809 (1997). See also H. JEFFERSON POWEL, A COMMUNITY BuILT ON WORDS: THE CONSTITUTION IN HISTORY AND POLITICS (2002); Herman Belz, History, Theory, and the Constitution, 11 CONST. COMMENT. 45 (1994); Laura Kalman, Border Patrol: Reflections on the Turn to History in Legal Scholarship, 66 FORDHAM L. REV. 87 (1997); Alfred H. Kelly, Clio and the Court: An Illicit Love Affair, 1965 SUP. CT. REV. 119; Buckner F. Melton, Jr., Clio at the Bar: A Guide to Historical Method for Legists and Jurists, 83 MINN. L. REV. 377 (1998); Jack N. Rakove, Fidelity Through History (Or To It), 65 FORDHAM L. REV. 1587 (1997); William M. Wiecek, Clio as Hostage: The United States Supreme Court and the Uses of History, 24 CAL. W. L. REV. 227 (1988). Professor Harrison has succinctly summarized two competing views of history: "History may be just one damned thing after another. Or maybe it's the same damned thing over and over again." John Harrison, Words, Words, Words, All the Way Down?, 7 GREEN BAG 2D 91, 91 (2003).

123 See generally BAKER \& WILLIAMS, supra note *, at 246-97.

124 Charles BLACK, STRUCTURE AND RELATIONSHIP IN CONSTITUTIONAL LAW (1969).

12517 U.S. (4 Wheat.) 316 (1819).

126514 U.S. 779 (1995). See generally Robert G. Natelson, The Enumerated Powers of States, 3 NEV. L.J. 469 (2003).

127514 U.S. at 827.

${ }^{128}$ Id. at $847-48$ (Thomas, J. dissenting). 
Alexander Bickel, from Yale University, set out the elementary problem for structural reasoning in terms of the "countermajoritarian difficulty" presented by judicial review. ${ }^{129}$ How is it that an unelected and largely unaccountable Supreme Court should wield the power to set aside the considered judgments of the people's elected representatives in the legislature? He suggested that judicial review was a kind of "deviant" practice in a democracy. ${ }^{130}$ There are few restraints on judges beyond self-restraint, a reality that has the potential to make the interpreters of the Constitution more important than the Constitution itself. A bad side effect of this tendency towards judicial oligarchy is that the democratic and participatory instincts of the people and their representatives can atrophy after they become accustomed to turning over difficult and divisive issues to the courts. This is a troublesome turn of events in a system of government built upon the consent of the governed. Ever since Bickel wrote, back in the 1960s, generations of scholars have debated the legitimacy of judicial review in terms of the countermajoritarian difficulty. ${ }^{131}$

Other constitutionalists insist that the countermajoritarian difficulty is not so prevalent or problematic and that the Court gets out of whack with the other branches and the rest of the country only for brief, temporary periods and at irregular, even rare, intervals. ${ }^{132}$ They worry that the Justices are not countermajoritarian enough, that they reflect majoritarian values too much and too often. Indeed, Vanderbilt's Rebecca Brown blames Bickel for leading constitutionalists to wander in the desert for forty years. ${ }^{133}$ She insists that his initial move - to emphasize democracy and accountability - was wrong. ${ }^{134}$ She emphasizes instead that the overarching goal of the Constitution is to protect individual rights. ${ }^{135}$ In that structure, judicial review is a value, not a vice. ${ }^{136}$ The Constitution does not have a problem with judicial review; it has a problem with majoritarianism. The real, ongoing threat to individual liberty is government power. The greater the government power, the lesser the individual liberty; the greater the individual liberty, the lesser the government power. Government power and individual liberty are the two sides of a zero-sum relationship. Barry Friedman, at New York University, lately has done

129 AleXANDER BICKEL, THE LEAST DANGERous BRANCH: THE SuPREME COURT AT THE BAR OF POLITICS (1962).

130 Id. at 18.

131 See generally Kenneth Ward, The Counter-Majoritarian Difficulty and Legal Realist Perspectives of Law: The Place of Law in Contemporary Constitutional Theory, 18J.L.\&POL. 851 (2002).

${ }^{132}$ See generally Michael J. Klarman, Rethinking the Civil Rights and Civil Liberties Revolutions, 82 VA. L. REV. 1 (1996); Steven L. Winter, An Upside/Down View of the Countermajoritarian Difficulty, 69 TEX. L. REV. 1881 (1991).

133 Rebecca L. Brown, Accountability, Liberty, and the Constitution, 98 COLUM. L. REV. 531 (1998).

134 See id. at 531-36.

135 See id.

136 See id. 
a great deal of powerful thinking and writing on this subject, and insists that someone really concerned about the divide between law and politics would learn more about the Supreme Court, and would understand constitutional law better, by examining popular reactions to Supreme Court decisions than by the more common approach of examining how the Justices react to popular politics. ${ }^{137}$ Furthermore, he advocates getting beyond this academic fixation with theory in order to normatively sort good and bad exercises of judicial review in a sustained manner before we can go on to contemplate whether the entire enterprise of judicial review is worthwhile. ${ }^{138}$ Friedman insists that we really do not know enough about how judicial review works to know whether it is a good idea in the first place. ${ }^{139}$

Perhaps the leading current proponent of a kind of structural reasoning is John Hart Ely, who was on the faculty at Harvard, Stanford and the University of Miami. ${ }^{140}$ Writing in the late 1970s and early 1980s, Ely can be credited with being the intellectual godfather of the entire contemporary generation of interpretative scholars. He set himself up as the chief apologist for the Warren Court and put orth a "representation-reinforcing" theory of judicial review which justified judicial intervention to eliminate structural or procedural problems in the political system that frustrated majorities and kept underrepresented minorities from full participation. ${ }^{141}$ Ely and his mentor, Chief Justice Warren, singled out the decision in Reynolds $v$. Sims ${ }^{142}$ that required apportionment of state legislative districts by population to insure "one person - one vote" equality as a paradigmatic ruling. By contrast, Ely could not find much good to say about Roe $v$. Wade ${ }^{143}$ as a constitutional holding, although he deemed protecting a woman's choice to have an abortion to be the appropriate policy for the legislature. ${ }^{144}$ Of course, as does everyone else, Ely has his critics. His former colleague at Harvard, Laurence Tribe, insisted that Ely has still not managed to escape substantive constitutional law by championing political process because the priority Ely gives process really amounts to a substantive value

137 Barry Friedman, The History of the Countermajoritarian Difficulty, Part Four: Law's Politics, 148 U. PA. L. REV. 971,976 (2000).

138 Barry Friedman, The Birth of an Academic Obsession: The History of the Countermajoritarian Difficulty, Part Five, 112 YALE L.J. 153, 256-59 (2002).

139 Id.

140 JOHN HART ELY, DEMOCRACY AND DISTRUST: A THEORY OF JUDICLALREVIEW (1981); JOHN HART ELY, ON CONSTITUTIONAL GROUND (1996). See generally Steven G. Calabresi, Textualism and the Countermajoritarian Difficulty, 66 GEO. WASH. L. REV. 1373 (1998); Michael J. Perry, The Legitimacy of Particular Conceptions of Constitutional Interpretation, 77 VA. L. REV. 669 (1991).

141 John Hart Ely, Toward a Representation-Reinforcing Mode of Judicial Review, 37 MD.

L. REV. 451 (1978).

142377 U.S. 533 (1964).

143410 U.S. 113 (1973).

144 John Hart Ely, The Wages of Crying Wolf: A Comment on Roe v. Wade, 82 YaLE L.J. 920 (1973). 
that posits, in effect, that more process and wider participation are always preferable and beneficial to the polity. ${ }^{145}$ Tribe maintains that value-free interpretation of the Constitution is neither possible nor in any way preferable. ${ }^{146}$ For example, the right to vote and who gets it and how it is exercised and regulated are all substantive questions. For Tribe, the whole enterprise of constitutional interpretation is about making choices to preserve important values. Under his view, that is not a detraction of constitutional law, it is its essential function and its greatest value. ${ }^{147}$

\section{E. Precedent or Doctrine $e^{148}$}

145 Laurence H. Tribe, The Puzzling Persistence of Process-Based Constitutional Theories, 89 YALE L.J. 1063 (1980). But see Michael J. Klarman, The Puzzling Resistance to Political Process Theory, 77 VA. L. REv. 747 (1991).

146 See Tribe, supra note 145.

147 Id.

148 Stare decisis et quieta non movere: "those things which have been so often adjudged ought to rest in peace," Spicer v. Spicer, 79 Eng. Rep. 451 (K.B. 1620). One could go on and on about precedent in the Supreme Court on matters of constitutional law ... . See generally Michael Abramowicz, Constitutional Circularity, 49 UCLA L. REV. 1 (2001); Christopher P. Banks, Reversals of Precedent and Judicial Policy-Making: How Judicial Conceptions of Stare Decisis in the U.S. Supreme Court Influence Social Change, 32 AKRON L. REV. 233 (1999); Christopher P. Banks, The Supreme Court and Precedent: An Analysis of Natural Courts and Reversal Trends, 75 JUDICATURE 262 (1992); C. Steven Bradford, Following Dead Precedent: The Supreme Court's Ill-Advised Rejection of Anticipatory Overruling, 59 FORDHAM L. REV. 39 (1990); Lea Brilmayer, The Conflict Between Text and Precedent in Constitutional Adjudication, 73 CORNELL L. REV. 418 (1988); William S. Consovoy, The Rehnquist Court and the End of Constitutional Stare Decisis: Casey, Dickerson and the Consequences of Pragmatic Adjudication, 2002 UTAH L. REV. 53; Charles J. Cooper, Stare Decisis: Precedent and Principle in Constitutional Adjudication, 73 CORNELL L. REV. 401 (1988); William O. Douglas, Stare Decisis, 49 ColuM. L. REv. 735 (1949); Frank H. Easterbrook, Stability and Reliability in Judicial Decisions, 73 CORNELLL. REV.422 (1988); Richard H. Fallon, Jr., Stare Decisis and the Constitution: An Essay on Constitutional Methodology, 76 N. Y.U.L. REv. 570 (2001); Philip P. Frickey, A Further Comment on Stare Decisis and the Overruling of National League of Cities, 2 CONST. COMMENT. 341 (1985); Philip P. Frickey, Stare Decisis in Constitutional Cases: Reconsidering National League of Cities, 2 Const. Comment. 123 (1985); Michael J. Gerhardt, The Role of Precedent in Constitutional Decision-making and Theory, 60 GEO. WASH. L. REV. 68 (1991); John Harrison, The Power of Congress over the Rules of Precedent, 50 DUKE L.J. 503 (2000); Patrick Higginbotham, Text and Precedent in Constitutional Adjudication, 73 CoRNELL L. REV. 411 (1988); Jerold H. Israel, Gideon v. Wainwright: The "Art" of Overruling, 1963 Sup. CT. Rev. 211; Andrew M. Jacobs, God Save This Postmodern Court: The Death of Necessity and the Transformation of the Supreme Court's Overruling Rhetoric, $63 \mathrm{U}$. CIN. L. REV. 1119 (1995); Harry W. Jones, Precedent and Policy in Constitutional Law, 4 PACE L. REV. 11 (1983); Maurice Kelman, The Forked Path of Dissent, 1985 SUP. CT. REV. 227; R. Randall Kelso \& Charles D. Kelso, How the Supreme Court Is Dealing with Precedents in Constitutional Cases, 62 BROOK. L. REV. 973 (1996); Margaret N. Kniffin, Overruling Supreme Court Precedents: Anticipatory Action by United States Courts of Appeals, 51 
The Constitution is something different and apart from constitutional law. This is illustrated in a backwards way by the perhaps apocryphal story that is told about a leading con law prof at Harvard at the beginning of the twentieth century, Thomas Reed Powell, who supposedly was fond of telling his students to refrain from read-

FoRdHAM L. Rev. 53 (1982); Anthony T. Kronman, Precedent and Tradition, 99 YALE L.J. 1029 (1990); Gary Lawson, The Constitutional Case Against Precedent, 17 HARv. J.L. \& PUB. POL'Y 23 (1994); Emery G. Lee III, Overruling Rhetoric: The Court's New Approach to Stare Decisis in Constitutional Cases, 33 U. ToL. L. Rev. 581 (2002); Thomas R. Lee, Stare Decisis in Economic Perspective: An Economic Analysis of the Supreme Court's Doctrine of Precedent, 78 N.C. L. REv. 643 (2000); Thomas R. Lee, Stare Decisis in Historical Perspective: From the Founding Era to the Rehnquist Court, 52 VAND. L. REV. 647 (1999); Younsik Lim, An Empirical Analysis of Supreme Court Decision Making, $29 \mathrm{~J}$. LEG.STUDIES 271 (2000); Earl Maltz, The Nature of Precedent, 66 N.C. L. REV. 367 (1988); Earl M. Maltz, Some Thoughts on the Death of Stare Decisis in Constitutional Law, 1980 Wis.L. REV. 467; Henry Paul Monaghan, Stare Decisis and Constitutional Adjudication, 88 COLUM. L. REV. 723 (1988); Henry P. Monaghan, Taking Supreme Court Opinions Seriously, 39 MD. L. REv. 1 (1979); Caleb Nelson, Stare Decisis and Demonstrably Erroneous Precedents, 87 VA. L. Rev. 1 (2001); Burt Neuborne, The Binding Quality of Supreme Court Precedent, 61 TUL. L. REv. 991 (1987); Erin O'Hara, Social Constraint or Implicit Collusion?: Toward a Game Theoretic Analysis of Stare Decisis, 24 SETON HALL L. REV. 736 (1993); Michael Stokes Paulsen, Abrogating Stare Decisis by Statute: May Congress Remove the Precedential Effect of Roe and Casey?, 109 YALE L.J. 1535 (2000); Christopher J. Peters, Foolish Consistency: On Equality, Integrity, and Justice in Stare Decisis, 105 Y ALE. L.J. 2031 (1996); Roscoe Pound, The Theory of Judicial Decision, 36 HARv. L. Rev. 940 (1923); Lewis F. Powell, Jr., Stare Decisis and Judicial Restraint, 47 WASH. \& LEE L. REv. 281 (1990); Antonin Scalia, The Rule of Law as a Law of Rules, 56 U. CHI. L. Rev. 1175 (1989); Frederick Schauer, Precedent and the Necessary Externality of Constitutional Norms, 17 HARV. J. L. \& PUB. POL'Y 45 (1994); Frederick Schauer, Precedent, 39 StAN. L. Rev. 571 (1987); Jeffrey A. Segal \& Robert M. Howard, How Supreme Court Justices Respond to Litigant Requests to Overturn Precedent, 85 JUDICATURE 148 (2001); David C. Bratz, Comment, Stare Decisis in Lower Courts: Predicting the Demise of Supreme Court Precedent, 60 WASH. L. REv. 87 (1984); Igor Kirman, Note, Standing Apart To Be a Part: The Precedential Value of Supreme Court Concurring Opinions, 95 COLuM. L. REv. 2083 (1995); David K. Koehler, Comment, Justice Souter's "Keep-What-You-Want-and-Throw-Away-the-Rest" Interpretation of Stare Decisis, 42 BUFF. L. REv. 859 (1994); Todd E. Freed, Comment, Is Stare Decisis Still the Lighthouse Beacon of Supreme Court Jurisprudence?: A Critical Analysis, 57 OHIO ST. L.J. 1767 (1996); Thomas J. Long, Note, Deciding Whether Conflicts with Supreme Court Precedent Warrant Certiorari, 59 N.Y.U. L. REv. 1104 (1984); Amy L. Padden, Note, Overruling Decisions in the Supreme Court: The Role of a Decision's Vote, Age, and Subject Matter in the Application of Stare Decisis After Payne v. Tennessee, 82 GEO. L.J. 1689 (1994); James C. Rehnquist, Note, The Power That Shall Be Vested in a Precedent: Stare Decisis, the Constitution and the Supreme Court, 66 B.U. L. REv. 345 (1986); John Wallace, Comment, Stare Decisis and the Rehnquist Court: The Collision of Activism, Passivism, and Politics in Casey, 42 BufF. L. REv. 187 (1994); Note, Constitutional Stare Decisis, 103 HARv. L. REV. 1344 (1990). 
ing the Constitution because "to do so would be apt to "confuse their minds." "149 Most teachers and students of constitutional law spend most of their time together analyzing Supreme Court opinions and talking about Court precedents or doctrines, i.e., past interpretations of the Constitution that seem to promise coherent and consistent answers in later cases. The typical law student does not need to be reminded that there is plenty of constitutional law that must be learned and mastered for the final examination and for the bar exam. Indeed, there are so many complex rules and elaborate doctrines that there is a lucrative market for student aids like Nutshells. Look around your student bookstore and you will see umpteen commercial outlines for every course and every casebook, each one promising to remove the scales from your eyes so that you may understand and be saved. The Supreme Court opinions we study are chock-full of balancing analyses, multi-factor tests, levels of scrutiny, tiers of analysis, et cetera, that provide a rule for decisions to be inserted in the famous "I-R-A-C" law school mantra of Issue-Rule-Analysis-Conclusion.

Constitutional doctrines articulate the relationship between the citizen and the government; constitutional doctrines define the boundary between individual liberty and government power. ${ }^{150}$ Doctrines promise some measure of consistency and objectivity in Supreme Court decision making. Doctrines promise to reduce the subjectivity and discretion of lower court judges. Whether or not doctrines actually deliver on those promises is another question.

Stare decisis in constitutional law is hierarchical in that all the rest of the courts in the country - federal and state - are obliged to follow controlling Supreme Court pronouncements on the Constitution of the United States. This has been a central tenet of American Constitutionalism from the founding to the present day. It is a critical feature of judicial review. ${ }^{151}$ The Supreme Court is the umpire of the separation of powers game among the branches of the national government. The Supreme Court is the cop on the federalism beat enforcing the Supremacy Clause. Stare decisis thus is also a critical feature of the constitutional structure. ${ }^{152}$ This is why we have "one supreme Court" - to quote the Constitution - there is only one and it is supreme. ${ }^{153}$ This is the strong force of precedent in constitutional law. ${ }^{154}$

Stare decisis in constitutional law also has the relatively weaker force of precedent from prior decisions felt over time by the Justices themselves, the members

149 Edward S. CoRwin, Constitutional ReVolution,LTd. 13 (Greenwood Press 1977) (1941) (quoting Professor Powell).

150 See generally BAKER \& WILLIAMS, supra note *, at 137-44.

151 See generally BAKER \& WILLIAMS, supra note *, at 53-91.

152 See generally id. at 246-97.

153 U.S. ConsT. art. III, § 1. See generally Thomas E. Baker, Why We Call the Supreme Court "Supreme," 4 GREEN BAG 2d 129 (2001).

154 See generally Steven P. Croley, The Majoritarian Difficulty: Elective Judiciaries and the Rule of Law, 62 U. CHI. L. REV. 689 (1995); Seth F. Kreimer, Exploring the Dark Matter of Judicial Review: A Constitutional Census of the 1990s, 5 WM. \& MARY BILL RTS. J. 427 (1997). 
of a constitutional court of last resort. ${ }^{155}$ In this regard, be reminded of your basic understanding of how any particular appellate court uses its past precedents to decide a present case. ${ }^{156}$ The deciding court, when faced with an issue and the task of applying one of its past precedents in the present case, has the power and the responsibility first to determine what the earlier precedent means, and second to determine whether it is controlling in the present case. What the individual members of the past court subjectively meant at the time it was decided or even how they might have decided the issue in the present case is not controlling. ${ }^{157}$

Some constitutional scholars are outright disdainful of precedent because they believe it to be so manipulable as to be pretextual and of doubtful legitimacy. ${ }^{158}$ Others hold up stare decisis as not merely one legitimate mode of constitutional argument, but the preferred mode of analysis for judges and academics. ${ }^{159}$ Liberals and conservatives alike do seem ready, able, and willing to emphasize "good" precedents and de-emphasize "bad" precedents for their own cause, however.

David Strauss of the University of Chicago maintains that constitutional law is nothing more or less than the accumulation of rules over time handed down by the Supreme Court in a process that very much resembles the judicial process of the common law. ${ }^{160} \mathrm{He}$ argues, like Professor Powell's tongue-in-cheek comment to his

155 The hierarchical quality of precedent is different from the horizontal quality in theory and in practice. See Rafael Gely, Of Sinking and Escalating: A (Somewhat) New Look at Stare Decisis, 60 U. PITT. L. REV. 89, 94 (1998).

156 EDWARD H. LEVI, AN INTRODUCTION TO LEGAL REASONING 1-27 (1949).

157 Id. at 1-8.

158 See, e.g., Coleman v. Alabama, 399 U.S. 1, $21-23$ (1970) (Burger, C.J., dissenting).

With deference, then, I am bound to reject categorically $\mathrm{Mr}$. Justice Harlan's and Mr. Justice White's thesis that what the Court said lately controls over the Constitution. While our holdings are entitled to deference, I will not join in employing recent cases rather than the Constitution, to bootstrap ourselves into a result .... By placing a premium on "recent cases" rather than the language of the Constitution, the Court makes it dangerously simple for future Courts, using the technique of interpretation, to operate as a "continuing Constitutional convention."

Id. at 22-23 (Burger, C.J., dissenting).

159 See, e.g., id. at 19 (Harlan, J., concurring in part and dissenting in part).

If I felt free to consider this case upon a clean slate I would have voted to affirm these convictions. But - in light of the lengths to which the right to appointed counsel has been carried in recent decisions of this Court - I consider that course is not open to me with due regard for the way in which the adjudicatory process of this Court, as I conceive it, should work.

Id. (Harlan, J., concurring in part and dissenting in part).

160 David A. Strauss, Common Law Constitutional Interpretation, 63 U. CHI. L. REV. 877 (1996). 
students mentioned above, that the text of the Constitution is insignificant compared to the content of Supreme Court opinions in the pages of U.S. Reports. ${ }^{161}$ That is how the principal actors in the system actually behave: Justices, lower court judges, attorneys, professors, and even students of constitutional law. He would give up on searching for the original understanding, et cetera. While this description admittedly does fit many of the behaviors of the principal actors, the theoretical implications would be profoundly unsettling: the Supreme Court would sit as an ongoing Constitutional Convention - final, infallible, and absolute. That would prove the undoing of many of the fundamental principles of American Constitutionalism: the republican form of government, the idea of limited and enumerated federal powers, the rule of law, in favor of something that amounted to a judicial oligarchy. ${ }^{162}$ For someone to say that constitutional law resembles the common law is one thing, but to say that the Supreme Court's interpretations are superior to the Constitution simply proves too much. ${ }^{163}$ At the same time, one supposedly could turn this argument around and insist that it is unconstitutional for the Supreme Court to adhere to its own precedents because the Constitution itself designates the Constitution - not federal common law — as the "supreme Law of the Land."164 University of Chicago professor Richard Epstein makes a different analogy to compare constitutional law with the civil law system, in which the statute or code is ascendant and the role of the court is merely adjudicative and adjunctive. ${ }^{155}$ First, the Court gives common meanings to words or clauses in the text to decide paradigm cases. Second, the Court extends those paradigms to cover new cases in a consistent and similar fashion. Third, the Court seeks to reconcile inconsistencies between competing paradigms. This allows for a creative and evolving judicial process for annotating the Constitution.

Following prior precedent promotes the even-handed, predictable, and consistent development of legal principles, and this applies as well to constitutional interpretation. It is an advantage not to have everything al ways "up for grabs." Constitutional law is different from other areas of the law. Justice Brandeis once explained how the Court must be even more willing to overrule its constitutional decisions than its interpretations of federal statutes because of the different risks of error

\footnotetext{
161 Id.

162 See generally BAKER \& WILLIAMS, supra note *, at 1-52.

163 See generally id. at 53-62.

164 U.S. CONST. art. VI, cl. 2. See also Michael Stokes Paulsen, Captain James T. Kirk and the Enterprise of Constitutional Interpretation: Some Modest Proposals from the TwentyThird Century, 59 AL. L. REv. 671,679 (1995); Note, Constitutional Stare Decisis, 103 HARV. L. REV. 1344, 1345 (1990).

165 Richard A. Epstein, A Common Lawyer Looks at Constitutional Interpretation, 72 B.U. L. REV. 699 (1992). See also George P. Fletcher, Three Nearly Sacred Books in Western Law, 54 ARK. L. REV. 1 (2001).
} 
under the separation of powers. ${ }^{166}$ If the Court gets a statute wrong, Congress can make a correction by ordinary legislation. If the Court gets the Constitution wrong, however, correction can be had only by the difficult and rare process of amending the Constitution. ${ }^{167}$ That has actually happened only four times in history and only once in the last one hundred years. ${ }^{168}$ The Supreme Court certainly does seem willing, even sometimes eager, to overrule its prior decisions. Indeed, the Rehnquist Court and its predecessor, the Burger Court, rank first and second respectively in overrulings on the all-time list. ${ }^{169}$ But not having the power to overrule a prior judicial interpretation of the Constitution would simply be intolerable given the major premise of judicial review in American constitutionalism. ${ }^{170}$

Thus, stare decisis is not an inexorable command in constitutional law for the Supreme Court. Generally, the determination to overrule a prior ruling takes into consideration whether the ruling has proved intolerable and unworkable in practice; whether the ruling has been the subject of the kind of societal reliance such that an overruling would result in special hardships; whether related principles of law have developed so that the ruling has become a mere remnant of abandoned doctrine; and whether facts have changed, or have come to be seen so differently, that the ruling has lost its justification and significance. In a self-conscious, jointly-authored plurality opinion, Justices O'Connor, Kennedy, and Souter reviewed the previous twenty years of judicial infighting and public debate over the right to an abortion to reaffirm the essential holding that had declared the right in the first place. Remarkably, they did so despite their admission that they would not have likely joined the majority in the original decision. ${ }^{171}$

That an individual Justice's attitude toward constitutional stare decisis greatly depends on the Justice's interpretative methodology is demonstrated by Justice Brennan's practice, followed by Justices Marshall and Blackmun, to dissent in every affirmance of a death penalty because he believed capital punishment was, in all

${ }^{166}$ Burnet v. Coronado Oil \& Gas Co., 285 U.S. 393, 406-10 (1932) (Brandeis, J., dissenting).

167 Id. See generally RICHARD B. BERNSTEIN \& FEROME AGEL, AMENDING AMERICAN: IF We Love the Constitution So Much, Why Do We KeEP TRYING To ChANGE IT? (1993); RESPONDING to IMPERFECTION: THE THEORY AND PRACTICE OF CONSTITUTIONAL AMENDMENT (Sanford Levinson ed., 1995).

${ }^{168}$ Baker, supra note 121 , at 342 n.53.

169 DAVID M. O'Brien, STORM Center: The Supreme Court in AMERICAN Politics 30 (6th ed. 2003).

${ }^{170}$ E.g., Brown v. Bd. of Educ., 347 U.S. 483 (1954) (overruling Plessy v. Ferguson, 163 U.S. $537(1896))$.

171 Planned Parenthood v. Casey, 505 U.S. 833 (1992). See also Agostini v. Felton, 521 U.S. 203, 234-38 (1997); Adarand Constructors, Inc. v. Pena, 515 U.S. 200, 229-37 (1995); Payne v. Tennessee, 501 U.S. 808, 827-30 (1991). 
circumstances, a violation of the Eighth and Fourteenth Amendments. ${ }^{172}$ As applied to a particular issue, the doctrine of stare decisis can be in conflict with any of the other methods of interpretation, of course. And it would be no doctrine at all if judges prepared to overrule a precedent were not obliged to give reasons. Often enough, the issue of constitutional law plays itself out in the debate over the meaning and significance of prior precedents. For example, by a vote of six to three and in a rather dramatic fashion, the Justices overruled a seventeen-year-old precedent and held that it was unconstitutional for a state to make it a crime for two consenting adults of the same gender to engage in certain sexual intimacies in the privacy of their home. ${ }^{173}$ Geoffrey Stone of the University of Chicago borrows a page from John Stuart Mill to urge all constitutional interpreters to exercise some humility about their own conclusions, given the inevitable fact that other interpreters, following other interpretive methodologies, have in the past and will in the future reach very different constitutional conclusions. ${ }^{174}$

Supreme Court opinions sometimes do not meet the expectations of students of constitutional law and often frustrate even veteran Court-watchers. But this is the nature of the judicial opinion on a collegial court. ${ }^{175}$ It is something quite different from a law review article. (I would not be the first one to wonder if part of the problem is that some of the current Justices who have an academic background still behave too much like law professors.) Try to imagine how a law review article would read if it were one of eighty full-length articles written by a committee of nine tenured senior professors, at least five of whom had to agree on every word and reference, all written simultaneously over the course of nine months. Furthermore, consider how much more is at stake in an opinion for the litigants and the country - the great weight of responsibility — is difficult to imagine. An opinion has different audiences, as well. The Court not infrequently engages in a dialogue with one or the other coordinate branches or with policy makers at the state level. ${ }^{176}$ Occasionally, the Court speaks to scholars, historians, and interested others.

172 E.g., McCleskey v. Kemp, 481 U.S. 279, 320 (1987). See generally William J. Brennan, Jr., In Defense of Dissents, 37 HASTINGS L.J. 427 (1986); Rory K. Little, Reading Justice Brennan: Is There a "Right" to Dissent?, 50 HASTINGS L.J. 683 (1999).

173 Lawrence v. Texas, 539 U.S. 558 (2003).

${ }_{174}$ Geoffrey R. Stone, Precedent, the Amendment Process, and Evolution in Constitutional Doctrine, 11 HARV. J.L. \& PUB. POL'Y 67 (1988). "[I]t could be said that Justice Scalia is sometimes wrong (or often wrong, depending on one's point of view) but never in doubt, while Justice Breyer is sometimes (or often) right, but usually, and quite publicly, in doubt." Linda Greenhouse, Between Certainty \& Doubt: States of Mind on the Supreme Court Today, 6 GREEN BAG 2d 241 (2003).

175 See generally Thomas E. Baker, The Intelligible Constitution, 10 CONST. COMMENT. 167 (1993) (reviewing JOSEPH GOLDSTEIN, THE INTELLIGIBLE CONSTITUTION (1992)).

176 See generally LOUIS FisheR, CONSTITUTIONAL DIALOGUES: INTERPRETATION AS Polttical Process (1988); KeIth E. WhitTington, Constitutional Construction: DIVIDED POWERS AND CONSTITUTIONAL MEANING (1999). 
But there are always three primary audiences: the parties before the Court, other judges including later Justices, and the citizenry. The Supreme Court has been likened to a "republican schoolmaster" tasked with providing the country with a high political education. ${ }^{177}$ Bryan A. Garner, the author of a leading book on legal writing, ${ }^{178}$ has criticized the writing style of Supreme Court opinions for, among other things, their verbosity, density, and opaqueness, which he mostly blames on law clerk ghostwriters. ${ }^{179}$ He singles out a few exceptional stylists: Chief Justice Marshall, and Justices Holmes and Jackson. For the ability to turn a phrase, honorable mentions go to: Justices Black, Brandeis, Cardozo, Douglas, Frankfurter, Scalia, and Chief Justice Rehnquist. Develop some appreciation for the different styles of writing and judging you observe in the pages of your casebook. Pay attention if your professor revealingly singles out a particular opinion or an individual Justice for this kind of high praise in class - it provides an insight about your own con law prof. Still, the task at hand for judges on any appellate court is to decide the case - to keep hold of a majority and to write an opinion with dispatch. ${ }^{180}$

\section{F. Philosophy or Moral Reasoning}

At the founding, political philosophy and moral reasoning took the form of natural rights and the laws of nature. ${ }^{181}$ These ideas explained the way Americans of that time thought about government, and are ideas Thomas Jefferson explained in the Declaration of Independence. ${ }^{182}$ Natural law in the Christian tradition consists of commands and prohibitions derived from divine revelation, such as the Ten Commandments, as is illustrated in the writings of Thomas Aquinas. ${ }^{183}$ But the

177 Ralph Lerner, The Supreme Court as Republican Schoolmaster, 1967 SUP. CT. REv. 127.

178 Bryan A. Garner, A Dictionary of Modern Legal Usage (2d ed. 1995).

179 Bryan A. Garner, Opinions, Style of, in THE OXFORd COMPANION TO THE SUPREME Court of THE UNITED STATES 607-11 (Kermit L. Hall et al. eds., 1992). See also Richard A. POSNER, LAW AND LITERATURE: A Misunderstood RELATION 269-316 (1988); Ray Forrester, Supreme Court Opinions - Style and Substance: An Appeal for Reform, 47 HASTINGS L.J. 167 (1995).

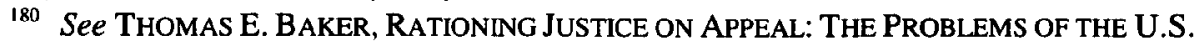
COURTS OF APPEALS 21-27, 119-21 (1994).

181 See generally BAILYN, supra note 94; Thomas E. Baker \& James E. Viator, NotAnother Constitutional Law Course: A Proposal to Teach a Course on the Constitution, 76 IOWA L. REV. 739 (1991).

182 See BAKER \& WILLIAMS, supra note *, at 32-41, 53-62. See also CARL L. BECKER, THE DECLARATION OF INDEPENDENCE: A STUDY IN THE HISTORY OF POLITICAL IDEAS (1958); PaUline MaIER, AmERICAN SCRIPTURE: MaKING the DECLARATION OF INDEPENDENCE (1997).

183 See Michael V. Hernandez, A Flawed Foundation: Christianity's Loss of Preeminent Influence on American Law, 56 RUTGERS L. REV. 625, 634-38. 
Framers were Lockeans, not Thomists. ${ }^{184}$ Truth for them came from right reason from the mind of man, not from the Godhead. ${ }^{185}$ They believed that there was a body of ethical imperatives inherent in human beings and discovered by human reason alone. They studied John Locke, who imagined that in a pre-existing state of nature neither civil society nor government existed and each person was sovereign unto himself or herself. ${ }^{186}$ But Thomas Hobbes, another political philosopher who influenced their era, had described life in the state of nature, without government or civil laws, as "solitary, poor, nasty, brutish and short."187 Civil society is called into being by the social contract: individuals consent to government and yield some personal autonomy to society that in turn exercises this sovereignty to protect the individual's right to the pursuit of happiness, including the right to acquire and enjoy property that allowed a person to be independent and free to exercise other rights. The laws of nature, therefore, provide the link between the state of nature and civil society, or between natural rights and government. Government does not grant us rights - we have inalienable, God-given rights. The New World was analogous to the state of nature in the minds of the Founders, and it was incumbent upon them to write a social contract; this covenant theme has a religious origin that evolved into political theory from the Mayflower Compact, through the colonial charters, the Declaration of Independence, and the experience with early constitution-writing in the states leading up to the Constitutional Convention of 1787.

The Declaration of Independence leads to the Constitution because the rights endowed equally in all persons necessarily require a well-governed society to guarantee law and order. The Framers believed that the whole Constitution was a kind of bill of rights that limited the threat against liberty posed by government. ${ }^{188}$ At the time of the Framers, soon after the Constitution was ratified, the Supreme Court debated the idea that judicial review could be exercised to strike down statutes on the basis of natural law. In seriatim opinions, Justice Chase said "yes;" Justice

184 See generally Raoul Berger, Natural Law and Judicial Review: Reflections of an Earthbound Lawyer, 61 U. CIN. L. REV. 5 (1992); William J. Stuntz, Christian Legal Theory, 116 HARV. L. REV. 1707 (2003) (book review).

185 See generally ROBERT LOWRY CLINTON, GOD \& MAN IN THE LAW: THE FOUNDATIONS OF ANGLO-AMERICAN CONSTITUTIONALISM (1997); STEVEN D. SMITH, THE CONSTITUTION AND THE PRIDE OF REASON (1998); ELLIS WASHINGTON, THE INSEPARABILITY OF LAW AND MORALTTY: THE CONSTITUTION, NATURAL LAW, AND THE RULE OF LAW (2002).

${ }^{186}$ Seegenerally DavidL. Wardle,ReasontoRatify:The InfluenceofJohnLocke'sReligious Beliefs on the Creation and Adoption of the United States Constitution, 26 SEATTLE U. L. REV. 291 (2002).

187 ThOMAS HobBes, LeVIATHAN 186 (Penguin Books 1985) (1651).

188 "The truth is ... that the Constitution is itself, in every rational sense, and to every useful purpose, a bill of rights." THE FEDERALIST No. 84, at 515 (Alexander Hamilton) (Clinton Rossiter ed., 1961). 
Iredell said "no."189 In theory, the Supreme Court has followed Justice Iredell, basing its decisions only on formal legal interpretations of the Constitution. In practice, the Court's interpretations of the Constitution often seem to have a great deal to do with norms and values the Justices read into the text.

In our time, Princeton political scientist Walter Murphy insists that in a postFreudian world there can be no naive denial that a judge's personal values and life experiences influence the way the judge interprets the Constitution and decides cases. ${ }^{190}$ There is a spirited debate among academics and jurists, however, over the propriety of a judge overtly relying on political philosophy or moral reasoning.

Ronald Dworkin, who teaches at New York University and Oxford University, is a leading proponent of a moral reading of the Constitution. ${ }^{191} \mathrm{He}$ insists that the value-laden discourse of constitutional law, on the part of "liberals" and "conservatives" alike, takes place within a moral context of political decency and ultimate justice. Nothing else would be true to the rule of law. The Framers meant the Constitution to codify and enact general principles - what he calls "concepts" of right and wrong - but they did not intend for subsequent generations to adhere to their particular views on specific issues, or their "conceptions" of specific policies. This is the only way to avoid the Scylla and Charybdis of majoritarianism and being ruled by the dead hand of the past. Wake Forest's Michael Perry would go even further and embrace the indeterminacy of moral reasoning as the ultimate justification for judging, i.e., that judges exercise discernment and judgment to interpret the Constitution and decide cases. ${ }^{192} \mathrm{He}$ would welcome and celebrate a judge's reliance on the judge's own personal beliefs. Consequently, both of these scholars would place a great emphasis on the importance of judicial selection to vet and choose judges who are wise and fair and principled members of the elite interpretive community. ${ }^{193}$

189 Calder v. Bull, 3 U.S. (3 Dall.) 386 (1798).

190

In a post-Freudian world, there can be no serious doubt that a judge's ... personal values influence the way in which he or she interprets the Constitution. Society can require that judges be neutral between parties to a case; but no one can ask a mature adult to be neutral between ideas that to the heart of political philosophy. Not only do we all carry the effects of early childhood, religious and moral instruction, family relations, and social class, but we are affected by our more formal education and our experiences through life.

WALTER F. MURPHY ET AL., AMERICANCONSTITUTIONAL. INTERPRETATION 61 (1 st ed. 1986). See also Laura Kalman, Does Character Affect Judicial Performance?, 71 U. CoLo. L. REv. 1385 (2000).

191 Ronald DWORKIN, FreEdom's LAW: THE MORAL READING OF THE AMERICAN CONSTITUTION (1996).

192 Michael J. Perry, MoraltTy, Polttics, and Law: A Bi-Centennial EsSay (1988).

193 A recent article has proposed that Supreme Court Justices be selected "scientifically" from among active judges, but the President and the Senate are not likely to forego their historic prerogatives in favor of some reality-based TV format. See Stephen Choi \& Mitu 
Michael McConnell, of the University of Utah and now a judge on the United States Court of Appeals for the Tenth Circuit, is highly critical of this approach to constitutional interpretation. ${ }^{194} \mathrm{He}$ sees but three logical alternatives: (1) to read the Constitution in light of the Framers' expectations about specific applications; (2) to read the Constitution in light of the moral and political principles they intended to express; or (3) to read the Constitution in light of what we now think would be the best way to understand the abstract language. An originalist who seeks the original understanding of the Constitution, McConnell says that only the second alternative is proper. He thus lines up with Justices Scalia and Thomas on the current Supreme Court. The first alternative folds to the dead hand of the past. The third alternative - the approach Dworkin and Perry endorse - would, for all intents and purposes, turn over the Constitution to the power of the judges. But judges are men and women - not angels - and in designing a constitutional government, James Madison warned us to be mistrustful of what power does to men and women. ${ }^{195}$

Whether Dworkin and Perry or McConnell has the better argument is left to the reader. As with other interpretative methodologies, your preference really depends on what kind of Constitution - and what kind of Supreme Court - you believe we should have. Justice Brennan, the chief proponent of moral reasoning in constitutional interpretation while he was on the Supreme Court, answered those questions this way:

We current Justices read the Constitution in the only way that we can: as Twentieth-Century Americans. We look to the history

Gulati, A Tournament of Judges?, 92 CALIF. L. REV. 299 (2004). See also Ronald C. Den Otter, The Place of Moral Judgment in Constitutional Interpretation, 37 IND. L. REV. 375 (2004).

194 Michael W. McConnell, The Importance of Humility in Judicial Review: A Comment on Ronald Dworkin's “Moral Reading” of the Constitution, 65 FORDHAM L. REV. 1269 (1997). See also Larty Alexander, “With Me, It's All er Nuthin"': Formalism in Law and Morality, 66 U. CHI. L. REV. 530 (1999); Edward O. Correia, Moral Reasoning and the Due Process Clause, 3 S. CAL. INTERDISC. L.J. 529 (1994); Michael D. Daneker, Moral Reasoning and the Quest for Legitimacy, 43 AM. U. L. REV. 49 (1993).

195 It may be a reflection on human nature that such devices should be necessary to control the abuses of government. But what is government itself but the greatest of all reflections on human nature? If men were : $\quad$ angels, no government would be necessary. If angels were to govern men, neither external nor internal controls on government would be necessary. In framing a government which is to be administered by men over men, the great difficulty lies in this: you must first enable the government to control the governed; and in the next place oblige it to control itself.

The Federalist No. 51, at 322 (James Madison) (Clinton Rossiter ed., 1961). See generally SCOTT GORDON, CONTROLIING THE STATES: CONSTITUTIONALISM FROM ANCIENT ATHENS TO TODAY (1999). 
of the time of framing and to the intervening history of interpretation. But the ultimate question must be, what do the words of the text mean in our time? For the genius of the Constitution rests not in any static meaning it might have had in a world that is dead and gone, but in the adaptability of its great principles to cope with current problems and current needs. What the constitutional fundamentals meant to the wisdom of other times cannot be their measure to the vision of our time. Similarly, what those fundamentals mean for us, our descendants will learn, cannot be the measure to the vision of their time. ${ }^{196}$

\section{HOW TO INTERPRET THE CONSTITUTION?}

As has been just described, the available and most prevalent sources of meaning for interpreting the Constitution are the text, original understanding, history and tradition, structure, precedent or doctrine, and philosophy or moral reasoning. Constitutional interpretation is characterized by an intellectual syncretism that relies on these sources to varying degrees and often in combination. ${ }^{197}$ Different interpreters rely on different sources, and often they differ in approach, emphasis, and outcomes. Even the same individual interpreter will sometimes use different sources to analyze different constitutional questions. ${ }^{198}$ Nonetheless, Harvard's Richard Fallon maintains that it is highly desirable and readily feasible for a constitutional interpreter to be coherent and consistent by striving for some measure of commensurability to fit together and weigh against each other these various sources of constitutional meaning. ${ }^{199}$

Interpreters can be situated along three continuums based on their fundamental orientation and understanding of the Constitution and how they go about interpret-

196 William J. Brennan, Jr., The Constitution of the United States: Contemporary Ratification, in INTERPRETING THE CONSTITUTION: THE DEBATE OVER ORIGINAL INTENT at 23, 27 (Jack N. Rakove ed., 1990). See generally Hunter R. Clark, Justice Brennan: The Great Conciliator (1995); Frank I. MiChElman, BrenNan AND DEMOCRACY (1999); Stephen L. Sepinuck \& Mary Pat Treuthart, The Conscience of the Court: SElected Opinions of Justice William J. Brennan, JR. ON Freedom aNd Equality (1999).

197 See PHILIP BOBBITT, CONSTITUTIONAL INTERPRETATION 11-22 (1991).

198 Richard A. Champagne, Jr., The Problem of Integrity, Tradition, and Text in Constitutional Interpretation, 72 NEB. L. REV. 78 (1993).

199 Richard H. Fallon, Jr., A Constructivist Coherence Theory of Constitutional Interpretation, 100 HARV. L. REV. 1189 (1987). See also Michael C. Dorf, Integrating Normative and Descriptive Constitutional Theory: The Case of Original Meaning, 85 GEO. L.J. 1765 (1997). 
ing the Constitution. ${ }^{200}$ One continuum runs between those interpreters who emphasize textualism and those who emphasize transcendence. This is closely related to the previously-discussed question, "What Is the Constitution?"201 Is it the text and only the text, or is it the document plus other sources of transcendent meaning that might be gleaned from various sources beyond the text: other formative documents like the Declaration of Independence, historical understandings, philosophical principles from political philosophy and democratic theory? A second continuum of interpreters lies between those who understand the Constitution to be fixed in time and meaning and those who understand it to be changing and evolving. And changes might include not just textual amendments and Supreme Court precedents, but also the changed circumstances and needs of contemporary times. A third continuum of interpreters distinguishes between those who understand the Constitution as a set of rules and those who understand the Constitution to radiate aspirations and values, like human dignity and individual autonomy. The former emphasize that the Constitution is the written embodiment of the rule of law that restricts government; the latter emphasize the spirit of the Constitution that animates government. Where an interpreter is located on these continuums will help determine how the interpreter sorts through the various available sources of meaning. An interpreter located at one end of these continuums, who understands the Constitution to be more textual than transcendent, more fixed than changing, and more rules than vision, will be stuck in a verbal analysis that focuses on the plain meaning of the Constitution. By comparison, an interpreter located at the other end of these three continuums, who understands the Constitution to be transcendent, evolving, and aspirational will not tarry long over its actual wording, but rather will pursue higher constitutional philosophy.

\section{A. A Meta-Theory Example}

It seems as if every con law prof and every Supreme Court Justice has a different theory of constitutional interpretation. Meta-theory - the theory a level of abstraction above theory that seeks to organize the theorists into a conversation and attempts to compare and contrast their theorizing - is also highly-contested and remarkably jargonized. Describing one of the meta-theories will nicely illustrate my thesis that how one interprets the Constitution is more of an art than a science. (Law students are advised that this sample meta-theory is how "poli sci profs" think about constitutional interpretation. So this part "will not be on the exam." $)^{202}$ Professors

${ }^{200}$ MURPHY ET AL., supra note 190, at 290-91.

201 See supra Part III.

202 See generally Daniel N. Hoffman, OUR Elusive Constitution: Silences, PARADOXES, PRIORITIES (1997); SOTIRIOS A. BARBER, ON WhAT THE CONSTITUTION MEANS (1984); Ronald Kahn, 'The Canon' of Constitutional Law for Undergraduate Teaching: The 
Murphy, Flemming, Barber, and Macedo, four leading political science professors, offer a detailed, elaborate, self-contained, book-length typology or taxonomy of "approaches" to constitutional interpretation. ${ }^{203}$

Those four political scientists define an "approach" to interpretation as being "the intellectual path (or paths) an interpreter follows to seek meaning" from the Constitution. ${ }^{204}$ Approaches overlap and interpreters combine them. Of course, how an interpreter answers the question "How to interpret the Constitution?" is closely related to the question "Who interprets the Constitution?"205 and the question "What is the Constitution?"206 Professors Murphy, Flemming, Barber, and Macedo identify and group the most common approaches to constitutional interpretation: textualists, originalists, doctrinalists, developmentalists, philosophes, structuralists, purposivists, aspirationists, and balancers. What follows are brief descriptions to identify how interpreters make use of these nine approaches: a "Field Guide to Constitutional Interpreters."

\section{Textualists}

A textual approach necessarily begins with the text, and most interpreters do so. ${ }^{207}$ Even those interpreters who end up ignoring the text typically take pains to justify doing so. There are a variety of textual approaches, however, and some examples are worth noting briefly. ${ }^{208}$ A "clause-bound textualist" focuses on a particular clause to plumb its meaning. A "structural textualist" scrutinizes a clause in the context of the rest of the text, especially any closely related clauses. A "purposive textualist" seeks to articulate the purpose or goal behind a clause, i.e., the underlying principle. Nonetheless, "textualism has a paradoxical quality: all approaches to constitutional meaning are textual because the Constitution is a text,

Melding of Constitutional Theory, Law, and Interpretative/Empirical Political Science, 17 CONST. COMMENT. 399 (2000).

${ }^{203}$ MURPHY ET AL., supra note 2, at 385-444. The first edition of this casebook put forward the somewhat different typology of a three-tiered model that included "approaches to interpretation," "modes of analysis," and "analytical techniques." "Approaches" referred to the basic way an interpreter understands the Constitution. "Modes" referred to how an interpreter uses those approaches to interpret the Constitution. "Techniques" designated specific tools used to interpret the Constitution. MURPHY ET AL., supra note 190, at 289-318.

${ }^{204}$ MURPHY ET AL., supra note 2, at 389. The reader is referred to their casebook for further elaborations of these approaches complete with case examples from the Supreme Court and relevant citations to the scholarly literature. See also supra note 2 (other bibliographic sources).

205 See supra Part II.

${ }^{206}$ See supra Part III.

207 See supra text accompanying notes 64-85.

${ }^{208}$ MURPHY ET AL., supra note 2, at 390-95. 
yet textualism, without more, cannot help us when the text itself is puzzling, which it often is." 209

\section{Originalists}

The approach of originalism has been discussed and so it only needs brief mention here. ${ }^{210}$ Again, originalists come in different shapes and sizes. ${ }^{211}$ Some originalists seek the "original intent," i.e., the meaning the Framers personally and subjectively had in mind - how they would reason about the issue and decide the case. Others search for the "original understanding," i.e., the meaning that a reasonable and informed reader would have afforded the text at the time it was written and ratified. For an originalist, the text has a meaning independent and apart from the interpreter's personal preferences and predilections. Originalists purport to prefer the wisdom of the Framers over their own. ${ }^{212}$ The approach takes more faith today than it did back in John Marshall's day, when he essentially was deferring to himself and his friends. ${ }^{213}$ Originalism thus appeals to the rhadamanthine mind.

\section{Doctrinalists}

Constitutional law doctrine also has already been discussed. ${ }^{214}$ The interpretative approach of doctrinalism basically contemplates "past interpretations as they relate to specific problems ... and tries to organize them into a coherent whole and fit the solution of current problems into that whole."215 Precedent or stare decisis fits here too. ${ }^{216}$ Supreme Court opinions articulate constitutional law doctrines to implement the language of the Constitution. Supreme Court opinions are full of various multiple-part tests, factorial analyses, levels of scrutiny, tiers of analyses, et cetera, that provide rules for decisions. A common move of exasperation, but a false move of constitutional theory, is for a dissenting Justice to rant about how the majority's legal doctrine is not to be found in the text of the Constitution. Duh! $!^{217}$

\footnotetext{
209 Id. at 393.

210 See supra text accompanying notes 86-104.

211 MURPHY ET AL., supra note 2, at 395-405.

212 Justice Scalia once mockingly announced that he would be indifferent between the personal judgment of the nine Justices of the Supreme Court of the United States and nine people picked at random from a phonebook. Cruzan v. Dir., Mo. Dep't of Health, 497 U.S. 261, 293 (1990) (Scalia, J., concurring).

213 Murphy et AL., American Constitutional InTERPRetation 393 (2d ed. 1995).

214 See supra text accompanying notes 148-80.

215 MURPHY ET AL., supra note 2, at 406.

216 See supra text accompanying notes 151-74.

217 "Were this a true concern, we would have to abandon most of our constitutional
} 
That is the whole point of judge-made doctrine - to mediate the conceptual distance between a general clause in the Constitution and a ruling for one side or the other in a particular case or controversy. For example, doctrine is how we get from the "due process of law" clauses in the Fifth and Fourteenth Amendments to actually deciding whether persons who are being deprived of their government benefits are entitled to a new hearing. ${ }^{218}$ Whether or not your con law prof is doctrinallyoriented to the subject of Constitutional Law, there is a high probability that the final examination will expect you to make some doctrinal noises and it is certain that your state board of bar examiners will put you through the multiple choice paces on constitutional doctrines on the Multistate Bar Examination. ${ }^{219}$

\section{Developmentalists}

Constitutional developmentalism is an approach to interpretation that "accept[s] the value of incremental additions of judge-made doctrine, but goes further by enlarging the interpretative arena to include broader historical events, such as informal practices, usages, and political culture."220 The emphasis is on resolving contemporary issues with contemporary constitutional understandings that are the product of "past authoritative interpretations by courts and relevant historical

jurisprudence." Webster v. Reprod. Health Servs., 492 U.S. 490, 548 (1989) (Blackmun, J., concurring).

${ }^{218}$ The current doctrine asks and answers two simple questions: first, we ask if the state deprived someone of something that is "life" or "liberty" or "property," and if the answer is "yes," then the second question we ask is "what process is due?" To answer the second question, the Supreme Court's current doctrine weighs: (1) the private interest being affected; (2) the risk of error in the procedures that were followed and the probable value of additional or substitute procedures; and (3) the government's interest. Consider the application of the doctrine in two leading cases. In Goldberg v. Kelly, 397 U.S. 254 (1970), the Court held that a state had to hold a pre-termination hearing and provide a quasi-judicial evidentiary hearing before cutting off public assistance payments to a welfare recipient. In Mathews v. Eldridge, 424 U.S. 319 (1976), the Court held that a less formal hearing was adequate procedure for the termination of Social Security disability benefits because the nature of the determination was essentially a medical decision that was based on written evidence and medical reports. The first factor is almost always on the individual's side in favor of earlier and more procedures. The third factor is mostly on the government's side in favor of lesser and later procedures. The second factor can break either way, depending on the nature of the interest at stake. These three factors are not the be-all or end-all of due process analysis, however, as the Court has proclaimed that the "straightforward test of reasonableness under the circumstances" is the ultimate measure of procedural fairness. Dusenbery v. United States, 534 U.S. 161, 167 (2002).

${ }_{219}$ See National Conference of Bar Examiners, Multistate Bar Examination Subject Matter Outlines - Constitutional Law, at http://www.ncbex.org/tests.htm (last visited Nov. 9, 2004).

${ }^{220}$ MURPHY ET AL., supra note 2, at 410. 
changes in the broader political culture."221 This approach normatively plays out in a polarized debate between those who try to keep the Constitution in tune with the times and those who try to keep the times in tune with the Constitution. ${ }^{222}$

\section{Philosophes}

As we have seen, ${ }^{223}$ the philosophical approach to constitutional interpretation

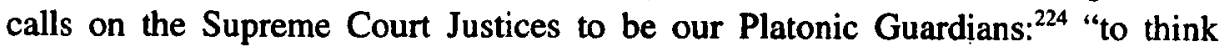
critically about the best meaning of [constitutional] prohibitions or requirements, and to justify these judgments to others ... to articulate and rely upon critical moral judgments not just in choosing among interpretative strategies, but as part of interpretation itself."225 You should not overlook that your casebook and your con law prof, following the Supreme Court's own provocative lead, emphasize and focus on matters of philosophical and moral disagreement, such as abortion, rather than on matters of fundamental agreement and national consensus, such as our basic civil rights, civil liberties, and governmental institutions. ${ }^{226}$

\section{Structuralists}

Professors Murphy, Flemming, Barber, and Macedo would refine what was said earlier about structuralism ${ }^{227}$ to urge that we must more fully appreciate how constitutional meaning, to decide important cases, can be derived subtly and indirectly from the Constitution's own textual organization and, more importantly,

221

222

Id. at 412 .

I realize that many good and able men have eloquently spoken and written, sometimes in rhapsodical strains, about the duty of this Court to keep the Constitution in tune with the times. The idea is that the Constitution must be changed from time to time and that this Court is charged with a duty to make those changes. For myself, I must with all deference reject that philosophy. The Constitution makers knew the need for change and provided for it. Amendments suggested by the people's elected representatives can be submitted to the people or their selected agents for ratification. That method of change was good for our Fathers, and being somewhat old-fashioned I must add it is good enough for me.

Griswold v. Connecticut, 381 U.S. 479, 522 (1965) (Black, J., dissenting).

223 See supra text accompanying notes 182-96.

224 "For myself it would be most irksome to be ruled by a bevy of Platonic Guardians, even if I knew how to choose them, which I assuredly do not." LEARNED HAND, THE BILL OF RIGHTS 73 (1958). Of course, Judge Hand never got to sit on the Supreme Court.

225 MURPHY ET AL., supra note 2, at 415.

226

Id.

227 See supra text accompanying notes $123-43$. 
from the political organization the document imposes on the government by creating the three federal branches and their offices and by ordering their interrelationships, as well as by ordering the elaborate relationship between the national government and the states in the Union. ${ }^{228}$ Thus, the principal structural ideas of the Constitution - for example, the separation of powers, checks and balances, and federalism - are not provided for in so many words but are inherent in the design and function of the Constitution. ${ }^{229}$ Indeed, in the course of constitutional interpretation, it is impossible to avoid making and relying on structural arguments. ${ }^{230}$ The Constitution is intended to create and maintain a political unity.

\section{Purposivists}

The Constitution is not an end in itself, but rather a means to some higher ends, and the purposive approach to constitutional interpretation has sought to identify and implement the basic and profound purposes of our system of government. ${ }^{231}$ Different styles of purposive analysis dictate different styles of judicial review of actions by the democratic or elected branches. A purposivist interpreter who follows "the doctrine of clear mistake" relies on democratic theory and expects judges to defer to the majoritarian political process and therefore uphold policies and statutes unless a violation of the Constitution is obvious and beyond doubt. ${ }^{232} \mathrm{~A}$ purposivist who seeks an interpretive approach to "reinforce representative democracy" also would defer to political decisions of legislatures and generally afford them a presumption of constitutionality, except when political majorities cannot be trusted, when they infringe on constitutional rights, restrict the political processes itself, or act to the prejudice of discrete and insular minorities. ${ }^{233}$ Some purposivist interpreters afford the greatest importance to the role the judicial branch plays in preserving and protecting fundamental rights in individual liberty and autonomy. ${ }^{234}$ Democratic theory and constitutionalism are always running into each other in a purposive approach.

\section{Aspirationalists}

Because there are so many values in play and because there are so many value choices to be made, an interpreter of the Constitution must be imbued with a sense

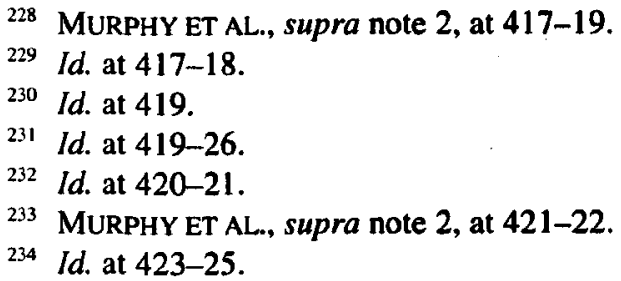


of prudence and of aspiration at the same time. ${ }^{235}$ The constitutional interpreter must be prudent to practice statecraft to set out to govern the policy wisely and pragmatically for the common good, "[not] for saints in a heaven on earth but as practical guidelines for a flawed people in a flawed world." ${ }^{236}$ The constitutional interpreter must also have a sense of appreciation for the aspirational nature of the Constitution; that it is "more than a set of rules for government but has, as the Preamble states, certain goals that point the nation toward an attainable good life, or a realizable vision of justice."237

\section{Balancers}

One more interpretative approach that is regularly used by various Justices is balancing. ${ }^{238}$ The metaphor is borrowed from the familiar figure of the blindfolded goddess of justice holding a set of scales to weigh the opposing claims to decide a dispute. ${ }^{239}$ Balancing two constitutional values in conflict, as when the Court balances an individual's right to associate against a group's right not to associate with the individual, is one form. ${ }^{240}$ Another form of the metaphor is to balance individual liberty against government power, which is the fundamental, irreducible issue of all constitutional analysis. ${ }^{241}$ But balancing can amount to little more than a conclusion or a stated preference: "we find in favor of the individual and against the government" does not reveal much analysis. Taken at face value, it is a Skinnerian black box, a verbal sleight of hand to divert our attention. Taking the metaphor literally, we would expect the judge to carefully assay the individual liberty and the government power and assign each a calibrated value in order to

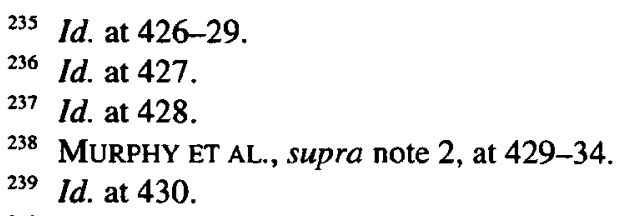

240 Sometimes the individual right to associate is upheld against an invocation of government power, and sometimes the individual right not to associate is upheld against the invocation of government power. But sometimes the Constitution recognizes a government power to regulate associational rights and trump a claim of the right to associate or not to associate. E.g., Boy Scouts of Am. v. Dale, 530 U.S. 640 (2000) (holding that forcing the Boy Scouts to accept a homosexual member violated their freedom of association); Hurley v. Irish-Am. Gay, Lesbian \& Bisexual Group, Inc., 515 U.S. 557 (1995) (holding that forcing citizens who organize parade to include openly gay individuals violated their freedom of association); Bd. of Dirs. of Rotary Int'1 v. Rotary Club, 481 U.S. 537 (1987) (holding that club interest not to associate was outweighed by compelling state interest in eliminating gender discrimination and in assuring equal access to public accommodations); Roberts v. U.S. Jaycees, 468 U.S. 609 (1984). See generally BAKER \& WILLIAMS, supra note *, at 168-74.

${ }^{241}$ See generally BAKER \& WILLIAMS, supra note *, at 92-132. 
balance them: "the individual liberty is worth five utils and the government power is worth three utils so the government loses this case by two utils." But you will never read that in an opinion. ${ }^{242}$ For some constitutional issues, balancing is required by the text itself, as, for example, the Fourth Amendment, which forbids only "unreasonable" searches and seizures, ${ }^{243}$ or the Eighth Amendment, which prohibits "excessive fines" and "cruel and unusual punishments." 244 Many Justices generalize this balancing approach in their jurisprudence to prefer standards, as opposed to rules, for deciding constitutional cases. A simple example of a standard is "drive at a safe speed," and a simple example of a comparable rule is "do not exceed 55 m.p.h." Kathleen Sullivan, Dean of Stanford Law School, chronicled how this methodological difference accounted for some of the strongest disagreements among the Justices on the Rehnquist Court. ${ }^{245}$ Justice O'Connor is fond of totality-of-the-circumstances analysis, applying a general standard such as whether a statute interferes "too much" with the Constitution. ${ }^{246}$ On the other hand, Justice Scalia has ridiculed balancing as an approach to constitutional interpretation by complaining that "the scale analogy is not really appropriate, since the interests on both sides are incommensurate. It is more like judging whether a particular line is longer than a particular rock is heavy."247 Our constitutional analysis obliges the Court to find the balance of individual liberty and government power in the Constitution, however, by defining the scope of the liberty and the reach of the power on an ongoing basis. This approach is more than some simplistic "balancing" test that announces nothing more than the subjective preference of a majority of five about who should win and who should lose. The standard operating methodology the Court relies on the most in our constitutional analysis is doctrine or precedent, which is considerably elaborate and full of nuance, as we have duly noted in our discussions of doctrine. ${ }^{248}$ All those three-part tests and four-prong analyses in Supreme Court opinions are properly understood as variations of the balancing approach to interpretation; the Justices use these tests to call on lower court judges

242 Justice Cardozo, a great judge and an insightful commentator on judging, tellingly admitted: "If you ask how [a judge] is to know when one interest outweighs another, I can only answer that he must get his knowledge just as the legislator gets it, from experience and study and reflection; in brief, from life itself." BENJAMIN N. CARDOZO, THE NATURE OF THE JUDICIAL PROCESS 113 (1921).

243 U.S. CONST. amend. IV.

244 U.S. CONST. amend. VIII.

245 Kathleen M. Sullivan, Foreword: The Justices of Rules and Standards, 106 HARV. L. REV. 22 (1992).

246 See, e.g., Georgia v. Ashcroft, 539 U.S. 461, 484-85 (2003) (Justice O'Connor writing for the Court, applying the totality-of-the-circumstances test to a challenge to the Georgia State Senate's redistricting plan, predicated on $\$ 5$ of the Voting Rights Act of 1965).

247 Bendix Autolite Corp. v. Midwesco Enters., Inc., 486 U.S. 888, 897 (1988) (Scalia, J., concurring).

${ }^{248}$ See supra text accompanying notes $148-80,214-19$. 
to do the balancing in the first place in the application of the identified factors always subject to appellate review. ${ }^{249}$

\section{False Dichotomies}

There are a couple of snipe hunts in constitutional theory which are worth a brief mention here that amount to false dichotomies. ${ }^{250}$ Although they are a familiar part of the constitutional discourse, these false dichotomies really do not withstand a closer intellectual scrutiny. They are meaningless, for all intents and purposes. Consider "strict construction" and "liberal construction." ${ }^{\text {"251 }}$ When a Court interprets individual liberty strictly, then correspondingly it is interpreting government power liberally, and vice versa. So what really is the point of the distinction? How does an interpreter interpret strictly or liberally in the first place? What does a President mean to say that an ideal judge is a "strict constructionist"? "Judicial activism" and "judicial self-restraint," like beauty, are in the eyes of the beholder. ${ }^{252}$ When they get out-voted, dissenters use those terms to distinguish themselves from the majority. It is not activism to enforce the Constitution; it is not self-restraint to refrain from enforcing the Constitution; it is simply enforcing or not enforcing the Constitution. ${ }^{253}$ Also consider the Due Process Clauses and the distinction between "substance" and "procedure."254 Only a lawyer's mind could come up with the distinction between a logical redundancy and a logical contradiction: between "procedural due process" (process-process!) and "substantive due process" (substantive-process!). All of constitutional law is substantive except for procedural due process, but procedural due process concerns the fundamental fairness in providing adequate notice and a reasonable opportunity to be heard. That idea of fairness is a substantive value. Finally, the scholarly literature used to make much of the distinction between "interpretivists" and "non-interpretivists." But even Thomas Grey, the Stanford professor who started all of us talking about interpreters along those lines has given up to admit that we all are interpretivists and we all are non-interpretivists. ${ }^{255}$ Everyone always starts with the text, and everyone goes

249 The three-part definition of obscenity, that separates protected and unprotected speech under the First and Fourteenth Amendments, is a good example. Jenkins v. Georgia, 418 U.S. 153 (1974); Miller v. California, 413 U.S. 15, 24 (1973).

250 See generally MURPHY ET AL., supra note 2, at 436-39.

251 Id. at $436-37$.

252 Id. at 437.

253 The dichotomy between judicial restraint and judicial activism is not a characteristic of a judge's orientation to the court as an institution or to the principle of precedent; it is a characteristic of the judge's orientation of the role of courts to the rest of society. See Richard A. Posner, The Meaning of Judicial Self-Restraint, 59 IND. L.J. 1 (1983).

254 MURPHY ET AL., supra note 2, at 437.

255 Thomas C. Grey, The Constitution as Scripture, 37 STAN. L. REV. 1 (1984). See also 
beyond the text sometimes. Anyone who does not do both is more than eccentric. Pay particular attention if your con law prof happens to be eccentric.

Even these brief profiles of the nine common types of interpreters and their approaches to constitutional interpretation - textualists, originalists, doctrinalists, developmentalists, philosophes, structuralists, purposivists, aspirationalists, and balancers - provide some appreciation of how abstract and subtle these approaches can be and how they might be in conflict, one with the others. Is it any wonder that so many students of the subject find it daunting for its complexity and controversy? ? $^{256}$ Professors Murphy, Flemming, Barber, and Macedo try to be encouraging: "Being self-aware about the sources of interpretation and the inevitability of normative judgment should allow us frankly to confront important and unavoidable questions more directly and more clearly, and, we hope, more reflectively and responsibly."257 Sure.

As you read the Supreme Court opinions, which are arranged for the most part doctrinally in your casebook, the fact that there are fashions and trends in constitutional theory should not be lost on you. That all the various approaches to how to interpret the Constitution are exemplified in Supreme Court jurisprudence - can be suggested by a paragraph recap of the last half century. ${ }^{258}$ During the Chief Justiceship of Earl Warren, ${ }^{259}$ the Justices behaved like phlilosophes to rely on moral reasoning in important cases, striving purposively to reach the "right result." They found the value for the school desegregation case ${ }^{260}$ chiseled in the pediment on the front of their building: "Equal Justice Under Law." Those Justices also invested the Court's prestige to reform government processes: reapportioning state legislatures ${ }^{261}$ and reforming the criminal justice system. ${ }^{262}$ They practiced a lot of clause-bound interpretivism, focusing on the "right to Counsel" in the Sixth Amendment, for example, and then used the common law methodology to build up a considerable body of case annotations. ${ }^{263}$ Following suit, the Burger Court ${ }^{264}$ worked over a lot

Michael S. Moore, The Interpretive Turn in Modern Theory: A Turn for the Worse?, 41 STAN. L. REV. 871 (1989).

256 MURPHY ET AL., supra note 2, at 435.

257 Id.

258 "The literature about the Supreme Court is vast - and fascinating." WRIGHT \& KANE, supra note 34, at 14 n.1. See generally BAKER, supra note 34, at 179-85; Baker, supra note 6.

259 See generally LuCAS A. POWE, JR., The WarRen COURT AND AMERICAN POLITICS (2000); THE WARREN COURT IN Historical AND PoltTiCal PERSPECTIVE (Mark Tushnet ed., 1993).

${ }^{260}$ E.g., Brown v.Bd.ofEduc., 347U.S.483(1954). See generally John E. Nowak, The Rise and Fallof Supreme Court ConcernforRacialMinorities, 36 WM.\&MARYL.REV.345(1995).

261 E.g., Reynolds v. Sims, 377 U.S. 533 (1964).

262 E.g., Miranda v. Arizona, 384 U.S. 436 (1966).

${ }^{263}$ E.g., Ake v. Oklahoma, 470 U.S. 68 (1985); Williams v. Illinois, 399 U.S. 235 (1970); Gideon v. Wainwright, 372 U.S. 335 (1963).

264 See generally THE BuRger Court: THE COUNTER-REVOlution THAT WASN'T 
of precedents and doctrine, usually distinguishing the hell out of Warren Court opinions. ${ }^{265}$ Those Justices grew the nontextual "right to privacy"266 and made the states redo their capital punishment laws. ${ }^{267}$ The Rehnquist Court ${ }^{268}$ presided over what likely will go down in history as the heyday of originalism. Even nonoriginalist Justices on the Court wrote opinions full of historical references and relied on history and tradition to fill in gaps left by the Framers. ${ }^{269}$ Those Justices were somewhat ambivalent about the nontextual right of privacy: ${ }^{270}$ they qualified the right to an abortion, ${ }^{271}$ and they refused to create a right to euthanasia, ${ }^{272}$ but then they reversed directions to afford constitutional protection to the sexual rights of gays and lesbians. ${ }^{273}$ A closely-divided Court pursued structuralism to decide numerous cases based on separation of powers ${ }^{274}$ and federalism, ${ }^{275}$ in which cases the majority usually sided against Congress and with the states but always protected the judicial prerogative. $^{276}$

During these three judicial eras, however, all the standard sources of constitutional meaning were brought down off the shelf at one time or another and the individual Justices followed their individual interpretative instincts to influence how

(Vincent Blasi ed., 1983); THE BURGER COURT:COUNTER-REVOLUTION OR CONFIRMATION? (Bernard Schwartz ed., 1998).

${ }^{265}$ See, e.g., Jackson v. Metropolitan Edison Co., 419 U.S. 345 (1974).

${ }^{266}$ E.g., Roe v. Wade, 410 U.S. 113 (1973).

${ }^{267}$ E.g., Gregg v. Georgia, 428 U.S. 153 (1976); Furman v. Georgia, 408 U.S. 238 (1972).

268 See generally THE REHNQUIST COURT: JUDICIAL ACTIVISM ON THE RIGHT (Herman Schwartz ed., 2002); TINSLEY E. Yarbrough, THE REHNQUIST COURT AND THE CONSTITUTION (2000).

${ }^{269}$ E.g., U.S. Term Limits, Inc. v. Thornton, 514 U.S. 779 (1995). See also Barnett, supra note 87; Eric J. Segall, A Century Lost: The End of the Originalism Debate, 15 CONST. COMMENT. 411 (1998).

${ }^{270}$ See generally Scott $\mathrm{P}$. Johnson \& Robert M. Alexander, The Rehnquist Court and the Devolution of the Right to Privacy, 105 W. VA. L. REV. 621 (2003).

27 E.g., Planned Parenthood v. Casey, 505 U.S. 833 (1992). See generally Michael J. Gerhardt, The Pressure of Precedent: A Critique of the Conservative Approaches to Stare Decisis in Abortion Cases, 10 CONST. COMMENT. 67 (1993).

272 See, e.g., Washington v. Glucksberg, 521 U.S. 702 (1997); Vacco v. Quill, 521 U.S. 793 (1997).

${ }^{273}$ Lawrence v. Texas, 539 U.S. 558 (2003) (overruling Bowers v. Hardwick, 478 U.S. $186(1986))$.

${ }^{274}$ E.g., Clinton v. City of New York, 524 U.S. 417 (1998); Morrison v. Olson, 487 U.S. 654 (1988); Mistretta v. United States, 488 U.S. 361 (1989).

${ }^{275}$ E.g., Alden v. Maine, 527 U.S. 706 (1999); Coll. Sav. Bank v. Fla. Prepaid Postsecondary Educ. Expense Bd., 527 U.S. 666 (1999); Fla. Prepaid Post-secondary Educ. Expense Bd. v. Coll. Sav. Bank, 527 U.S. 627 (1999); Seminole Tribe v. Florida, 517 U.S. 44 (1996). Ernest A. Young, Alden v. Maine and the Jurisprudence of Structure, 41 WM. \& MARY L. REV. 1601 (2000).

${ }^{276}$ E.g., City of Boerne v. Flores, 521 U.S. 507 (1997); Plaut v. Spendthrift Farm, Inc., 514 U.S. 211 (1995). 
each other thought and wrote about the Constitution. ${ }^{277}$ The University of Chicago's Cass Sunstein has written about the same phenomenon among professors in the universities - following the latest fashions in academic theory. ${ }^{278}$ I might suggest a pretty good test for any interpretive theory is to ask how it would have decided modern landmark decisions that went beyond the limits of theory at the time they were decided. ${ }^{279}$ Doing so provides useful insights about the theoretical approach and its implications for constitutional law.

Finally, consider this significant conceptual paradox about constitutional interpretation: short of a formal constitutional amendment, constitutional change is only possible, and therefore logically we can debate the soundness of constitutional holdings and the persuasiveness of the constitutional reasoning in Supreme Court opinions, if and only if we believe that there actually is a difference, at least in theory, between the Constitution and what the Justices say it is. Next, we will turn our attention to explaining what the prominent contemporary schools of legal philosophy have to say about constitutional law: ${ }^{280}$ liberal theory; conservative theory; feminist theory; critical race theory; and postmodern theory. These different schools believe that there are often significant discontinuities between the Constitution and the Supreme Court's constitutional jurisprudence, but these different schools have different Alphas and Omegas.

\section{LIBERAL THEORY}

The philosophy of liberalism is rooted in the Enlightenment with its emphasis on the rights-bearing individual. Liberal political theory calls the state into existence, and the citizen needs the state to protect individual rights. The state, at the same time, represents the greatest threat to the realization and enjoyment of our rights. The Framers were followers of John Locke, and their liberal constitutionalism depended

27 See generally RONALD KAHN, THE SUPREME COURT AND CONSTITUTIONAL THEORY, 1953-1993 (1994); BERNARd SCHWARTZ, A History OF THE SUPREME COURT (1993); Kenneth W. STaRr, First AMong Equals: The Supreme Court IN AMERICAN LIFE (2002); R. Randall Kelso, Styles of Constitutional Interpretation and the Four Main Approaches to Constitutional Interpretation in American Legal History, 29 VAL. U. L. REV. 121 (1994).

278 Cass R. Sunstein, Foreword: On Academic Fads and Fashions, 99 MICH. L. REV. 1251 (2001). See also Stephen M. Griffin, What is Constitutional Theory? The Newer Theory and the Decline of the Learned Tradition, 62 S. CAL. L. REV. 493 (1989); David A. Strauss, What is Constitutional Theory?, 87 CAL. L. REV. 581 (1999).

279 E.g., Roe v. Wade, 410 U.S. 113 (1973); Brown v. Bd. of Educ., 347 U.S. 483 (1954).

280 See generally MiCHAEL J. GERHARDT ET AL., supra note 2; ROBERT L. HAYMAN, JR. \& NANCY LEVIT, JURISPRUDENCE: CONTEMPORARY READINGS, PROBLEMS, AND NARRATIVES (1994); GARY MINDA, POSTMODERN LEGAL MOVEMENTS: LAW AND JURISPRUDENCE AT CENTURY'S END (1995); SURYA PRAKASH SINHA, JURISPRUdENCE: LEGAL PHILOSOPHY IN A NUTSHELL (1993). 
on rationality to posit a sphere of individual liberty, guaranteed by property rights writ large, with a fixed government constituted by majority consent expressed in regular elections participated in by an enfranchised citizenry. What newspapers today call "liberals" and "conservatives" are all philosophical heirs of the Framers. ${ }^{281}$ Modern constitutional liberalism has followed these assumptions towards the left. ${ }^{282}$

Classical liberal theory dominated the United States in the period between World War II and the end of the twentieth century, and constitutional law was no different. Scott Powe, of the University of Texas, has carefully chronicled how national liberal elite values were dominant in the work product of the Warren Court, usually trumping parochial state and local interests. ${ }^{283}$ Justice Scalia has complained loud and long against a constitutional elitism that he believes animates some recent liberal decisions of an otherwise conservative Supreme Court, ${ }^{284}$ although academic elites have joined issue with him. ${ }^{285}$

Among constitutionalists, there has been considerable evolution within American liberalism. Thomas Grey, of Stanford University, has charted this intellectual family tree to include: the Progressive movement; Legal Realism; Process-based jurisprudence; Civic Republicanism or Neorepublicanism; Critical Legal Studies; Law and Economics; Law and Literature; Feminism with variations; Critical Race Theory with variations; and Pragmatism. ${ }^{286}$ Thus, the political left is a crowded place, full of diversity. It is also a contested space populated by some who insist that they have moved beyond liberalism. Some critical scholars, like Georgetown's Robin West, would be more than ambivalent to be linked with liberalism because they are skeptical whether the values in the Constitution are the right values in the first place. ${ }^{287}$ The farthest-left, most-radical of contemporary political progressives

281 According to The New York Times, for example, the Rehnquist Court is a "conservative" Court some days and a "moderate" Court other days. Compare Linda Greenhouse, Will the Court Move Right? It Already Has, N.Y. TIMES, June 22, 2003, at D3, with Editorial, A Moderate Term on the Court, N.Y. TIMES, June 29, 2003, at D12.

282 See generally SOTIRIOS A. BARBER, THE CONSTITUTION OF JUDICIAL POWER (1993); STEPHEN HOLMES, PASSIONS AND CONSTRAINT: ON THE THEORY OF LIBERAL DEMOCRACY (1995); Kenneth L. Karst, Liberalism, in 4 ENCYCLOPEDIA, supra note 8, at 1613-17.

283 Powe, supra note 259. See also G. EDWARd WhIte, THE CONSTITUTION AND THE NEW DEAL (2000).

${ }^{284}$ Lawrence v. Texas, 539 U.S. 558, 600-05 (2003) (Scalia, J., dissenting); United States v. Virginia, 518 U.S. 515, 600-03 (1996) (Scalia, J., dissenting); Romer v. Evans, 517 U.S. 620, 651-53 (1996) (Scalia, J., dissenting).

285 Symposium: Constitutional Elitism, 30 MCGEORGEL.REv. 95 (1998). See also Robert F. Schopp, Education and Contraception Make Strange Bedfellows: Brown, Griswold, Lochner, and the Putative Dilemma of Liberalism, 32 ARIZ. L. REV. 335 (1990).

286 Thomas Grey, Modern American Legal Thought, 106 YALEL.J. 493 (1996) (reviewing NEIL DUXBURY, PATTERNS OF AMERICAN JURISPRUDENCE (1995)).

${ }^{287}$ Robin L. West, Constitutional Skepticism, 72 B.U. L. REv. 765 (1992). 
tend to view the Constitution with considerable ambivalence and see themselves as skeptics and outliers. ${ }^{288}$

Liberalism shifted emphases between these different paradigms. In the early 1900s, the Progressives picked up where the Populists left off to pursue selfconsciously the betterment of society through legislative agendas informed by principles of social justice and social science. ${ }^{289}$ Then the Legal Realists came along to revitalize social science and support government regulation of the economy and society. ${ }^{290}$ Law was utilitarian, not normative. They saw a central role for judges and courts to arbitrate social disputes, although their insights into judging emphasized how judges were influenced by unconscious attitudes and personal experiences. ${ }^{291}$ The processualists trusted in the economic expertise of the administrative agencies of the New Deal. Their emphasis on procedures played out in the Warren Court's jurisprudence to protect discrete and insular minorities and to reform the political processes in the states. An intellectual ennui with liberalism set in, and after the turbulent 1960s there was a backlash among the cognoscenti. Civic republicans went off in the direction of history to try to recapture the neo-classical values of the Framers, who viewed themselves as the political heirs of the ancient republics of Greece and Rome. ${ }^{292}$ There they found a priority for community and the practice of civic virtue by the individual in the pursuit of the common good. Others took on a critical perspective that turned against the traditional left and went beyond legal realism to deconstruct and criticize liberalism. ${ }^{293}$ There was a loud critique of illegitimate hierarchy and much trashing of traditional understandings about law. But the critical legal studies movement seemed to play itself out in the academy except for its later reflection among feminists and critical race theorists. Nonethe-

288 See generally A LESS THAN PERFECT UNION: ALTERNATIVE PERSPECTIVES ON THE U.S. CONSTITUTION (Jules Lobel ed., 1988).

289 See generally J.M. Balkin, Populism and Progressivism as Constitutional Categories, 104 YALE L.J. 1935 (1995) (reviewing CASS R. SUNSTEIN, DEMOCRACY AND THE PROBLEM of Free Speech (1993)); Gene R. Nichol, Toward a People's Constitution, 91 CAL. L. REV. 621 (2003) (reviewing ROBERT A. DAHL, How DEMOCRATIC IS THE AMERICAN CONSTITUTION? (2001)); Symposium, Is American Progressive Constitutionalism Dead?, 4 WIDENER L. SYMP. J. 229 (1999).

290 See generally AMERICAN LEGAL REALISM (William W. Fisher III et al. eds., 1993).

291 Professor Dorf has called for a return to processualism to imagine different kinds of courts and different kinds of experimental judging. See Michael C. Dorf, Legal Indeterminacy and Institutional Design, 78 N.Y.U. L. REv. 875 (2003).

292 See generally Cass Sunstein, The Partial Constitution (1993); Steven G. Gey, The Unfortunate Revival of Civic Republicanism, 141 U.PA.L. REV. 801 (1993); Symposium, The Republican Civic Tradition, 97 Y ALE L.J. 1493 (1988).

293 See generally ANDREW AltMAN, CRITICAL Legal STUdIES: A LiBERAL CRITIQUE (1990); Critical Legal Studies (James Boyle ed., 1994); MarK KelmaN, A GuIDE TO Critical Legal Studies (1987). 
less, each of these competing liberal paradigms has obvious implications for the Constitution and the role of the Supreme Court. ${ }^{294}$

Laura Kalman, an historian at the University of California at Santa Barbara, has chronicled American legal liberalism which she describes as characterized by a faith in the potential of courts, especially the Supreme Court, to effectuate large scale reforms that improve the situation of underrepresented and oppressed groups. ${ }^{295}$ She zeros in on how law professors, in particular, are prone to join the "cult of the Court" and become judge-worshippers. Thus, conventional liberal con law profs are likely to believe that unregulated markets do not serve the public welfare and that government regulation is necessary to correct unequal distributions of wealth and power. At the same time, those same con law profs would believe that the realm of individual rights must be as free of government interference as possible so that individuals will enjoy the highest level of personal autonomy. Government is to be trusted to pursue this egalitarianism. Their priority has been on civil rights and civil liberties in the larger goal of achieving social justice. They look on the Warren Court with nostalgia and admiration for its halcyon decisions expanding individual rights. The only measure of the Justices' work was how it furthered liberty and equality. But Earl Warren died even before Elvis, and the hopeful who expect the Supreme Court will make a comeback to lead the agenda for radical social change have dwindled to a remnant few true believers.

\section{CONSERVATIVE THEORY}

Just as modern liberalism followed Lockean liberalism to the left, modern conservative constitutional theory followed it to the right. ${ }^{296}$ Like the Framers, modern conservatives are protective of property rights and more comfortable with inequality in wealth and status, at least more so than modern liberals. As was the observation about liberalism, conservative constitutional theory is not monolithic. Conservative jurists and conservative academics generally are drawn to some form of originalism in constitutional interpretation. They tend to be textualists who are mindful of history and tradition more than precedent or doctrine. However, a Burkean conservative, like Professor Ernest Young at the University of Texas, is

294 See generally Mark Tushnet, Constitutional Interpretation, Character, and Experience, 72 B.U. L. REV. 747 (1992).

295 Laura Kalman, The Strange Career of Legal Liberalism (1996). See also SAMUEl WALKER, IN DEFENSE OF AMERICAN LIBERTIES: A HisTORY OF THE ACLU (2d ed. 1990); Mark A. Graber, The Clintonification of American Law: Abortion, Welfare, and Liberal Constitutional Theory, 58 OHIO ST. L.J. 731 (1997).

296 See generally DAVID KAIRYS, WITH LIBERTY AND JUSTICE FOR SOME: A CRITIQUE of the Conservative Supreme Court (1993); Walter Berns, Conservativism, in 2 ENCYCLOPEDLA, supra note 8, at 507-10; Mark Tushnet, Conservative Constitutional Theory, 59 TuL.L.REV.910(1985); J. Harvie WilkinsonIII, Why Conservative Jurisprudence Is Compassionate, 89 VA. L. REV. 753 (2003). 
more accepting of evolutionary common law development and is more attentive to the entire arc of history since the founding and, therefore, far less enamored with originalism. ${ }^{297}$ Conservatives are keenly mistrustful of the liberal egalitarian agenda and far more deferential to majoritarianism than are liberals, although they can be profoundly protective of the judicial prerogative as well. They are skeptical of nontexutal constitutional analysis in the pursuit of individual rights, but at the same time they are keen on nontextual structural interpretation to enforce separation of powers and federalism. The Rehnquist Court is their favorite band - their favorite members are Clarence Thomas, Antonin Scalia, and William H. Rehnquist. ${ }^{298}$

Robert Bork, whose constitutional conservativism cost him a seat on the Supreme Court bench, defined the limited role of the conservative judge:

In a constitutional democracy the moral content of law must be given by the morality of the framer or the legislator, never by the morality of the judge. The sole task of the latter - and it is a task quite large enough for anyone's wisdom, skill, and virtue is to translate the framer's or the legislator's morality into a rule togovern unforeseen circumstances. That abstinence from giving his own desires free play, that continuing and self-conscious renunciation of power, that is the morality of the jurist. ${ }^{299}$

Bork would look on a "liberal judge" relying on moral reasoning and a "conservative judge" relying on natural law with equal suspicion because he believes that both those sources allow judges to find things in the Constitution that are not there, at least not in Bork's constitution. ${ }^{300}$ However, it should be noted that 1,925 law professors (nearly $40 \%$ ) signed on to letters against his nomination for the Supreme Court - a revealing factoid about Bork and about law professors. ${ }^{301}$ Furthermore, some conservative constitutionalists, like historian Harry $\mathrm{Jaffa}^{302}$ and libertarian law

${ }^{297}$ Ernest A. Young, Judicial Activism and Conservative Politics, 73 U. COL. L. REV. 1139 (2002); Ernest Young, Rediscovering Conservativism: Burkean Political Theory and Constitutional Interpretation, 72 N.C. L. REV. 619 (1994).

298 James G. Wilson, Justice Diffused: A Comparison of Edmund Burke's Conservatism with the View of Five Conservative, Academic Judges, 40 U. MIAMI L. REv. 913 (1986).

299 ROBERT H. BORK, TRADITION AND MORALITY IN CONSTITUTIONAL LAW 11 (1984). Bork has written that "constitutional law is useless to study and impossible to teach." Robert H. Bork, The Supreme Court 2000: A Symposium, FIRST THINGS 106 (Oct. 2000).

${ }^{300}$ See id.

301 Hearings on the Nomination of Robert H. Bork to be an Associate Justice of the Supreme Court of the United States Before the Committee on the Judiciary of the United States Senate, 100th Cong., 1st sess., S. Hrg. 100-1011, pt. 1 at 3349 \& 3355-3412 (1987) (statement of Sen. Biden, Chairman and referenced list of law professors).

${ }^{302}$ Harry V. Jaffa, What Were the "Original Intentions" of the Framers of the Constitution of the United States?, 10 U. PUGET SOUND L. REV. 351 (1987). 
professor Randy Barnett, ${ }^{303}$ of Boston University Law School, embrace the idea of natural rights and appeal to the natural law philosophy of the founding to argue the legitimacy of that approach of constitutional interpretation. Bork does have a point, however, to be skeptical about the coincidence that liberals use moral reasoning and conservatives use natural law to find values in the Constitution which somehow share a striking resemblance to the platforms of the Democratic and Republican national parties, respectively. ${ }^{304}$

According to Michael Paulsen, who teaches at the University of Minnesota Law School, some conservative judges are majoritarians who consistently manage to defer to legislatures, but other conservative judges do not always accept that posture. ${ }^{305}$ Conservative jurists with a strong interpretivist approach will follow the text, history and tradition, and structure, even when those sources lead to the invalidation of the legislation. Other conservatives, whose interpretivism is mediated by an instrumentalist sense of constitutional law and the role of the Supreme Court, will take a gradualist approach and be more reluctant to upset precedent and settled doctrines. Consequently, a Supreme Court composed of conservative justices can behave in an unpredictable, downright hostile, manner toward legislatures, rather than the more deferential style of judicial restraint that sometimes is associated with conservatives. Stanford Dean Kathleen Sullivan has identified no fewer than nine different conservative preferences that can pull a conservative interpreter in different directions depending on the constitutional issue to be decided in the case: (1) originalism; (2) textualism; (3) judicial restraint and deference to legislatures; (4) libertarianism and deregulation; (5) states' rights and decentralization; (6) traditionalism; (7) precedent; (8) free market capitalism; and (9) law and order. ${ }^{306}$ The preferences on this list are amorphous influences, however, and the list has a limited explanatory power in the abstract. It depends on the individual interpreter and the mix of preferences and their intensity. For example, some conservative judges might approach tradition proactively to help shape its evolution, claiming

${ }^{303}$ Randy E. Barnett, A Law Professor's Guide to Natural Law and Natural Rights, 20 HARV. J.L. \& PUB. POL'Y 655 (1997). See also Randy E. BARNETT, The STRUCTURE OF LIBERTY: JUSTICE AND THE RULE OF LAW (1998).

${ }^{304}$ See generally John S. Baker, Jr., Natural Law and Justice Thomas, 12 REgENT U. L. REV. 471 (1999-2000); Randy E. Barnett, The Intersection of Natural Rights and Positive Constitutional Law, 25 CONN. L. REv. 853 (1993); Thomas B. McAffee, Substance Above All: The Utopian Vision of Modern Natural Law Constitutionalists, 4 S. CAL. INTERDISC. L.J. 501 (1995); Anthony J. Sebok, The Insatiable Constitution, 70 S. CAL. L. REv. 417 (1997); Frederick Schauer, Constitutional Positivism, 25 ConN. L. REv. 797 (1993); R. George Wright, Is Natural Law Theory of Any Use in Constitutional Interpretation?, 4 S. CAL. INTERDISC. L.J. 463 (1995); Symposium, Natural Law v. Natural Rights: What Are They? How Do They Differ?, 20 HARV. J.L. \& PUB. POL'Y 627 (1997).

${ }^{305}$ Michael Stokes Paulsen, The Many Faces of "Judicial Restraint," 1993 PUB. INT. L. REV. 3.

${ }^{306}$ Kathleen M. Sullivan, The Jurisprudence of the Rehnquist Court, 22 NOvA L. REv. 743 (1998). 
that role for the courts. Other conservative judges might eschew any such judicial role and insist that the traditions already enshrined in the Constitution trump newer, lesser traditions. The "Straussians" - who are cultist followers of political philosopher Leo Strauss - advance their own unique version of originalism that expects judges to decide cases according to the political theory that the founders actualized in the Constitution, not just because it was the founders' theory, but because it is fundamentally the best possible theory of government - better than any theory before or since..$^{307}$

Conservatism is a big tent that covers many devotees of law and economics, public choice theory, and libertarianism. As the term itself suggests, law and economics uses economic principles to analyze legal questions. ${ }^{308}$ Public choice theory is more specific, applying principles of microeconomics to describe or predict the actual behavior of government actors, including legislators and judges. ${ }^{309}$ Libertarianism takes different forms with a common underlying philosophy that everyone should be allowed to be autonomous and free to do as they please so long as they do not infringe on the equal freedom of other individuals. ${ }^{310}$ It can get noisy inside, too, when some conservatives clamor for proactive judicial review to protect property rights, under the Takings Clause for example, and other conservatives resist by decrying such "judicial activism." 311 This contemporary argument echoes the debate over Lochner v. New York ${ }^{312}$ and substantive due process.

Conservatives reject the liberal motto that the Constitution has to be "kept in tune with the times," and that the courts should lead the way. Conservatives might

307 See generally Confronting THE CONSTITUTION: THE Challenge to Locke, MONTESQUIEU, JEFFERSON, AND THE FEDERALISTS FROM UTILITARIANISM, HISTORICISM, MARXISM, FREUdIANISM, PRAGMATISM, EXISTENTIALISM . . . (Allan Bloom ed., 1990).

308 See generally RICHARD POSNER, THE ECONOMICS OF JUSTICE (1983); Gerald N. Rosenberg, The Implementation of Constitutional Rights: Insights from Law and Economics, 64 U. CHI. L. REV. 1215 (1997).

309 See generally RoBert D. COOTER, THE STRATEgIC CONSTITUTION (2000); Daniel A. Farber \& Philip P. Frickey, The Jurisprudence of Public Choice, 65 TEX. L. REV. 873 (1987); Symposium on the Theory of Public Choice, 74 VA. L. REV. 167 (1988).

310 See generally RoBERT NOZICK, ANARCHY, STATE, AND UTOPIA (1974); David Bergland, Libertarianism, Natural Rights and the Constitution: A Commentary on Recent Libertarian Literature, 44 CLEV. ST. L. REV. 499 (1996); James E. Fleming, The Parsimony of Libertarianism, 17 ConST. CoMmENT. 171 (2000); Louis Michael Seidman, Public Principle and Private Choice: The Uneasy Case for a Boundary Maintenance Theory of Constitutional Law, 96 YALE L.J. 1006 (1987).

311 See generally ECONOMIC LIBERTIES AND THE JudiCIARY (James A. Dorn \& Henry G. Manne eds., 1987); Richard EPSTEIN, TAKINGs: Private Property AND THE Power OF EMINENT DOMAIN (1985); Richard A. Epstein, History Lean: The Reconciliation of Private Property and Representative Government, 95 COLUM. L. REV. 591 (1995); Richard E. Levy, Escaping Lochner's Shadow: Toward a Coherent Jurisprudence of Economic Rights, 73 N.C. L. REV. 329 (1995).

312198 U.S. 45 (1905). See generally BAKER \& WILLIAMS, supra note *, at 389-94. 
turn that cliché around to insist that judges are supposed to keep the times in tune with the Constitution - "to the extent possible."313

\section{FEMINIST THEORY}

Although generalizations are somewhat problematic, the overall priority of feminist theory is to incorporate and integrate women's perspectives into the legal system. ${ }^{314}$ It is a perspective, however, that basically is critical of the law for being a patriarchal institution. University of Missouri-Kansas City professor Nancy Levit has identified and described four different schools of feminist theory. ${ }^{315}$ "Liberal feminists" argue for the elimination of all gender-based classifications. ${ }^{316}$ Men are viewed as the legal reference or analytical norm to argue for equality and against sexual stereotypes that limit opportunities for both women and men. "Cultural feminists" emphasize an innate difference between women and men - men are the "other." ${ }^{\text {117 }}$ Formal equality is not desirable; rather the essential biological and social facts that women bear children and are primarily responsible for child-rearing oblige the legal system to accommodate these differences. ${ }^{318}$ Some "difference feminists" believe that ultimately, men cannot be reconciled with feminism, and therefore they pursue a separatist agenda to privilege feminist ethics as being morally superior. ${ }^{319}$ "Radical feminists" view men as oppressors and emphasize the subordination of

Conservatives concede, as they must, that necessity is the mother of invention; where they differ from mainstream liberals, to cite still another aphorism, is in their refusal to make a virtue of necessity. They cannot say, because it would be foolish to say, that the times must be kept in tune with the Constitution; but because our freedom and prosperity depend upon it, they do say, and say emphatically, that the times, to the extent possible, should be kept in tune with the Constitution.

Walter Berns, Conservativism, in 2 ENCYCLOPEDIA, supra note 8, at 507, 510 . See also supra text accompanying notes $220-22$.

314 "Feminist theory encompasses such a large and diverse body of work that it can no longer be described succinctly." Christine A. Littleton, Feminist Theory, in 3 ENCYCLOPEDIA, supra note 8, at 1032.

315 NANCY LeVit, The Gender LiNE: Men, Women, ANd THE LAW 189-95 (1998).

316 Id. See generally David Cole, Strategies of Difference: Litigating for Women's Rights in a Man's World, 2 LAW \& INEQ. 33 (1984).

${ }^{317}$ LEVIT, supra note 315, at 189-95. See generally Robin West, Jurisprudence and Gender, 55 U. CHI. L. REv. 1 (1988).

${ }^{318}$ LEVIT, supra note 315, at 189-95. See generally Wendy W. Williams, Equality's Riddle: Pregnancy and the Equal Treatment/Special Treatment Debate, 13 N.Y.U. REV. L. \& SOC. CHANGE 325 (1984-85).

${ }^{319}$ LEVIT, supra note 315, at 189-95. See generally Christine Littleton, Feminist Jurisprudence:The Difference Method Makes, 41 STAN.L.REV.751 (1989)(reviewing CATHERINE A. MACKINNON, FEMINISM UNMODIFIED (1987)). 
women by male norms in law and society. ${ }^{320}$ They seek to address class-based oppression by reforming social institutions. They are not satisfied with achieving equality, but rather they conceive of gender politics as a zero-sum game in which women must affirmatively take power away from their exploiters. These different schools of feminism are related and overlap; however, these writings are philosophically deeper and conceptually more nuanced than this simple summary can describe. ${ }^{321}$ And, of course, individual thinkers move freely among them intellectually.

Of course, many constitutional law issues relate to gender and sex. ${ }^{322}$ Extrapolating from the work of social scientist and cultural feminist Carol Gilligan, ${ }^{323}$ Vanderbilt's Suzanna Sherry has argued that the Constitution as interpreted in the general liberal tradition has a quintessentially masculine nature, but she believes that she sees a feminine perspective - though not necessarily a feminist perspective in Justice O'Connor's jurisprudence. ${ }^{324}$ However, Justice O'Connor disputes this characterization of her jurisprudence. ${ }^{325}$

Feminist high theorizing thus has moved from a liberal-equality stage to a cultural-difference stage to a radical-dominance stage and to a postmodern-antiessentialist stage that is skeptical of all social constructs of "truth" and that seeks to

320 LEVIT, supra note 315, at 189-95. See generally ANDREA DWORKIN \& CATHERINE A. MACKINNON, PORNOGRAPHY AND CIVIL RIGHTS: A NEW DAY FOR WOMEN's EQUALTTY (1988).

321 Various jurisprudes have attempted to identify and group feminist writings into separate and distinct schools of thought. For example, Professor Sinha describes no fewer than seven schools of feminist theory: (1) "liberal, or equal opportunity, or formal equality, or symmetricist feminism;" (2) "assimilationist feminism;" (3) "bivalent, or difference, or special treatment feminism;" (4) "incorporationist feminism;" (5) "different-voice, or cultural, or relational feminism;" (6) "dominance, or radical feminism;" and (7) "post-modern feminism." SINHA, supra note 280, at 325-41. See also FEMINIST LEGAL THEORY: FOUNDATIONS (D. Kelly Weisberg ed., 1993); FEMINIST LEGAL THEORY: READING IN LAW AND GENDER (Katharine T. Bartlett \& Rosanne Kennedy eds., 1991); RoBIN WEST, CARING FOR JUSTICE (1997); Feminist Jurisprudence Symposium, 24 GA. L. REV. 759 (1990); Martha Minow, Feminist Reason: Getting It and Losing It, 38 J. LeGAL EdUC. 47 (1989); Ann C. Scales, Towards a Feminist Jurisprudence, 56 IND. L.J. 375 (1981); Joan C. Williams, Deconstructing Gender, 87 MICH. L. REV. 797 (1989).

322 See generally CATHERINE A. MACKInNON, TOWARd A FEMINIST THEORY OF THE State (1989); Tracy E. Higgins, Democracy and Feminism, 110 HaRV. L. ReV. 1657 (1997); Kenneth L. Karst, Woman's Constitution, 1984 DUKE L.J. 447; Sylvia A. Law, Rethinking Sex and the Constitution, 132 U. PA. L. REV. 955 (1984).

323 Carol Gilligan, In a DifFerent Voice: PSychological TheORY AND WoMen's DEVELOPMENT (1982).

324 Suzanna Sherry, Civic Virtue and the Feminine Voice in Constitutional Adjudication, 72 VA. L. REV. 543 (1986). See also Symposium, Celebration of the Tenth Anniversary of Justice Ruth Bader Ginsburg's Appointment to the Supreme Court of the United States, 104 ColuM. L. REv. 1 (2004).

${ }^{325}$ Sandra Day O'Connor, Portia's Progress, 66 N.Y.U. L. REV. 1546, 1553 (1991). 
be inclusive and other-regarding of the diversity of women of color and lesbians in such a way that they are respected and empowered. ${ }^{326}$ Martha Chamallas, at the University of Pittsburgh, has described these intellectual developments and chronicled the internal and external debates over feminist theory as well as the diversity of views within feminist thought. ${ }^{327}$

\section{CRITICAL RACE THEORY}

As the term suggests, critical race theory focuses on how race and ethnicity operate in the legal system in favor of white-dominated institutions and against out-groups. ${ }^{328}$ It is an effort to confront overt and covert racial domination. A manifesto against traditional constitutional theory provides these defining attitudes: belief that racism is endemic in society; skepticism towards all claims of neutrality and objectivity; contextual and historical analysis of law; recognition for the experiential knowledge of persons of color; eclecticism and interdisciplinary methodology; and a commitment towards the elimination of racial and all other forms of oppression. ${ }^{329}$ Critical race theory is hyper-critical of constitutional law and Supreme Court decisions and doctrines relating to race. ${ }^{330}$ In the foreword to a foundational collection of critical race theory scholarship compiled by professors at UCLA, Western State, Georgetown, and Columbia, respectively, the editors advocate an oppositional vision of racial justice that rejects the views of race in liberalism and conservatism and fundamentally calls into question the legitimacy of the Supreme Court as an institution that preserves the white racial hegemony over society and protects conscious and unconscious racism. ${ }^{331}$ For these thinkers, race is nothing more and nothing less than a social construct invented and perpetuated by the racial majority to subjugate the racial minority. ${ }^{332}$ Law is the principal means for constructing race and for abusing people of color - and this pattern of abuse characterizes the Supreme Court's racial

326 See generally FEMINIST LEGAL THEORY: AN ANTI-ESSENTIALIST READER (Nancy E. Dowd \& Michelle S. Jacobs eds., 2003); Deborah Rhode, Feminist Critical Theories, 42 STAN.L.REV. 617 (1990); Frances Olsen, Feminism and Critical Legal Theory: An American Perspective, 18 INT'L J. SOC. L. 199 (1990).

327 Martha Chamallas, INTROduction to Feminist Legal TheORY (1999).

328 Kimberlé Crenshaw et al., Critical Race Theory, in 2 ENCYCLOPEDIA, supra note 8, at 726.

329 Mari J. Matsuda et al., Words that Wound: Critical Race Theory, ASSAULTIVE SPEECH, AND THE FIRST AMENDMENT 6-7 (1993). See also Critical RACE TheORY: THE CuTTING EdGE (Richard Delgado \& Jean Stefancic eds., 2d ed. 2000).

${ }^{330}$ See generally Girardeau A. Spann, Pure Politics, 88 MiCH. L. REV. 1971 (1990).

331 CRITICAL Race TheORY: The Key WrITINGS That Formed THE MOVEMENT xi-xxxii (Kimberlé Crenshaw et al. eds., 1995).

${ }^{332}$ See generally Ian F. Haney López, The Social Construction of Race: Some Observations on Illusion, Fabrication, and Choice, 29 HARV. C.R.-C.L. L. REV. 1 (1994). 
doctrines. ${ }^{333}$ Of course, this raises a postmodern dilemma: if race is merely a social construct, then what critical race theorists claim about racism must also be a social construct. But then the postmodern way to walk out of the corner over the wet paint is to insist that race is both socially constructed and real. ${ }^{334}$ "Whiteness" too is a social construct but it is afforded legal privilege and social status. ${ }^{335}$ Critical Race Theorists practice "identity politics" to focus on group membership and group rights, but they favor a multiculturalism in which diversity is celebrated and not denied, ignored, or assimilated. ${ }^{336}$

Charles Lawrence, of Georgetown, likens racism to a disease that cannot be cured with legal doctrine, at least not the legal doctrines of contemporary Supreme Court Justices. ${ }^{337}$ The narrative form of the genre of critical race theory scholarship may be sampled by reading the book-length diary of Columbia Law Professor Patricia J. Williams, ${ }^{338}$ or a series of short stories by Boston College's Anthony Farley ${ }^{339}$ - who also has provocatively written that race relations between blacks and whites in the United States may be likened to the sexual pathology of sadomasochism. ${ }^{340}$ Finally, at least for present purposes, Derrick Bell, now at New York University, and one of the founders of Critical Race Theory, is so pessimistic about the future of race relations in America that he predicts that persons of color are prepared to continue their fight for equality, without any real hope or a realistic likelihood of succeeding, merely as a means to preserve their own sense of individual dignity from engaging in the struggle. ${ }^{341}$ To say that these Critical Race Theory scholars engender controversy and provoke other more traditional constitutional scholars would be something of an understatement. ${ }^{342}$

${ }^{333}$ See generally Neil Gotanda, A Critique of "Our Constitution is Color-Blind," 44 STAN. L. Rev. 1 (1991).

${ }_{334}$ See generally Kimberlé Crenshaw, Mapping the Margins: Intersectionality, Identity Politics, and Violence Against Women of Color, 43 STAN. L. REv. 1241 (1991).

335 See generally IAN F. HANEY LOPEZ, WHITE By LAW: THE LEGAL CONSTRUCTION OF RACE (1996); Cheryl I. Harris, Whiteness as Property, 106 HARV. L. REv. 1707 (1993); john a. powell, The "Racing" of American Society: Race Functioning as a Verb before Signifying as a Noun, 15 LAW \& INEQ. 99 (1997).

${ }^{336}$ See generally John O. Calmore, Random Notes of an Integration Warrior, 81 MINN.

L. REv. 1441 (1997); Gary Peller, Race Consciousness, 1990 DUKE L.J. 758.

${ }^{337}$ Charles R. Lawrence III, The Epidemiology of Color-Blindness: Leaming to Think and Talk About Race, Again, 15 B.C. THIRD WORLDL.J. 1 (1995); Charles R. Lawrence III, Race, Multiculturalism, and the Jurisprudence of Transformation, 47 STAN. L. REV. 819 (1995).

338 PatriCia J. Williams, The AlChEMy Of RACE AND Rights (1991). See also DeRRICK Bell, AND We ARE Not SAVED: The Elusive Quest For RACIAL Justice (1987); RichaRd DElgado, The Rodrigo Chronicles: Conversations About AMERICA AND RaCE (1995).

339 Anthony Paul Farley, Thirteen Stories, 15 TOURO L. REV. 543 (1999).

${ }^{340}$ Anthony Paul Farley, The Black Body as Fetish Object, 76 OR. L. REV. 457 (1997).

341 DeRrick Bell, Faces at THE BotTom of THE Well: THE PERMANENCE OF RACISM (1992).

${ }^{342}$ See generally Daniel A. Farber \& SuZANna SHeRry, Beyond All Reason: THE 


\section{POSTMODERN THEORY}

Postmodernism is an anti-theory theory characterized by an intellectual playfulness and a dressed-all-in-black sense of irony that makes it difficult to decide if the theory is brilliant, absurd, or both. ${ }^{343}$ Dennis Arrow demonstrated his in his rich satire piece on postmodern constitutionalism that went on and on for about 230 pages of "pomobabble." 344 Nonetheless, there are many devout believers, like Ronald Krotoszynski from Washington and Lee University, who take up the law review cudgels to defend legal postmodernism as being both compelling and inevitable. ${ }^{345}$

Postmodernism calls into question the whole enterprise of "hermeneutics," i.e., the study of the methods of interpretation that give meaning to texts. ${ }^{346}$ Postmodernism questions the meaning of meaning. It denies reason to insist that belief systems about reality are merely social constructs, thus denying everything from science to politics. A postmodernist would admit that science and politics have great utility, however, so the theory is somewhat circular. There are no foundational principles. There is no such thing as knowledge. There is no such thing as truth except for the "truth" that there is no truth. Postmodernists thus reject the Enlightenment beliefs in knowledge, truth, reason, and free will. Of course, they admit that Enlightenment thinkers themselves actually did believe in those things. Epistemology is the branch of philosophy that studies the nature of knowledge, its presuppositions and foundations, as well as its extent and validity. Postmodern philosophy is subversive of the authority of philosophy by rejecting anything and everything foundational.

Peter Schanck of Marquette University admits that most people, and even many academics, find these ideas "inconceivable, ridiculous, or abhorrent" but he makes the case that postmodernism has become one of the dominant theories in the legal academy. ${ }^{347}$ Stephen Feldman argues this has implications for the Supreme Court which, like it or not, functions in a postmodern world and sometimes operates in a

Radical AsSault ON TRUTH IN AMERICAN LAW (1997); Randall L. Kennedy, Racial Critiques of Legal Academia, 102 HARV. L. REV. 1745 (1989); Mark Tushnet, The Degradation of Constitutional Discourse, 81 GEO. L.J. 251 (1992).

${ }^{343}$ Pierre Schlag, Postmodernism and Constitutional Interpretation, in 4 ENCYCLOPEDIA, supra note 8, at 1971.

${ }^{344}$ Dennis W. Arrow, Pomobabble: Postmodern Newspeak and Constitutional "Meaning" for the Uninitiated, 96 MiCH. L. REV. 461 (1997).

345 Ronald J. Krotoszynski, Jr., Legal Scholarship at the Crossroads: On Farce, Tragedy, and Redemption, 77 TEX. L. REV. 321 (1998).

346 "[T] $]$ here is really no identifiable hermeneutic party in current constitutional law and theory." John T. Valauri, Interpretation, Critique, and Adjudication: The Search for Constitutional Hermeneutics, 76 CHI.-KENT L. REV. 1083, 1086 (2000). See also Frederick Mark Gedicks, Conservatives, Liberals, Romantics: The Persistent Quest for Certainty in Constitutional Interpretation, 50 VAND. L. REV. 613 (1997).

347 Peter C. Schanck, Understanding Postmodern Thought and Its Implications for Statutory Interpretation, 65 S. CAL. L. REV. 2505, 2512 (1992). 
postmodern manner. ${ }^{348}$ For Yale's Jack Balkin, the constitutional question that remains to be answered in the postmodern era is how have changes in society changes in technology, communications, lifestyles, and work ways - changed people's understandings about the Constitution, individual rights, and government power? ${ }^{349}$

Postmodernism undermines the traditional understanding of constitutional interpretation by insisting that meaning is not contained in the document, but only in the interpreter. Before he became Chief Justice, Charles Evans Hughes is often quoted to have observed, "[w]e are under a Constitution but the Constitution is what the judges say it is." ${ }^{350}$ Nonetheless, Yale's Owen Fiss still maintains that something resembling objectivity remains because Supreme Court Justices are members of an interpretative community and they accept its disciplining rules to restrain their thinking and decision making. ${ }^{351}$ Thus, within the interpretative community of constitutionalists, what judges do to interpret the Constitution is real enough and not subject to their absolute personal whim or caprice. For example, a judge who says that Congress cannot regulate interstate commerce either is a member of that interpretative community who for some reason is badly mistaken and is in dire need of remedial education, or is not a member of that interpretative community and someone who can be ignored altogether. Sanford Levinson of the University of Texas, who is one of the leading contemporary constitutionalists, ${ }^{352}$ doubts if an interpretative community really does exist for the Constitution, however, given the variety of interpretative methodologies that exist today. ${ }^{353}$ Furthermore, the everyday occurrence is that the nine Justices cannot agree on either a general interpretative method or a particular interpretation in a given case. Premier postmodernist Stanley Fish, formerly of the Duke Law School faculty, insists that the Justices are not constrained by theory or by external rules, but they behave the way they do because they are personally situated so deeply in the context of law and judging. ${ }^{354}$ Interpretation is authority and authority is interpretation. The Constitution does not

348 Stephen M. Feldman, The Supreme Court in a Postmodern World: A Flying Elephant, 84 MINN. L. REV. 673 (2000).

349 J.M. Balkin, What Is a Postmodern Constitutionalism?, 90 MICH. L. REV. 1966 (1992). See also J.M. Balkin, Deconstructive Practice and Legal Theory, 96 YALE L.J. 743 (1987); Robert Justin Lipkin, Can American Constitutional Law Be Postmodern?, 42 BUFF. L. REV. 317 (1994).

350 The complete quotation provides a different reading: "We are under a Constitution, but the Constitution is what the judges say it is, and the judiciary is the safeguard of our liberty and property under the Constitution." Charles E. Hughes, Speech to the Elmira, New York, Chamber of Commerce, May 3, 1907, in MERLO J. PUSEY, ChARLES EVANS Hughes 1, 204 (1951).

351 Owen M. Fiss, Objectivity and Interpretation, 34 STAN. L. REV. 739 (1982).

352 See generally Legal Scholarship Symposium: The Scholarship of Sanford Levinson, 38 Tulsa L. ReV. 553 (2003).

353 Sanford Levinson, Law as Literature, 60 TEX. L. REv. 373 (1982).

354 Stanley Fish, Fish v. Fiss, 36 STAN. L. REV. 1325 (1984). 
have one meaning or many meanings. Meaning is conferred on the Constitution only by interpretation. The final examination of a postmodern con law prof would ask: "Would it be more of an act of nihilism to conclude that the Constitution means everything or to conclude that it means nothing?" The model answer would read: "There is no right answer because that is the wrong question." 355 Enough.

\section{DOES THEORY MATTER?}

Honk if you think constitutional theory is a lot of footnoted bullshit. ${ }^{356}$

Minnesota's Daniel Farber and Vanderbilt's Suzanna Sherry have written a book that says that just about all the other con law profs and theoretical types mentioned in this Article are full of it. ${ }^{357}$ They insist that constitutional law ain't rocket science: grand unified theories ought to be saved for explaining the origin of the universe. ${ }^{358}$ Farber and Sherry prefer the way Supreme Court Justices actually seem to behave in real life to decide cases pragmatically and to write undertheorized opinions about the Constitution. They seriously doubt that the highfalutin stuff in the fancy law reviews is really any better for reaching sound decisions and controlling judicial discretion. They argue that no single foundational idea can account for all of American constitutional history. They and some other constitutionalists have argued that the entire enterprise of constitutional theorizing might be furthered by paying more attention to how the Constitution actually gets implemented by the institutions of government than by imagining any more new-andimproved interpretative philosophies.

If you are wondering to yourself whether all this theorizing is merely academic, in one sense you are correct: law professors take constitutional theory far more seriously than do judges. ${ }^{359}$ Richard Posner, who is a federal judge on the Seventh

Now I know that this will seem immediately paradoxical. How can there be at once no texts that have a single meaning and no texts that have many meanings, and how can this impossible state of affairs (even if it could exist) be seen as a solution to the problem of interpretation?

Id. at 1334 .

356 "Honk if you are tired of constitutional theory." Brown, supra note 133, at 531. Sanford Levinson, Constitutional Theory (Update), in 2 ENCYCLOPEDIA, supra note 8, at 657; Mark Tushnet, Constitutional Theory, in 2 ENCYCLOPEDIA, supra note 8, at 654.

357 Daniel A. Farber \& Suzanna SherRy, Desperately Seeking CerTaINTY: THE MisGUiDED QUEST FOR CONSTITUTIONAL FOUNDATIONS (2002).

358 See Erwin Chemerinsky, A Grand Theory of Constitutional Law?, 100 MICH. L. REV. 1249 (2002) (reviewing JED RUBENFELD, FREEDOM AND TIME: A THEORY OF CONStitutional Self-Government (2001)). Will there ever be a Nobel Prize awarded in constitutional theory? See Thomas S. Ulen, A Nobel Prize in Legal Science: Theory, Empirical Work, and the Scientific Method in the Study of Law, 2002 U. ILL. L. REV. 875.

359 For example, the First Annual Constitutional Theory Conference was held in 2003. First Annual Constitutional Theory Conference, at http://law.vanderbilt.edu/about/news/ 2003/04_11.html (last visited Nov. 12, 2004). See also Legal Theory Blog, at http://lsolum. 
Circuit and a law professor at the University of Chicago, argues against the entire enterprise of constitutional theory, and he is especially dismissive of what he calls "academic moralism" that lacks both intellectual cogency and emotional persuasiveness. ${ }^{360}$ Posner could have judges the fact that constitutional law is lacking in premises from which judges of different political views can reason to conclusions on which they can agree. ${ }^{361}$ Justice Breyer, whose opinion counts even more, recently explained that all he can do is look for a pragmatic resolution of each case that will best serve the underlying purpose of the constitutional provision consistent with a common sense respect for democratic self-government. ${ }^{362}$

Some anti-theory theorists have posited a more general theory of government in which judicial review is situated. Yale's Jed Rubenfeld is one con law prof who is impatient with all the academic theorizing. ${ }^{363}$ Rubenfeld reconceptualizes constitutionalism as a manifestation of democracy. He argues that none of the prevailing constitutional theories manages to distinguish between interpreting and rewriting the Constitution and, at the same time, to account for the undeniable influence of evolving normative values that go beyond the text and are contrary to original understandings. He insists that theory has asked the wrong question and that the right question is, why should the Constitution have any legitimacy over time, i.e., why should we even try to interpret and obey it, in the first place? Christopher $L$. Eisgruber of Princeton University has written a comparably ground-breaking book that also sets out to rethink constitutional theory in favor of constructing a theory of democracy that includes non-majoritarian constitutionalism. ${ }^{364}$ The elected political branches are incomplete in themselves. ${ }^{365}$ The Supreme Court is democratic in a different, complimentary way. ${ }^{366}$ It is an important institution that represents the people on questions of political and moral principles as it goes about dispensing a higher justice. ${ }^{367}$ Both of these books self-consciously turn away from standard constitutional theory to pursue what might be called political philosophy more directly. ${ }^{368}$ It turns out, according to this approach, that the Justices have been

blogspot.com (last visited Nov. 9, 2004); Political Theory Daily Review, at http://political theory.info (last visited Nov. 19, 2004).

${ }^{360}$ Richard A. Posner, Against Constitutional Theory, 73 N.Y.U. L. REV. 1 (1998); Richard A. Posner, The Problematics of Moral and Legal Theory, 111 HARV. L. REV. 1637, 1639-40 (1998).

361 See generally Ira C. Rothgerber, Jr., Conference on Constitutional Law: Constitutional Theory and the Practice of Judging, 63 U. COL. L. REV. 291 (1992); Symposium on the Renaissance of Pragmatism in American Legal Thought, 63 S. CAL. L. REV. 1569 (1990).

${ }^{362}$ Stephen Breyer, Our Democratic Constitution, 77 N.Y.U. L. REV. 245 (2002).

363 Jed Rubenfeld, Freedom and Time: A Theory of Constitutional SelfGOVERNMENT (2001).

364 Christopher L. EISGRUBER, CONSTITUTIONAL SELF-GOVERNMENT (2001).

${ }^{365}$ Id. at 7-9.

366 Id.

367 Id.

368 See generally James E. Flemming, Constructing the Substantive Constitution, 72 TEX. 
behaving like so many Wizards of $\mathrm{Oz}$, writing opinions that tell us to ignore the man standing behind the curtain - and all this time it has been just that puny little man - or more precisely nine mortal, fallible people dressed in robes. Perhaps we should be reminded here of what Alexander Bickel, the Yale professor, once wrote to an earlier generation of academic skeptics who claimed they could see through everything: "And yet we do need, individually and as a society, some values, some belief in the foundations of our conduct, in order to make life bearable. If these too are lies, they are . . . true lies; if illusions, then indispensable ones. To abandon them is to commit moral suicide." 369

Constitutional theory should be appreciated only as a means to an end, and not an end in and of itself. Constitutional theory helps jurists, scholars, and students to assign meaning to the past, and it shapes arguments over the future of constitutional law. One must recognize the limitations of theory, however. Certainly, there is not much to be gained from attempts to explain that part of constitutional law that merely reflects the individual Justice's political views. But theory helps us to see consistencies in analysis, regularities in holdings, commonalities among Justices, and agreements across ideological divides. Thus, theory is a valuable and helpful context - a way of collecting and organizing and making sense of the output of the Supreme Court. Legal theory and constitutional theory certainly matter to law professors, as is evidenced by the enormous output of tracts from the tenure track. ${ }^{370}$ All the leading law reviews regularly publish symposia on constitutional theory. There are books and articles too numerous to mention about constitutional theory and its discontents. Certainly, theory has its critics, like Georgetown professors Louis Seidman and Mark Tushnet, who conclude that constitutional argument has devolved into merely argument for argument's sake, that modern constitutional theory has failed its essential purpose to bridge the differences between opposing factions by appealing to their common values and principles. ${ }^{371}$ Indeed, the latest headline is that theory has been declared dead from an apparent suicide. ${ }^{372}$

L. REV. 211 (1993); Symposium: Theories of Constitutional Self-Government, 71 FORDHAM

L. REV. 1721 (2003).

369 AleXANDER M. BiCKEl, The MORALITY OF CONSENT 77 (1975). See also Elizabeth S. Anderson \& Richard H. Pildes, The Expressive Theories of Law: A General Restatement, 148 U. PA. L. REV. 1503 (2000) (providing a general discussion of expressive theories and the expressive character of constitutional law).

370 That much written output must have some human intelligence and insight behind it. See Jill Lawless, Typing Monkeys Don't Write Shakespeare, WaSh. POST, May 9, 2003.

371 LOUIS MICHAEL SEDMAN \& MARK V. TUSHNET, REMNANTS OF BELIEF: TEMPORARY CONSTITUTIONAL ISSUES 23-25 (1996).

${ }^{372}$ Emily Eakin, The Latest Theory Is That Theory Doesn't Matter, N.Y. TIMES, Apr. 19, 2003, at D9. (At a recent symposium on the future of theory Stanley Fish said, inter alia, "I wish to deny the effectiveness of intellectual work. And especially, I always wish to counsel people against the decision to go into the academy because they hope to be effective beyond it."). See also Lawrence Lessig, The Puzzling Persistence of Bellbottom Theory: What a Constitutional Theory Should Be, 85 GEO. L.J. 1837 (1997). 
To "psych out" your con law prof, you might read some of his or her articles on the subject. ${ }^{373}$ You are part of the intended readership, although other professors are the primary audience. To understand an individual Justice's interpretative philosophy, pay attention to the "interpretative moves" the Justice makes. ${ }^{374}$ Look for the Justice's solitary opinions, separate concurring opinions or dissenting opinions, to read a purer, unadulterated version of the Justice, and also pay special attention to those occasions when a Justice says "if I were in the legislature, I would vote the other way, but because I am a judge I vote the way I do because of the Constitution." ${ }^{375}$ Those are the clearest examples of a Justice following an interpretative theory beyond the first-year student's common cynicism that judges really only decide which result they like and make up a phony rationale after the fact. ${ }^{376}$ To master constitutional law for the final exam and the bar examination, you have to behave as if it is law. If you have a theoretical bent and want to look for a constitutional theory on your own, Richard Fallon of Harvard offers you some selection tips on how to choose a theory. ${ }^{377}$ But be reminded that an effective constitutional theory should impose genuine constraints on its adherents. Constitutional theory is both descriptive and prescriptive. Theory should matter. ${ }^{378}$ By the time you finish the course on constitutional law, you should know enough about the subject to be able to evaluate the claims made on behalf of the various theories.

Whether theory does matter - whether theory does distinguish constitutional law from politics - still remains the central question. ${ }^{379}$ Should unelected and lifetenured judges behave differently from elected officials? Is the Constitution merely a litmus of politics, in a dispute like the 2000 Election Case, which turns red for Republicans and blue for Democrats? ${ }^{380}$ Is what $\mathrm{Al} \mathrm{Smith} \mathrm{said} \mathrm{about} \mathrm{politics} \mathrm{also}$

373 An author search, for example AU("thomas e. baker") in the JLR database on Westlaw, will generate a reading list for your professor.

374 See generally Bernard Schwartz, "Brennan vs. Rehnquist"-Mirror Images in Constitutional Construction, 19 OKL. CrTY U. L. REV. 213 (1994).

375 E.g., Lawrence v. Texas, 539 U.S. 558, 605-06 (2003) (Thomas, J., dissenting); Furman v. Georgia, 408 U.S. 238, 405-07 (1972) (Blackmun, J., dissenting).

376 Professor Tushnet offers this alternative test: "A constitutional theory fails to constrain judges - fails, that is, to reduce the risk of judicial tyranny sufficiently — if it licenses judges to require in their sole discretion either that a strict regime of laissez faire be followed without deviation or that socialism be adopted." Tushnet, supra note 65 , at 684 . His most recent work describes a new constitutional order. See MARK V. TUSHNET, A NEW CONSTITUTIONAL ORDER (2003).

377 Richard H. Fallon, Jr., How to Choose a Constitutional Theory, 87 CAL. L. REV. 535 (1999).

${ }^{378}$ See Gerard J. Clark, An Introduction to Constitutional Interpretation, 34 SUFFOLK U. L. REV. 485 (2001).

379 See generally Mark A. Graber, Constitutional Politics and Constitutional Theory: A Misunderstood and Neglected Relationship, 27 L. \& SOC. INQUIRY 309 (2002) (reviewing LuCas A. POWE, The Warren COURT AND AMERICAN POLITICS (2000)).

380 See Bush v. Gore, 531 U.S. 98 (2000). “'Honk if you've heard enough about Bush v. 
true about constitutional law - "it all depends whose ox is being gored." current wisdom in political science is that a Justice's individual policy preferences determine his or her judicial decision-making. ${ }^{382}$ Thus, constitutional law is politics to a political scientist. They have the stats and charts to prove it. ${ }^{383}$

As we have seen, constitutional theory does not inevitably lead to only conservative or liberal outcomes - there are both kinds of theories and some theories explicitly purport to be apolitical. During the House impeachment and the Senate trial of President Clinton in 1998, for example, those on both sides of the aisle accused the other side of constitutional hypocrisy and flip-flopping their constitutional arguments. ${ }^{384}$ Admittedly, constitutional theory does not seem to lead to certain answers to constitutional questions as much as it seems to provide competing arguments for going about deciding them. The ultimate usefulness of any constitutional theory, however, is to help differentiate between good arguments and bad arguments and to make it at least somewhat more likely that the interpreter

Gore!"' Laurence H. Tribe, eroG .v hsuB and Its Disguises: Freeing Bush v. Gore from Its Hall of Mirrors, 115 HARV. L. REV. 170, 172 (2001). See generally 36 DAYS: THECOMPLETE Chronicle OF THE 2000 PRESIDENTIAL Election Crisis (The New York Times ed., 2001); Bush v. Gore: The Court CASES AND the Commentary (E.J. Dionne, Jr. \& William Kristol eds., 2001); Richard A. POSNER, BREAKING THE DEADLOCK: THE 2000 ELECTION, THE CONSTITUTION, AND THE COURTS (2001); THE VOTE: BuSh, GORE \& THE SUPREME COURT (Cass R. Sunstein \& Richard A. Epstein eds., 2001); Forrest Maltzman et al., Supreme Court Justices Really Do Follow the Election Returns, 37 PSONLINE 839 (Oct. 2004), at http://www.apsanet.org/PS, available at http://www.henryfarrell.net/images/scj.pdf (last visited Nov. 22, 2004). Ronald J. Krotozynski, Jr., An Epitaphios for Neutral Principles in Constitutional Law: Bush v. Gore and the Emerging Jurisprudence of Oprah!, 90 GEO. L.J. 2087 (2002).

${ }^{381}$ Henry J. ABRaHAM, The Judicial Process: AN INTROductory ANALYSIS OF THE COURTS OF THE UNITED STATES, ENGLAND, AND FRANCE 312 (6th ed. 1993) (quoting Al Smith). There is a leitmotif of mistrust of the government that runs throughout American constitutional history. GARRY WILls, A NeCESSARY EvR: A History OF AMERICAN DISTRUST OF GOVERNMENT (1999).

382 See Lee EPSTEIN \& JaCK KNiGht, The Choices Justices MAKe (1998); JefFrey A. Segal \& Harold J. SPaEth, The Supreme Court and the AtTitudinal Model REVISITED (2002).

${ }^{383}$ See, e.g., Robert A. Dahl, Decision-Making in a Democracy: The Role of the Supreme Court as a National Policy-maker, 6 J. PUB. L. 279 (1957); Lee Epstein et al., The Supreme Court as a Strategic National Policymaker, 50 EMORY L.J. 583 (2001); Scott D. Gerber \& Keeok Park, The Quixotic Search for Consensus on the U.S. Supreme Court: A CrossJudicial Empirical Analysis of the Rehnquist Court Justices, 91 AM. POL. SCI. REV. 390 (1997); Lawrence Sirovich, A Pattern Analysis of the Second Rehnquist U.S. Supreme Court, 100 PROCEEDINGS OF THE NATIONAL ACAdEMY OF SCIENCES OF THE UNITED STATES OF AMERICA at 7432-37 (June 24, 2003).

${ }^{384}$ Compare Neal Devins, Bearing False Witness: The Clinton Impeachment and the Future of Academic Freedom, 148 U. PA. L. REv. 165 (1999), with Cass R. Sunstein, Professors and Politics, 148 U. PA. L. REv. 191 (1999). 
will reach not just a good interpretation, but the best interpretation of the Constitution. The admission that there are some arguments that are bad arguments - and everyone would have to admit that there are plenty of wrong answers to constitutional questions - demonstrates the logical fallacy behind the novice's skepticism that in constitutional law anything goes. ${ }^{385}$

I will end this article about American constitutional theory - written for the reader who is beginning the modern curriculum of constitutional law - with some two-century old wisdom from the founding. In Federalist Paper No. 15, the pseudonymous Publius (Alexander Hamilton) offered this encouragement and advice to the someone setting out to understand the meaning and significance of the Constitution:

If the road over which you will still have to pass should in some places appear to you tedious or irksome, you will recollect that you are in quest of information on a subject the most momentous which can engage the attention of a free people, that the field through which you have to travel is in itself spacious, and that the difficulties of the journey have been unnecessarily increased by the mazes with which sophistry has beset the way. It will be my aim to remove the obstacles to your progress in as compendious a manner as it can be done, without sacrificing utility to dispatch. ${ }^{386}$

These are three questions all of us - as commentators, as judges, as citizens - should ask about every proposed constitutional reading. First, what we call the Preference Question: Setting aside one's attitude toward the result, is the proposed reading not merely $a$ plausible interpretation but the most plausible interpretation? Second, the Concreteness Question: Is the doctrine precise enough to separate what's permitted from what's forbidden? And third, the Unintended Consequences Question: Will the rationale for the doctrine, if accepted, sweep far more broadly than we might like?"

Alex Kozinski \& Eugene Volokh,APenumbra Too Far, 106HARv.L.REV. 1639, 1641 (1993).

386 The Federalist No. 15, at 105 (Alexander Hamilton) (Clinton Rossiter ed., 1961). See generally ALAN BRINKLEY ET AL., NEW FEDERALIST PAPERS: ESSAYS IN DEFENSE OF the Constitution (1997); The Essential Federalist: A New Reading of the Federalist PAPERS (Quentin P. Taylor ed., 1998); Philip C. Kissam, Explaining Constitutional Law Publicly or, Everyman's Constitution, 71 UMKC L. REV. 77 (2002); David McGowan, Ethos in Law and History: Alexander Hamilton, The Federalist, and the Supreme Court, 85 MinN. L. Rev. 755 (2001); Seth Barrett Tillman, The Federalist Papers as Reliable Historical Source Material for Constitutional Interpretation, 105 W. VA. L. REV. 601 (2003). 